\title{
A GÊNESE DA AGRICULTURA E DA SILVICULTURA MODERNA NO ESTADO DE SÃO PAULO
}

\section{MÁRIO ROBERTO FERRARO}

\author{
Dissertação apresentada à Escola Superior de \\ Agricultura "Luiz de Queiroz", Universidade de São \\ Paulo, para obtenção do título de Mestre em Recursos \\ Florestais, com opção em Conservação de \\ Ecossistemas Florestais.
}

\author{
PIRACICABA \\ Estado de São Paulo - Brasil
}

Fevereiro 2005 


\title{
A GÊNESE DA AGRICULTURA E DA SILVICULTURA MODERNA NO ESTADO DE SÃO PAULO
}

\section{MÁRIO ROBERTO FERRARO}

Bacharel e Licenciado em História

Orientador: Prof $^{\mathrm{a}}$. Dr $^{\mathrm{a}}$. TERESA CRISTINA MAGRO

\begin{abstract}
Dissertação apresentada à Escola Superior de Agricultura "Luiz de Queiroz", Universidade de São Paulo, para obtenção do título de Mestre em Recursos Florestais, com opção em Conservação de Ecossistemas Florestais.
\end{abstract}

PIRACICABA

Estado de São Paulo - Brasil

Fevereiro 2005 
Dados Internacionais de Catalogação na Publicação (CIP) DIVISÃO DE BIBLIOTECA E DOCUMENTAÇÃO - ESALQ/USP

\section{Ferraro, Mário Roberto}

A gênese da agricultura e da silvicultura moderna no Estado de São Paulo / Mário

Roberto Ferraro. - - Piracicaba, 2005.

106 p. : il.

Dissertação (Mestrado) - - Escola Superior de Agricultura Luiz de Queiroz, 2005.

Bibliografia.

1. Agricultura moderna 2. Agricultura tradicional 3. Edmundo Navarro de Andrade - História 4. ESALQ - História 5. Ferrovias 6. Proteção ambiental 7. Silvicultura I. Título

CDD 630.9

"Permitida a cópia total ou parcial deste documento, desde que citada a fonte - O autor" 


\section{DEDICATÓRIA}

Dedico este trabalho aos professores que me ensinaram o gosto pela leitura e pela escrita, especialmente a Michael Mac Donald Hall, pela compreensão e generosidade.

Dedico Também aos meus alunos, a quem ensino e com quem aprendo. 


\section{AGRADECIMENTOS}

Agradeço aos professores do Departamento de Ciências Florestais (LCF), especialmente à Profa. Dra. Teresa Cristina Magro e ao Prof. Dr. Marcos Sorrentino pela dedicação e apoio. Aos Professores Doutores Demóstenes Ferreira da Silva Filho, Carmem Lúcia Rodrigues (Calu) e Mário Ferreira agradeço também pelas sugestões e correções.

A todos que me acolheram com amizade e generosidade e a todos que de alguma forma contribuíram para a realização deste estudo.

Aos funcionários do LCF, em especial a Catarina. Aos funcionários da Biblioteca da ESALQ, que me ajudaram a procurar livros esquecidos pelo desuso em prateleiras pouco visitadas. Às funcionárias da Biblioteca do Instituto Agronômico de Campinas, onde passei a maior parte do tempo e por vezes atrasando seus horários de saída. Em ambas fui atendido com presteza e eficiência.

À Comissão de pós-graduação da Universidade Estadual de Goiás por me permitir um afastamento remunerado por dois anos, o que tornou este estudo possível.

Aos meus irmãos. Eles sabem o porquê. 


\section{SUMÁRIO}

LISTA DE FIGURAS

Página

LISTA DE TABELAS vii

LISTA DE ABREVIATURAS …............................................................... ix

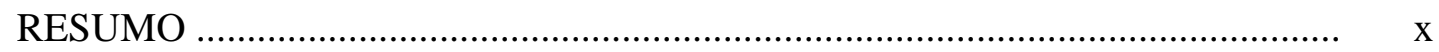

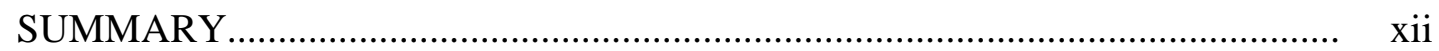

1 INTRODUÇÃO ................................................................................... 1

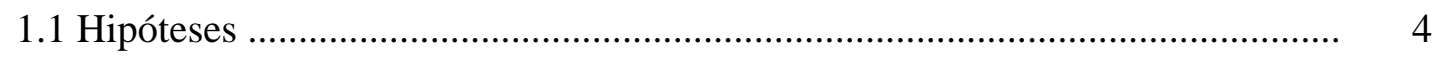

2 REVISÃO DE LITERATURA........................................................................ 6

2.1 Caracterização do período de 1870 a 1914 ....................................................... 6

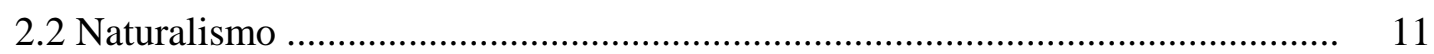

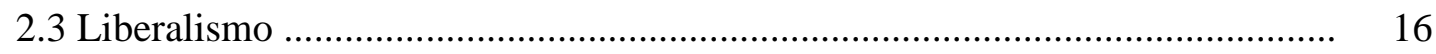

2.4 Revolução sanitária ...................................................................................... 21

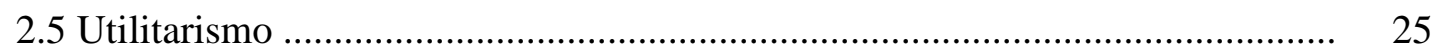

2.6 Outras considerações ..................................................................................... 34

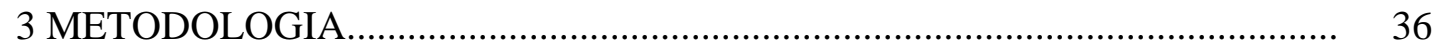

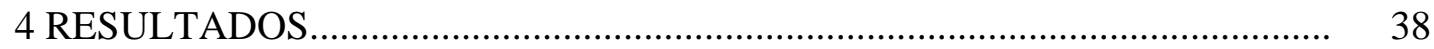

4.1 A agricultura tradicional ............................................................................ 38

4.2 A agricultura moderna.................................................................................. 4

4.2.1 A Gênese da modernização da agricultura em São Paulo ............................... 47

4.2.2 Experiências modernizantes no início do século XX .................................... 54

4.2.3 A modernização: algumas reflexões ............................................................ 55 


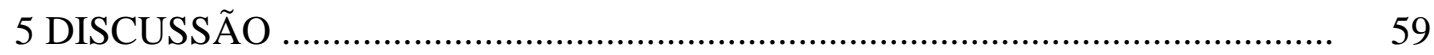

5.1 A modernização da agricultura no governo de Jorge Tibiriçá (1904-1908) ... 59

5.1.1 Distribuição de mudas e sementes ............................................................. 61

5.1.2 Propaganda agrícola ................................................................................. 61

5.1.3 Campos de Experiência e de Demonstração.................................................. 63

5.1.4 Horto Agrário Tropical, em Cubatão ............................................................. 64

5.15 Instituto Agronômico de Campinas .............................................................. 65

5.1.6 Horto Botânico ....................................................................................... 66

5.1.7 Posto Zootécnico Central...................................................................... 66

5.1.8 Serviço Meteorológico ............................................................................. 67

5.1.9 Galeria de Demonstração de Máquinas ......................................................... 67

5.1.10 Terras devolutas e colonização do território .................................................. 68

5.2 A ESALQ na gênese da agricultura científica. ................................................. 73

5.2.1 O projeto de modernização da agricultura expresso em arte........................... 78

5.3 A educação do cidadão para a nova agricultura................................................. 85

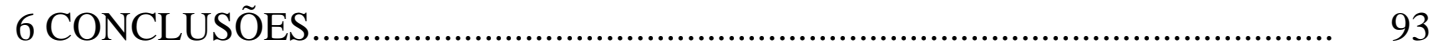

REFERÊNCIAS BIBLIOGRÁFICAS _............................................................... 98 


\section{LISTA DE FIGURAS}

Página

1 A Exportação de café no Porto de Santos ................................................................. 78

2 O Porto de Santos e a intensa atividade de carregamento do café, por carroças e principalmente por ferrovia

3 Vitral na escada que conduz ao Salão Nobre da ESALQ retratando a principais símbolos da agricultura da época 80

4 Mural dos formandos de 1910 (Detalhe) ............................................................... 81

5 Mural dos formandos de 1915........................................................................... 82

6 Mural dos formandos de 1908 ......................................................................... 83

7 Mural dos formandos da ESALQ de 1916 (Detalhe)............................................. 84

8 Mural dos formandos da ESALQ de 1916 (Detalhe)............................................... 85 


\section{LISTA DE TABELAS}

Página

1 Distribuição do Boletim Agrícola (1904) 


\section{LISTA DE ABREVIATURAS}

Cia - Companhia

ESALQ - Escola Superior de Agricultura Luiz de Queiroz

IAC - Instituto Agronômico de Campinas

LCF - Departamento de Ciências Florestais

SPA - Sociedade Paulista de Agricultura 


\title{
A GÊNESE DA AGRICULTURA E DA SILVICULTURA MODERNA NO ESTADO DE SÃO PAULO
}

\author{
Autor: MÁRIO ROBERTO FERRARO \\ Orientadora Prof. Dra. TERESA CRISTINA MAGRO
}

\section{Resumo}

A modernização da agricultura e o surgimento da silvicultura em sua gênese no início do século XX, no Estado de São Paulo, são abordados e analisados nesta pesquisa. Nossa hipótese é a de que a elite agrária, incluindo Edmundo Navarro de Andrade, considerado um ícone da silvicultura no país, possuía um projeto de modernização da agricultura que se servia de modelos europeus e norte-americanos. Podemos dizer que a elite agrária se impõe ao país porque tinha uma proposta política consistente, bem fundamentada cientificamente, atualizada em relação a outros países e articulada com outros setores da sociedade, tais como os políticos e a mídia, principalmente. São apresentados fatos que mostram que a modernização da agricultura foi um processo mundial, que o Brasil nela se insere elegendo a Europa como modelo intelectual e os Estados Unidos como exemplo concreto a ser imitado em suas realizações, sendo a Sociedade Paulista de Agricultura (SPA) a principal incentivadora no Estado de São 
Paulo. O governo de Jorge Tibiriçá (1905-1908), cujo secretariado era composto em sua totalidade por membros oriundos da SPA, foi seu primeiro implementador. Esta pode ser considerada a primeira experiência de aplicação da ciência como norteadora de uma política pública bem definida em relação à agricultura. A ferrovia é o principal agente da modernização no campo ao permitir a agricultura avançar para além de duzentos quilômetros do litoral e ao permitir a circulação de mercadorias, pessoas e idéias. Faz parte da agricultura moderna: o uso de princípios científicos e tecnologias na organização do trabalho agrícola; a diversificação da agricultura; a implantação de colônias para fixar o colono à terra, tornando-os pequenos proprietários; a pesquisa agrícola para produção ou adaptação de novos conhecimentos e o ensino agrícola - a reformulação da Escola Superior de Agricultura Luiz de Queiroz (ESALQ) é a grande realização deste governo. Navarro se insere neste processo desde o seu retorno ao Brasil após conclusão dos estudos na Europa, em 1903, produzindo conhecimento de natureza teórico-prático em diversos ramos da agricultura moderna, mas se sobressai ao implantar nos Hortos da Cia Paulista de Estradas de Ferro a silvicultura moderna para suprir a demanda de lenha e acalmar os críticos que a acusavam de destruir florestas numa velocidade vertiginosa. O encantamento geral despertado pela figura de Navarro se deve ao fato de os níveis de excelência alcançados em suas experiências muito tempo depois ainda não haviam sido superados. Entretanto, como conservacionista, podemos quando muito argumentar que nem mesmo na Cia Paulista de Estradas de Ferro sua empreitada foi satisfatória, pois ela nunca conseguira produzir mais de quarenta por cento da lenha que consumia, ou seja, mesmo com um "mar de eucaliptos" ainda continuava consumindo árvores e florestas naturais inteiras. 
THE GENESIS OF FORESTRY AND MODERN AGRICULTURE IN SÃO PAULO STATE

Author: MÁRIO ROBERTO FERRARO

Adviser Prof. Dra. TERESA CRISTINA MAGRO

\section{SUMMARY}

The modernization of agriculture and the emergence of Forestry in its genesis in the beginning of the Twentieth Century in the State of São Paulo are approached and analyzed in this work. The hypothesis is that the agrarian elite, including Edmundo Navarro de Andrade, considered an icon in Forestry in Brazil, possessed a project for the modernization of agriculture, which used European and North American patterns. We can state that the agrarian elite enforces itself in Brazil because it had a firm political proposal, well-based scientifically and updated compared to other countries and wellrelated to other sectors of the society, such as politicians and the media above all. Facts are presented showing that the modernization of agriculture is a worldwide process, in which Brazil follows Europe for an intellectual pattern and The United Sates of America as a concrete example to be imitated in its accomplishments, and the "Sociedade Paulista de Agricultura” (SPA) the main supporter in the State of São Paulo. The government of Jorge Tibiriçá (1905-1908), whose secretaries were in its majority members of the 
"Sociedade Paulista de Agricultura” (SPA), was its first supporter. This was the first experience of science application as a guide for a well-defined public politics regarding agriculture. The railroad is the main agent for the modernization of the fields, allowing the agriculture move more than two hundred kilometers from the seacoast and making the circulation of products, people and ideas possible. It is part of modern agriculture the use of scientific principals, technology in the organization of the agricultural work, the diversification of agriculture, the implantation of colonies to locate the farmer to the land, making them small land owners; the agricultural research for the production or adaptation of new knowledge and the agricultural teaching - the reformulation of the "Escola Superior de Agricultura Luiz de Queiroz (ESALQ) is the great accomplishment of this government. Navarro participates in this process since his return to Brazil, after having concluded his studies in Europe in 1903; producing theoretical/practical knowledge in different sections of agriculture, but he excels when he implants Modern Forestry in the "Hortos da Companhia Paulista de Estradas de Ferro", to supply the wood demand and calm down the critics that accused it of destroying forests in a wild speed. The general enchantment provoked by Navarro is due to the fact that the levels of excellence achieved in his experiments had not been surpassed after a long time. However, as a conservative, we can affirm that not even in the "Companhia Paulista de Estradas de Ferro" his work was satisfactory, for this company would never be able to produce more than forty percent of the wood it consumed, that means, even with a "sea of eucalyptus” it still devoured entire natural trees and forests. 


\section{INTRODUÇÃO}

O objetivo inicial desta pesquisa era fazer uma biografia intelectual de Edmundo Navarro de Andrade. Começamos fazendo um amplo levantamento de seus livros e artigos publicados na Revista Agrícola, n’O Fazendeiro e no Boletim da Agricultura. Foram estudados muitos artigos publicados e constatado que ele travava uma luta incessante pela modernizarão da agricultura, em favor da chamada agricultura racional, pois fazia experimentos não só com reflorestamento, mas com café, forragens, adubos, inseticidas, máquinas, apicultura, citros, uso de dinamite na agricultura. Entretanto, havia dificuldade em perceber qual tipo de agricultura Navarro combatia. Afinal, o que era a agricultura tradicional? Por que ela precisava ser combatida? Quem era contra ela? Quais forças sociais eram favoráveis a ela? Esta definição foi muito difícil de ser constatada, pois há uma enorme confusão acerca deste conceito e também do conceito de agricultura moderna. Pareceu relevante trabalhar esses dois conceitos para poder entender a obra de Navarro. Então foram iniciadas as leituras das obras dos historiadores que pesquisaram o período chamado Belle Époque, que vai de 1870 a 1918, aproximadamente, tais como Nicolau Sevcenko, Roberto Ventura, Luciana Murari, para definir as principais características do período e verificar se elas estavam presentes na obra de Navarro.

Nestes autores, para compor o referencial teórico, buscou-se algumas categorias de análise que permitissem selecionar, organizar e interpretar as fontes históricas. Estas categorias são: darwinismo, racialismo, utilitarismo, evolucionismo, liberalismo e outras que ainda não foram explicitadas.

Porém, com o avançar das pesquisas, notou-se que Navarro fazia parte de um movimento social mais amplo, articulado na SPA - Sociedade Paulista de Agricultura, e 
divulgado pela Revista Agrícola, em favor da modernização da agricultura como forma de superação da crise de superprodução em que se encontrava a produção agrícola do estado, gerada pelo plantio exagerado de café em anos anteriores. Percebeu-se que este movimento é anterior a Navarro, que vinha se gestando desde 1900 e que transcende em muito o alcance de sua obra. A SPA pretendia mudar a face da agricultura do Estado e, quiçá, do Brasil. Navarro, por sua vez, implantou a silvicultura moderna, talvez a primeira do país, - com exceção da Floresta da Tijuca -, para atender às necessidades de lenha combustível da empresa onde trabalhava, a Cia Paulista de Estradas de Ferro. Ou seja, estudar a gênese do processo de modernização tem uma relevância maior que a obra de Navarro, em função de ser a modernização da agricultura a questão central do debate sobre o campo da época e em função da necessidade de se eliminar a confusão que se faz atualmente a respeito deste conceito, pois muitos pensam que um arado puxado à tração animal ou estrumação são práticas da agricultura tradicional.

Também foi objetivo desta pesquisa produzir um material adequado aos estudantes, no qual a história do processo de modernização fosse exposta numa linguagem clara e acessível, pois percebemos haver entre os estudantes grande confusão acerca destes conceitos, principalmente no que se refere à agricultura tradicional. Eles desconsideram as relações sociais como parte do conceito, observando apenas a tecnologia, fazendo confusão entre o obsoleto e o avançado, considerando o obsoleto como sendo tradicional e moderno apenas o avançado, quando na verdade o princípio que rege ambos é o mesmo. O princípio que justifica o uso de um arado puxado por um animal é o mesmo que rege o de um arado puxado por um trator com motor à explosão, que é o de potencializar o trabalho humano, permitindo ao agricultor produzir mais, em um espaço de tempo menor, com o menor desgaste.

A essência do processo de modernização da agricultura era o ensino agrícola, sendo esta a preocupação maior do Governo Tibiriçá, de Carlos Botelho e da Revista Agrícola. É para onde são canalizados muitos esforços, conforme apontam as fontes consultadas. Não levá-las em consideração seria faltar com a verdade e comprometer o valor científico do trabalho, pois nosso objetivo é reconstituir o passado humano, ainda que num recorte espaço/temporal muito pequeno. 
O fato da Escola Superior de Agricultura Luiz de Queiroz (ESALQ) ser um dos pontos mais importantes do projeto de modernização da agricultura pode passar, ao longo do texto, a impressão de um certo tom de auto-elogio, o que não é verdadeiro, pois não foi emitido juízo de valor. Tudo o que se refere à Escola fora retirado das fontes documentais consultadas quase ao final da pesquisa. É importante esclarecer que o estudo adquiriu este suposto caráter de valorização que parece excessivo porque consultamos apenas fontes oficiais, tais como publicações da Secretaria da Agricultura e revistas relacionadas à classe empresarial agrícola, não sendo consultadas fontes relacionadas aos opositores da modernização da agricultura.

A modernização da agricultura está ocorrendo simultaneamente em todos os setores ligados à agricultura, em todas as repartições ligadas à Secretaria, nas fazendas de particulares. O mérito de Navarro é ter tido a oportunidade de fazê-lo no que talvez fosse o maior complexo agroindustrial ${ }^{1}$ de sua época, com uma grande disponibilidade de capital e uma grande possibilidade de acesso às fontes deste saber. Silvicultura para Navarro é também um aprendizado.

Não se deve esquecer que ele volta formado da Universidade de Coimbra como agrônomo, onde defendeu tese de Doutorado sobre como conter dunas nas praias da Gasgonha e que antes de assumir o posto de chefe do Serviço Florestal na Companhia Paulista de Estrada de Ferro publica artigos sobre podas de pessegueiros, sobre o uso de instrumentos de poda e outros, mas não sobre silvicultura. Podemos dizer que ele se constituiu numa autoridade incontestável em eucaliptos durante a execução de um trabalho que também fora um processo de aprendizagem. Esta hipótese pode ser confirmada pela consulta aos referenciais bibliográficos de artigos por ele publicados. Nestes artigos é possível verificar a citação de inúmeros autores especialistas no assunto, bem como de revistas estrangeiras tratando de assuntos ferroviários assinadas pela Cia Paulista. É importante ressaltar ainda as inúmeras viagens de estudos feitas por ele aos Estados Unidos e a outros países.

\footnotetext{
${ }^{1}$ A Cia Paulista de Estradas de Ferro "havia se tornado um complexo agro industrial composto por um conjunto de empresas lucrativas de diferentes ramos - hortos florestais, oficinas mecânicas, frigoríficos, indústrias de papel, colonização, transportes rodoviários, etc” (Bicalho, 1986, p.63).
} 
Navarro certamente pode ser apontado como um dos principais artífices do processo de modernização da agricultura, principalmente porque constituiu e implantou no país uma silvicultura dentro das perspectivas científicas mais avançadas de sua época. O primeiro capítulo desta dissertação procura demonstrar, inclusive, como os pressupostos teóricos que norteiam a produção de sua época estão presentes em sua obra.

No entanto, é imprescindível esclarecer que o mérito intelectual da modernização da agricultura em nosso Estado não é individual, mas coletivo. Muito deve ser creditado à SPA - Sociedade Paulista de Agricultura -, tendo como seus principais mentores Luiz Pereira Barreto e Carlos Botelho. Em nível institucional, sem dúvida nenhuma a ESALQ, o Instituto Agronômico de Campinas, o Posto Zootécnico Central e o Horto Florestal, este mais tarde completamente reformulado por Navarro, foram as instituições que tiveram um papel da maior relevância e que sobreviveram ao tempo, sendo que a ESALQ continua cumprindo até hoje a função que lhe dera Carlos Botelho.

\subsection{Hipóteses}

A primeira hipótese que investigamos é a de que as justificativas científicas de Edmundo Navarro de Andrade para o manejo dos recursos naturais estavam em consonância com os setores mais avançados da sociedade brasileira, ou seja, que ele fazia parte de um projeto mais amplo da vanguarda empresarial para a modernização do país que se servia de modelos europeus e norte-americanos.

Como hipótese geral podemos dizer que Navarro se impôs diante da sociedade brasileira porque tinha uma proposta política consistente, moderna, bem fundamentada cientificamente e atualizada em relação a outros países e politicamente articulada na Sociedade Paulista de Agricultura (SPA).

Porém com o andamento das pesquisas ficou mais claro a necessidade de se definir o projeto modernizador da agricultura como um todo. Ou seja, houve uma ampliação da hipótese, qual seja, a elite agrária do país, incluindo Navarro, possuía um projeto de modernização da agricultura, que se servia de modelos europeus e norteamericanos. 
Pode-se dizer que o setor modernizante da elite agrária se impõe diante da sociedade brasileira porque tinha uma proposta política consistente, bem amparada cientificamente e em consonância com outros países e articulada junto a outros setores da sociedade, os políticos e a mídia, principalmente. 


\section{REVISÃO DE LITERATURA}

\subsection{Caracterização do Período de 1870 a 1914.}

A intenção deste capítulo no início de nossas pesquisas era a de contextualizar a obra de Edmundo Navarro de Andrade e ressaltar que a silvicultura por ele praticada se inseria num processo de modernização que ocorria no mundo inteiro, capitaneado pelas nações européias, principalmente França e Inglaterra, e mais tardiamente, já no início do século XX, pelos Estados Unidos da América. Porém, à medida em que as fontes eram consultadas, ficou óbvio para nós a necessidade de se analisar as circunstâncias em que ocorreu o processo de modernização da agricultura paulista como um todo no início do século XX, sob o governo de Jorge Tibiriçá, tendo como secretário da agricultura o Sr. Carlos Botelho. Cabe destacar a importância que a Escola Superior Luiz de Queiroz teve neste processo, bem como o papel da educação em outros níveis, sob pena de não se conseguir reconstituir o processo histórico. Portanto, o que deveria ser apenas uma contextualização, em função da consulta e análise das fontes históricas produzidas pelos próprios agricultores, tornou-se nosso objetivo principal, que será desenvolvido ao longo de todo o trabalho, que é o de reconstituir a história da gênese da agricultura moderna no Estado de São Paulo segundo as idéias defendidas pela Sociedade Paulista de Agricultura. A modernização da agricultura como apontam nossas pesquisas, se insere num período bem anterior ao que o senso comum costuma situá-la, isto é, em meados dos anos sessenta do século XX, com a chamada Revolução Verde.

Desde o início de nossas pesquisas na Revista Agrícola, nos deparamos com a palavra modernização, porém era difícil entender o que significava, pois aquilo que na época era considerado moderno, tais como o uso de arados movidos à tração animal, 
estrumação, hoje é considerado atrasado, superado, obsoleto. Nossa primeira pergunta vem a ser o que significa ser moderno no final do século XIX? E mais especificamente o que significa ser moderno quando o assunto é agricultura?

Nosso primeiro passo foi buscar na história do período o sentido da expressão ser moderno no campo. Entendemos que ser moderno no campo significava desenvolver um novo tipo de agricultura fundamentada teoricamente nas principais correntes do pensamento político, científico e ideológico do seu tempo, ainda que hoje algumas destas correntes ideológicas nos sejam politicamente incorretas, como o racialismo.

Procuramos, neste capítulo, caracterizar o período que hoje conhecemos como Belle Époque, para poder levantar alguns dos aspectos que condicionavam a produção científica do período, que tem como marco inicial a Lei do Ventre Livre, que na prática significava a abolição da escravatura e o final da Primeira Guerra Mundial, que coloca em cheque os paradigmas da época, com a intenção de posteriormente, no capítulo três, poder caracterizar com mais clareza as práticas da agricultura moderna.

Segundo Sevcenko (2003), o Rio de Janeiro da Belle Époque experimentava uma grande efervescência econômica: principal porto do país, décimo quinto no mundo e terceiro nas Américas, atrás apenas de Nova Iorque e Buenos Aires, o que permitia um elevado volume de comércio exterior e o domínio da navegação de cabotagem com o Norte e Nordeste. Formava o maior entroncamento ferroviário do país, o que a tornava o principal centro exportador do Brasil e o colocava simultaneamente em contato com os mais distantes rincões da pátria. O Rio de Janeiro da época, portanto, era não só a capital política da nação como o seu centro econômico, pois era o mais dinâmico pólo comercial do país; e principal centro financeiro, sede do Banco do Brasil e da maior Bolsa de Valores e também o maior centro populacional, o que o tornava o mais amplo mercado nacional de mão-de-obra e de consumo para a indústria nascente.

O Rio de Janeiro, naquele período, vivia uma febre de obras, pois o antigo cais era acanhado. As ruelas estreitas, recurvas e em declive dificultavam as conexões entre o porto, a ferrovia, os armazéns e o comércio varejista, além de serem inseguras e facilitarem a formação de barricadas em caso de motins políticos. As áreas pantanosas traziam epidemias inextirpáveis. Havia também uma enorme população de gente rude 
plantada bem no seu âmago, vivendo no maior desconforto, imundície e promiscuidade. Tudo isso causava no europeu, de quem se pretendia atrair capitais, medo e insegurança. Era, portanto, preciso acabar com a imagem de cidade insegura.

Em 1904, inicia-se o processo de modernização urbana com a inauguração da Avenida Central e com a instituição da vacina obrigatória. Velhos casarões coloniais transformados em cortiços são demolidos. Amplas avenidas, praças e jardins, decorados com estátuas de mármores são abertos. Os pobres são transferidos para o subúrbio ou para os morros onde formariam favelas. O segundo grande marco desta reforma é a inauguração da Exposição Nacional do Rio de Janeiro, que trouxe a glorificação definitiva dos novos ideais da indústria do progresso e da riqueza ilimitados.

Era também uma época de consumismo desenfreado, do esnobismo em suas versões chic ou smart, conforme a origem (francesa e inglesa), das lojas com tapetes finos, das joalherias elegantes, das Maison para vestir as senhoras distintas. Os pobres foram banidos do centro com a extinção dos cortiços, dos restaurantes populares (as freges), dos vendedores ambulantes. Houve a proibição de se andar em mangas de camisa, com os pés descalços, bem como de atividades oriundas da cultura popular, tais como o violão, o jogo do bicho, o realejo e outras. O centro da cidade e a avenida da praia se tornam redutos da nova classe argentária, concatenada com as últimas novidades vindas do último vapor chegado da França. Os navios europeus não traziam apenas os figurinos, o mobiliário e as roupas, mas também notícias sobre os livros mais em voga, as escolas filosóficas predominantes, o comportamento, o lazer, a estética, tudo enfim que fosse consumível e até as doenças.

O Rio de Janeiro era a capital do arrivismo social provocado pelas novas fortunas que se formaram a partir do encilhamento ${ }^{2}$, a política econômica de Rui Barbosa (1889 e 1891), que desfizera fortunas seculares e arruinara pequenos investidores, mas que

\footnotetext{
"“Encilhamento é o nome pelo qual se convencionou chamar o período da história econômica brasileira que se inicia em 1890, com Rui Barbosa no Ministério da Fazenda do Governo Provisório, e cujas conseqüencias se estendem até 1898. Sobretudo nos anos de 1890-1892, é um período de grande agitação financeira em função da política de expansão do meio circulante, da criação de novas empresas, da queda cambial, em suma , de grande instabilidade econômica” (Perissinotto, 1994, p.118, nota 17)
} 
permitiu o enriquecimento de novos segmentos da classe dominante ligados ao Estado, à indústria, ao comércio, às finanças e serviços.

\begin{abstract}
"No decorrer do processo de mudança política, os cargos rendosos e decisórios - antigos e novos - passaram rapidamente para as mãos desses grupos recém chegados à distinção social, premiados com as sucessivas e fartas ondas de "nomeações", "indenizações", "concessões", "garantias", "subvenções", "favores", "privilégios" e "proteções" do novo governo". (Sevcenko, 2003, p.41).
\end{abstract}

A capital federal com as diversas reformas, portanto, presenciava 0 aburguesamento de seu espaço urbano, ou seja, remodelava seu espaço em função dos interesses da nova classe dominante.

O Rio de Janeiro seria a referência para a modernização do país. Todas as demais localidades deveriam se inspirar nas mudanças ocorridas na capital federal.

Observando a sociedade rural e outros grupos tradicionais, visto sob o ponto de vista cosmopolita do Rio de Janeiro regenerado, onde o tempo era encarado sobretudo como um fator de produção e acumulação de riquezas, o resultado não poderia ser outro: conseguimos nos redimir da imagem de preguiçosos que nos era atribuída pelos estrangeiros. Mas esta redenção, diz Sevcenko (2003), era válida apenas para as grandes cidades. Criou-se então uma oposição: cidade industriosa/campo indolente. É o momento em que se registra na consciência intelectual a idéia do desmembramento da comunidade brasileira em duas sociedades antagônicas e dessintonizadas, devendo uma prevalecer sobre a outra, ou encontrarem um ponto de ajustamento. Diante da sugestão de que a regeneração fora válida apenas para as grandes cidades, cabe a pergunta: o campo, a zona rural, mais especificamente, a produção agrícola, não passara também por um processo de modernização?

Nossas pesquisas em outros tipos de fontes históricas, ligadas às lideranças rurais, nos permitiram, levantar outra hipótese: a mesma burguesia, a cafeeira, que promove a regeneração das cidades, promove também a reorganização do espaço rural dentro da perspectiva do progresso. 
O espaço rural reorganizado sob o novo paradigma, o modernizante, passou a ser entendido como sendo o espaço da produção redefinida cientificamente, da circulação de mercadorias e de pessoas redimensionada, com sua capacidade e velocidade ampliadas e da higiene como instrumento de melhoria direta da qualidade de vida e, portanto, do progresso e da civilização. O café e a ferrovia são os principais vetores de transformação. A plantação de eucalipto, tida como exemplo de atividade que já nasceu sob o signo da modernidade ${ }^{3}$, era uma atividade subsidiária a ambas e traz consigo as mesmas características que marcam as atividades econômicas principais.

Por questões metodológicas fomos induzidos a definir a nossa pesquisa no tempo, conforme já explicitamos, e também no espaço. Daremos enfoque ao Estado de São Paulo, embora a modernização da agricultura tenha ocorrido também no Estado do Rio de Janeiro, Minas Gerais e Rio Grande do Sul. As fontes primárias mais importantes por nós consultadas foram: Boletim Agrícola, Revista Agrícola $e$ O Fazendeiro, sendo as duas últimas porta-vozes oficiais dos fazendeiros paulistas, organizados em torno da Sociedade Paulista de Agricultura.

A revista O Fazendeiro começou a ser publicada em 1908 como sucessora da Revista Agrícola, que deixara de circular em 1907. Ambas eram de circulação nacional, contavam, cada uma em sua época, com um amplo esquema de venda de assinaturas, com representantes em algumas capitais e nas principais estações ferroviárias do interior. A distribuição era feita pela via férrea até as estações e daí em diante pelo chefe da estação, que era também representante dos correios, e se encarregava de fazê-las chegar ao destinatário final, o fazendeiro.

Edmundo Navarro de Andrade, um dos grandes responsáveis pela propaganda da agricultura científica, colabora na Revista Agrícola a partir de 1903 e também n’O Fazendeiro, da qual se torna redator chefe em 1911. Segundo Sampaio (1961), Navarro sempre estivera de alguma forma ligado à imprensa, pois antes de estudar agronomia

\footnotetext{
${ }^{3} \mathrm{O}$ eucalipto fora primeiro introduzido no Rio Grande do Sul em 1868. "No Rio de Janeiro, o Sr. Pereira Fonseca plantou 15 mil árvores em seu bosque particular de 90 mil espécies”. No Estado de São Paulo, os jesuítas os introduziram em Itatiba e o "Dr. Pereira Barreto tem estudado o Eucalyptus e deve ser proclamado o introdutor desta essência neste estado, tendo feito propaganda em seu sítio em Pirituba". (O Fazendeiro, 1922, p.276)
} 
trabalhara como revisor tipográfico em jornal paulista, emprego então de prestígio. Ou seja, é quase certo que deva ter estabelecido contato com grandes jornalistas de então, bem como tido o acesso a muitos textos de qualidade, o que poderia explicar o pleno domínio do uso que ele faz da linguagem de imprensa e facilidade para transformar assuntos técnicos e científicos em linguagem acessível ao público leigo. Pode-se dizer que ele foi um grande comunicador.

Fomos para essas fontes com um olhar já familiarizado com elementos assinalados por Sevcenko como característicos do período, a saber: influência das ciências naturais, com o darwinismo; a revolução sanitária, fruto direto do processo de urbanização, também de forte inspiração darwinista, e a revolução tecnológica. E como fundamento da criação do Estado Nacional, o cientificismo e o liberalismo.

Sevcenko, porém, não pretendia somente resgatar a obra dos dois autores objetos de sua pesquisa, a saber, Lima Barreto e Euclides da Cunha, mas a partir dos elementos fornecidos em seus romances, crônicas, ensaios, artigos de jornais, almejava tornar mais clara a compreensão da história do Brasil no período estudado. Sua pesquisa tem início com a análise do contexto social em que ambos escrevem: o Rio de Janeiro bastante transformado em seu espaço urbano e em seu modo de vida pela vivência no novo regime Republicano.

Na seqüência, apresentaremos um breve sumário desses quatro pontos levantados por Sevcenko, para a caracterização do período em estudo, a saber: o naturalismo, o liberalismo, a revolução sanitária e o utilitarismo. Dentro desse panorama, situamos a figura de Navarro, cujos escritos estão bastante permeados por essas idéias. ${ }^{4}$

\subsection{Naturalismo}

Comecemos pela influência das ciências naturais. Navarro, que estudou agronomia em Coimbra, patrocinado pela Família Prado, mais especificamente por Eduardo Prado, deve ter tido em Portugal os primeiros contatos com as idéias de Darwin, do qual não só era leitor, como também divulgador, embora somente fazendo

\footnotetext{
${ }^{4}$ Embora usaremos Navarro de Andrade como referência, essas idéias estão presentes em todos os intelectuais que defendem a modernização da agricultura.
} 
referência bibliográfica implícita, exceto no libreto Questões Florestais (1915b), onde o The Voyage of a Naturalist é citado.

Em outro artigo, n’O Fazendeiro, retoma Darwin para analisar a importância das matas nas variações climáticas. Numa passagem escreve que a: "leitura de Darwin que não é indigesta, e talvez fizesse bem a muita gente” (Andrade, 1911a, p.472), ou seja, recomenda sua leitura a todos, mas especialmente àqueles com quem polemiza.

Segundo Murari (2002), pode-se resumir as idéias que fundamentam o darwinismo social da seguinte maneira: a natureza humana estaria incluída nos esquemas evolutivos observados entre as espécies animais, participando deles não apenas no que se refere às suas propriedades físicas, mas também no que diz respeito às suas características psicológicas; a pressão do aumento populacional em relação aos recursos disponíveis criaria uma competição entre os organismos para a satisfação de suas necessidades vitais; haveria uma desigualdade fundamental entre os seres e os conjuntos humanos, segundo um determinismo biológico que estabeleceria hierarquias naturais representadas por aptidões físicas e psíquicas desiguais, distintos modos de comportamento e condições específicas de perfectibilidade; no contexto da desigualdade e da competição, determinados traços criariam vantagens e determinariam a sobrevivência dos mais aptos; estes traços seriam transmitidos por herança reproduzindo as desigualdades; novas espécies surgiriam em função dos processos de seleção e herança, enquanto outras seriam eliminadas; a evolução do mundo natural e da sociedade dar-se-ia de acordo com processos seletivos através dos quais os indivíduos e grupos tidos como superiores sobreviveriam aos demais.

Uma das decorrências da aproximação entre o moral e o biológico feita pelos darwinistas é o determinismo racial: os traços físicos de uma raça corresponderiam as suas características morais e sociais, cada uma delas possuiria uma diferente capacidade de desenvolvimento social e cultural, independente da interferência de qualquer valor não biológico. Assim a civilização corresponderia aos caracteres da raça branca e a miscigenação seria uma degeneração, pois introduzia caracteres raciais discrepantes nas raças consideradas superiores. 
A diferença entre a concepção darwinista e outras formas de diferenciação racial está no fato de o racialismo darwinista ser fundamentado teoricamente em métodos científicos e de ser pretensamente neutro e amoral, pois estava no domínio da natureza e não no da moral ou da cultura. Não se apresentava como uma criação humana, mas como sendo algo definido exteriormente à ação humana.

Murari (2002) escreve que Todorov utiliza o termo racialismo por oposição a racismo. Enquanto o primeiro designa um corpo de conhecimento de caráter científico que vincula o movimento da história às determinações raciais, o segundo refere-se a um comportamento amplo que não tem fundamentação científica.

Para Murari (2002), a natureza, segundo a visão darwinista, possui uma dupla acepção: ou é vista como modelo a ser copiado pelas práticas e pelas instituições e pelo conhecimento da sociedade ou como ameaça, algo a ser temido e evitado por meio de recursos apropriados. O primeiro aspecto fora tomado da idéia de se conceber a sociedade como similar a um organismo vivo, analisando os problemas sociais de maneira semelhante ao que ocorre no reino animal, método este que será amplamente utilizado pelas ciências sociais nascentes na segunda metade do século XIX. O outro aspecto da dualidade darwinista é o de se conceber a natureza como sendo uma ameaça e está relacionado ao sentido geral e metafórico de luta pela sobrevivência, certamente tributária da dinamização do pensamento malthusiano operada pela seleção natural. Esta luta pela sobrevivência operaria em três níveis: o primeiro seria a competição intraespécies, a segunda a luta das espécies entre si e o terceiro a luta do conjunto das espécies de um determinado meio e contra as condições de vida dentro deste. A luta pela sobrevivência pode levar ao estabelecimento de relações de dependência, mutualismo e de cooperação entre as espécies para sobreviverem em um meio hostil, mas devido à influência malthusiana a que prevaleceu foi a noção de luta sangrenta.

As questões centrais do darwinismo, a "luta pela sobrevivência” e o “racialismo”, aparecem freqüentemente em Navarro.

A noção de luta pela sobrevivência desponta quando se discute questões referentes à organização da produção, tais como, espaçamento entre as plantas ou numa sementeira para estimular a competição intra-espécie, escolha do terreno para se fazer 
um viveiro de mudas. A esse propósito Navarro recomenda que para a instalação de um viveiro seja escolhido um terreno fértil, pois:

“(...) as plantas nascidas e criadas em terrenos férteis, ricos, são robustas, com raízes numerosas e bem desenvolvidas e, por isso mesmo, como nenhumas outras, resistem melhor em terrenos pobres. (...) Na luta pela vida vencerão sempre os indivíduos mais fortes, possuidores de melhores elementos para lutar". (Andrade, 1904, p.140-141).

Plantas nascidas em terrenos férteis serão mais fortes quando colocadas em terrenos pobres, que são os terrenos historicamente ocupados pela silvicultura, e terão mais força para competir com as plantas já adaptadas àqueles terrenos. O darwinismo torna possível a percepção consciente de processos que hoje nos parecem óbvios, quase que naturais, mas que na verdade demandam uma teoria científica para sua elaboração.

A luta pela sobrevivência das espécies favoráveis ao homem justifica a aplicação de mata-mato ou de formicida para diminuir a competição pela vida entre as espécies desejáveis ao homem e aquelas que devem morrer, as chamadas ervas daninhas ou insetos predadores.

O racialismo é também amplamente utilizado por Navarro para explicar determinados fenômenos sociais. Entretanto, quando esses conceitos oriundos das ciências naturais são aplicados às ciências sociais acabam por conduzir a uma visão da história como um processo evolutivo cuja meta final é o progresso material quase que ilimitado destinado a satisfazer as necessidades humanas ou, ao menos, as necessidades do capital. Nesse processo a Europa, mais particularmente a França, apresenta-se como sendo o centro irradiador destas concepções. O europeu era considerado uma raça superior capaz de levar os progressos a outros povos vistos como atrasados e inferiores, o que justificaria a presença européia nas áreas colonizadas.

Em Navarro (1927), a concordância com essas idéias é bastante clara. Nos seus relatos de viagens, mais tarde reunidos no livro Por ahí Além, ao comentar sobre hábitos e costumes de outros povos a visão de inferioridade que se tem a respeito deles fica evidente. Nas crônicas da coletânea, o autor, por exemplo, comenta que o povo malaio tem "proximidades com os macacos" (p.30); chama os japoneses de "idiotas" e 
que o Brasil "é o único país do mundo onde são considerados gente"; fala ainda em "patifaria” como sendo uma característica da raça armênia (p.51).

Há um parágrafo onde o autor comenta suas concepções a respeito da questão racial, que optamos por transcrever integralmente.

“(...) eu deveria ter até uma certa quisilia aos hespanhoes, pois que a má vontade, a antipathia a certas raças e povos se encontra justamente mais acentuada em seus descendentes. Verdade seja que no tocante aos portugueses, estou firmemente convencido de que se explica por terem elles, na falta de boa matéria prima se utilizado da prata da casa que, naqueles tempos, ou era o "cobre” africano ou o bronze de nossas selvas sem ligarem a devida importância à côr das "consequencias”. Não é branco quem quer dahí essa raiva toda. Um caracuista ${ }^{5}$ nunca perdoará que lhe mettam sangue zebu na manada" (Andrade, 1927, p.64).

Navarro, que era descendente de europeus, "mestiço" de português e espanhol, atribui seu racismo, ou má vontade e antipatia a certos povos, à influência espanhola, na qual parece haver uma predisposição natural contra certas raças. Mas ele se pergunta qual é a razão da herança do seu mal-estar relacionado às outras raças provindos de sua origem portuguesa, ou do seu sangue português. Em outras palavras, como se explica o racismo originário de seu lado português? Atribui o autor o racismo português à miscigenação, que era entendida historicamente como um fator circunstancial, uma necessidade devido à falta de mulheres brancas, o que porém interfere na natureza do homem europeu no Brasil ao tornar o sangue português impuro, portanto inferior, isto é, carregado ou contaminado com as imperfeições das raças inferiores, objeto da raiva toda dos puros. Podemos observar que existe uma crença em se atribuir valores e conceitos, notadamente o de raça, como sendo adquiridos por herança genética, ou seja, sua indisposição para com certas raças era natural, por isso amoral, estava no campo da natureza, não da cultura.

\footnotetext{
${ }^{5}$ Caracuista era a denominação dada aos fazendeiros que preferiam gado bovino da raça Caracu em detrimento do Zebu, que estava então sendo introduzido em larga escala no país.
} 
Navarro também se mostra racialista ao qualificar os trabalhadores nacionais como boçais ${ }^{6}$, como incapazes de realizarem certos trabalhos, ou quando revelam ignorância a respeito de determinados assuntos. Aliás, podemos notar que Navarro não se mostra em sua obra como sendo um entusiasta da educação. Não encontramos um único capítulo de algum livro dele ou artigo publicado na imprensa falando sobre a educação dos menos favorecidos. Mesmo em se tratando do ensino de agronomia, localizamos somente um artigo de Navarro de Andrade (1903a), no qual propõe que a reforma pretendida para a Escola Superior de Agricultura Luiz de Queiroz tenha como modelo a Escola Nacional de Agricultura de Coimbra em Portugal. Então ficamos a pensar se o fato deste assunto não estar em sua pauta de preocupações não se deveria ao fato dele acreditar ser impossível de se educar este povo pobre e mestiço.

A mesma má vontade no que diz respeito aos povos inferiores é sentida como simpatia e admiração aos povos superiores, particularmente a França, Inglaterra e Estados Unidos.

Estes conceitos estão presentes em quase todos os autores do período. Somente com a publicação de Casa Grande e Senzala, de Gilberto Freire, em 1918, novos paradigmas começarão a ser estabelecidos e questões como raça, miscigenação, democracia racial serão tiradas dos domínios da natureza e passarão a serem entendidas como questões culturais, portanto como criações humanas passíveis de transformação.

\subsection{Liberalismo}

Navarro estudou no colégio militar no Rio de Janeiro, porém, antes de se formar fora expulso por indisciplina ao participar de um motim de conteúdo político, fato ainda obscuro em sua biografia. Lá deve ter tomado os primeiros contatos com o liberalismo político. Também, posteriormente, já de volta a São Paulo, convivia com uma elite política quase toda bacharelada em direito pela Faculdade de Direito do Largo São

\footnotetext{
6 “(...) é necessário um trabalho insano, forte e tenaz para vencer a ignorância dos nossos trabalhadores, mostrando-lhes que a adição de água em nada enfraquece o formicida. Daqui vem, sem dúvida, a causa principal de insucesso desse e de outros produtos à venda no mercado para este fim ”. (Andrade, 1915a, p.149).
} 
Francisco. Segundo Sevcenko (2003) a militância republicana paulista se fez sempre pela linha do mais amplo, declarado e rigoroso apego aos postulados do liberalismo clássico.

O liberalismo de Navarro se opunha às intervenções do Estado na economia e defendia a livre concorrência e o predomínio das leis de mercado.

Navarro tem forte influência do liberalismo norte americano, pois é grande, em sua obra, o número de citações à Constituição e as legislações específicas daquele país, que priorizam em seu conjunto a argumentação em favor dos direitos individuais, entendidos principalmente como sendo direito à propriedade.

No seu Utilidade das Florestas, Navarro de Andrade (1912a) explicita a grande influência que sofrera dos Estados Unidos da América. Procura demonstrar que naquele país há uma legislação específica de proteção à natureza em nível federal, mas que nenhum estado da Federação Americana legislou a respeito. Há apenas leis no sentido de se coibir incêndios por ocasião da derrubada da madeira, ou seja, leis que defendem a propriedade da floresta de modo que a sua extinção não cause prejuízos financeiros ao proprietário. A concepção em voga é de que as matas precisam ser protegidas contra os incêndios para que seu proprietário possa usufruir dela enquanto recurso natural.

Referindo-se ao Brasil, mas influenciado pelo liberalismo norte americano, argumenta enfaticamente que o Estado não pode intervir numa propriedade particular, impedindo que um fazendeiro corte suas matas, causando-lhe prejuízos:

"Obrigar um proprietário a conservar sua matta, impedindo-o de explorá-la como bem entender é vexatório, violento e brutal" (...) "Uma derrubada traz lucros que o governo não pode impedir que sejam conseguidos" (Andrade, 1912a, p.101)

Caso o governo queira se responsabilizar em nível de legislação terá também de arcar com os custos da preservação, argumenta Navarro: "Quererá o governo pagar-lhe a vigilância, guarda e conservação de suas mattas?" (Andrade, 1912a, p.96). 
Numa conferência em Piracicaba, citada por Navarro, Rodolf von Ihering, então chefe do Museu Paulista, pede "(...) que haja mais restrição que impeça o homem, aqui como em outros países de derrubar matas, embora se trate de sua propriedade, sem licença especial de suas autoridades". Navarro replica com eloqüência, "seja embora o nosso o único [protesto] ${ }^{7}$, mas que se saiba que há no pais [alguém] que tem pela liberdade um culto e que por ela lutará sempre" (Andrade, 1912a, p.95). Também se posiciona contra a criação de um Código Florestal, que iria disciplinar a derrubada das matas, "códigos lembram leis, posturas e essas só servem para cercear, restringir a liberdade, sendo, no caso presente, um atentado ao direito de propriedade" (Andrade, 1912a, p.95).

Na época, a posição do diretor do Museu Paulista com relação à natureza se aproximava do que hoje nós podemos chamar de "preservacionista”. Ele recomendava que o estado comprasse áreas com vegetação natural intacta com finalidades de preservação tal qual ela era, não somente preservação da flora, mas também da fauna, e às destinasse ao conhecimento das gerações futuras como um testemunho da natureza virgem, bem como para servirem de campo de estudo para a pesquisa científica, entendida por ele de maneira clássica, ou seja, identificar e classificar a grande diversidade de espécies existentes em nossas florestas. Ele próprio comprou uma dessas áreas próxima à Serra do Mar e a transformou na primeira reserva de proteção ambiental do país e a manteve como propriedade particular até 1910, quando a transferiu para o Estado. Hoje pertence ao Instituto Biológico, da Universidade de São Paulo, com o nome de Reserva do Alto da Serra. Por hora podemos dizer que são duas maneiras diversas de se conceber a natureza: uma em favor da propriedade particular acima de tudo e entendendo a floresta como recurso econômico a ser explorado e a outra preocupada em criar meios legais de conservação. Ou seja, a primeira amplamente liberal no sentido de se respeitar o direito de propriedade e a segunda em favor da intervenção do Estado na preservação da Natureza.

\footnotetext{
${ }^{7}$ Colchetes inseridos pelo autor para facilitar a leitura.
} 
Para Navarro qualquer tipo de intervenção do Estado era inadmissível, pois feria seu ideal de Liberdade. Ele vai repetir esse argumento por toda a sua vida sempre que alguém propor qualquer medida para restringir o corte de árvores, proteger artificialmente a indústria, ou até mesmo em relação à lavoura cafeeira, pois protestava contra as medidas protecionistas adotadas no Convênio de Taubaté em 1906, embora ele mesmo tenha reconhecido que foram bem sucedidas. Por exemplo, em 1912, o Ministro da Agricultura determinou que nas obras do Ministério fossem usadas apenas madeiras nacionais. Navarro protesta com veemência por que "d'aqui para o lançamento de impostos proibitivos para madeiras exóticas vai apenas um passo" (Andrade, 1912b, p.80). Estes impostos se constituiriam num obstáculo para a importação de madeiras que apesar de beleza e qualidades inferiores chegam até nós com preços inferiores. A restrição à importação de madeiras poderia elevar o preço das madeiras nacionais por falta de competidores no mercado. Navarro, na verdade, estava defendendo a empresa onde trabalhava e a compra da madeira mais barata.

Podemos afirmar com segurança que sua defesa do liberalismo está relacionada à postura da Revista Agrícola, que em editorial assinado por Barreto (1903), adota como diretriz política da Sociedade Paulista da Agricultura, entidade de classe dos agricultores, a imitação do modelo agrícola norte-americano que privilegia a livre iniciativa e o mercado aberto, com pouca interferência do Estado, deixando bem claro qual seria a competência deste.

A Companhia Paulista de Estradas de Ferro, da qual Navarro era chefe do serviço Florestal, é organizada segundo o modelo das ferrovias americanas, cujas revistas de propaganda são lidas e divulgadas pelos veículos de comunicação da classe empresarial. Sem falar nas constantes viagens de Navarro ao exterior, principalmente a de 1908 aos EUA, da qual resulta o livro A cultura do Eucaliypto nos Estados Unidos, lançado em 1910, que nada mais é do que um manual de técnicas de plantação de eucaliptos e veículo de propaganda dessa cultura, distribuído gratuitamente aos fazendeiros ao longo da ferrovia pela empresa que patrocinou a sua viagem de estudos e a edição dos seus 
resultados. A defesa da livre iniciativa muito provavelmente fora enormemente reforçada por estas leituras e viagens.

Podemos concluir que a defesa que Navarro faz do liberalismo, bem como a compreensão do papel do Estado na economia e na defesa do cidadão, era uma atitude da classe a qual pertencia e para a qual trabalhava como gerente e em favor da qual militava, isto é, a classe formada pelo grande capital cafeeiro e sua vanguarda representada no Estado de São Paulo pela Sociedade Paulista de Agricultura.

O liberalismo de Navarro, entretanto, tinha suas limitações. Ao assumir o Serviço Florestal do Estado de São Paulo transforma aquele órgão num grande centro de distribuição de mudas de eucalipto para as empresas, o que não deixa de significar uma intervenção do Estado na economia. O Serviço Florestal de São Paulo passa a dedicar-se quase que exclusivamente à produção de mudas de eucaliptos para as empresas ${ }^{8}$ em detrimento do atendimento das necessidades de outros setores da sociedade, como os fruticultores, por exemplo.

Os engenheiros brasileiros do início do século eram considerados pessoas de grande prestígio - e os agrônomos estavam começando também a ocupar um lugar semelhante $^{9}$ - porque eram considerados portadores do progresso, verdadeiros agentes civilizadores, os responsáveis pelos grandes marcos visíveis do progresso. São considerados agentes de transformação social porque dominavam as armas (as técnicas) capazes de subjugar a natureza considerada invencível. Podemos concluir, de acordo com Castro, que todos eles:

"sofreram uma influência significativa das idéias em voga na Europa durante o século XIX. O positivismo e o evolucionismo, mesclados a um liberalismo, mesclados as circunstâncias locais impregnavam a atmosfera intelectual e moral da época,

\footnotetext{
${ }^{8}$ Em 1911 o serviço florestal do Estado de São Paulo distribuiu um total de 250.141 mudas de árvores, das quais 228.969 eram de eucaliptos. (Sixt, 1912, p.40).

“Em 1920 foram distribuídas 1.577.865 mudas, sendo 1.517 .865 de essências florestais e 59.961 de frutíferas (...) [Informa também] que este serviço continua a distribuir mudas aos lavradores do Estado, mediante módica remuneração e gratuitamente às câmaras municipais, repartições públicas e a estradas de ferro que fazem o transporte gratuito de mudas.” (O Fazendeiro, 1921, p.149).

${ }^{9}$ Navarro fala que os agrônomos estão sendo mais valorizados e que "Felizmente (...) nossas propriedades agrícolas começam a serem dirigidas por quem de direito". (Andrade, 1911b, p.88).
} 
fornecendo-lhes o instrumental teórico com o qual pretendiam analisar e transformar a sociedade" (Castro, 1993, p.77-78).

Podemos concluir que não somente Navarro, mas toda a elite intelectual comprometida com a República e com o progresso pode ser considerada liberal, isto é, lançaram mão do liberalismo como instrumental teórico para a transformação da Sociedade.

\subsection{Revolução Sanitária}

O café e a ferrovia são elementos civilizadores e recriadores do espaço rural. E são também elementos de higienização entendida como uma característica do processo de civilização.

Escrevendo sobre a construção da Estrada de Ferro Noroeste do Brasil, Castro, mostra que:

"o que se desejava destacar e imprimir na mente de todos era o
aspecto multiplicador das ferrovias, capazes de desencadear um
processo de desenvolvimento nunca visto no Brasil. O movimento
e a velocidade, intrínsecos aos trens, deveriam fazer mais do que
conduzir celeremente mercadorias e pessoas: sua influência se
espraiaria por todas as atividades dos homens." (Castro, 1993,
p.73-74)

A ferrovia assume desta forma um papel de agente disciplinador, responsável por mudanças que se operariam em todos os níveis da atividade humana. Ela seria, sem trocadilho, o veículo das mudanças. A partir dela se esperaria que os homens tomassem novas atitudes, enfim que desse lugar a um homem novo.

Para Lessa, a ferrovia faz parte de um processo de modernização que ao:

"construir uma imagem de "desenvolvimento" e "progresso", impulsiona as reformas urbanas e sanitárias e dirigi-se para o aparelhamento técnico da "sociedade brasileira" voltando-se para a relação campo/cidade (...) Projetos e estratégias serão 
importantes para a construção da imagem de um Brasil como um País soberano: urbanização, infra-estrutura, integração territorial, controle e hegemonia administrativa do Estado" (Lessa, 1993, p.124).

Navarro num tom profético anuncia que:

"a região atravessada pela Estrada de Ferro Noroeste do Brasil, somente será saneada depois de grandes derrubadas nas suas matas, como as que se fazem ali para plantações de café e como se poderá verificar dentro de poucos anos” (Andrade, 1912b, p.268).

A concepção presente nessa fala é a de que as matas são vetores de doenças, nelas estão abrigados males terríveis que ameaçam a vida do homem e que, portanto, precisam ser extirpados, e na impossibilidade de fazê-lo, recomenda-se a derrubada da mata. Como é sabido hoje, o vaticínio se cumpriu e a região da Noroeste não apresenta mais problemas de saneamento tal como os que se apresentavam na construção da ferrovia e pouco sobrou das matas de antigamente.

Medo das doenças, esse era um dos terrores que a velha estrutura urbana herdada do Império inspirava nos europeus dispostos a investir aqui porque as "áreas pantanosas faziam da febre tifóide, impaludismo, varíola e febre amarela, endemias inextirpáveis” (Sevcenko, 2003, p.41). Se essa é a imagem que temos das cidades, na zona rural, não deveria ser diferente, senão pior.

O Jeca Tatu, personagem de Monteiro Lobato, retrato pessimista de nosso homem do campo, que parecia estar eternamente condenado à miséria, é sobretudo um homem doente, portador de verminoses, anemia e outros males, frutos de uma alimentação incorreta e de falta de medidas de higiene. O texto, publicado no romance Urupês, condenava boa parte da população brasileira de forma inexorável e parecia demonstrar a inviabilidade do progresso no Brasil.

Entretanto, anos mais tarde, Lobato se arrependerá de sua criação, promoverá a reabilitação do Jeca. Este será curado pelas medidas advindas da medicina higienista, que lograva naquele momento identificar alguns dos agentes patológicos que medravam 
nos sertões brasileiros. Lobato ao comentar sobre os trabalhadores de uma plantação de arroz no Vale do Paraíba, na qual os monges proprietários não podiam contar com imigrantes, diz que eles resolveram empregar trabalhadores nacionais, mas antes disso deram-lhes uma alimentação nutritiva e abundante e os instalaram em casas higiênicas e salubres:

"Resultado: uma ressurreição.

Das carcaças opiladas onde morrinhava a indolência do pobre Jeca Tatu, saiu, pelo equilíbrio alimentar, um homem resistente; pela cura das mazelas um homem ativo; pela noção de relativo conforto; um homem sedentário, que "parava" nas fazendas $e$ criava amor à faina agrícola.

As faculdades cerebrais, beneficiando-se logo com os reflexos da saúde, foi possível ensinar-lhes as mil coisas necessárias a um bom operário; foi possível discipliná-los; foi possível adaptá-los ao maquinário agrícola” (Apud: Murari, 2002, p.400).

Os médicos no século XIX tinham um prestígio semelhante ao dos engenheiros na mesma época: eram portadores de um conhecimento que se traduziria em mudanças sociais no sentido da melhoria da qualidade de vida.

Segundo Murari (2002), citando Lugembul, a partir do século XIX europeu, o higienismo começou a organizar-se de forma mais definida, com a adoção de práticas de saneamento urbano, do equipamento das cidades, do abastecimento de água e criação de redes de esgoto e da pesquisa científica da origem das doenças e epidemias. A mesma autora apoiada em Hochman mostra que o higienismo, entretanto, constantemente extrapolou o estudo e o combate das doenças ao apresentar propostas de reorganização da sociedade, sobre a qual procurou exercer uma ação normatizadora.

O higienismo no período por nós estudado era fortemente presente no Brasil, pois as epidemias grassavam pelas cidades e exigiam soluções urgentes. As epidemias de febre amarela em Campinas, SP e Vassouras, RJ, importantes centros cafeeiros, a de peste em Santos e outras, mobilizaram a sociedade em favor de medidas de higiene. 
Entretanto, elas nem sempre foram bem vindas, chegando a ocasionar uma revolta no Rio de Janeiro, conhecida como Revolta da Vacina.

O higienismo exerce uma importante influência nos adeptos do eucalipto enquanto planta importante para o homem. O eucalipto para Navarro tem um papel importante enquanto árvore que contribui para o saneamento, pois promove o "enxugo" do solo, sendo que "as raízes das árvores, estendendo-se até as camadas mais profundas do solo estabelecem verdadeiros drenos, fazendo baixar o lençol de água" (Andrade, 1912b, p.266). Esse “secamento dos terrenos” mais tarde será duramente criticado pelos ambientalistas, que acusarão a monocultura do eucalipto como sendo a responsável pelo ressecamento de áreas agricultáveis.

Os eucaliptos, diz Navarro, "têm sido comparados a verdadeiras bombas, que pela enorme absorção de suas raízes, quer pela extraordinária evaporação de suas folhas" (Andrade, 1912b, p.267), assim retirando a umidade do solo acabam com as condições favoráveis a proliferação dos mosquitos. Antigamente acreditava-se que as árvores de eucaliptos tinham poder saneador:

"pelos obstáculos que ofereciam à marcha dos ventos carregados de miasmas paludosos; hoje porém está perfeitamente demonstrado que sua influência sobre a salubridade de certas zonas é devida ao fato de fazendo desaparecer das superfície a humidade excessiva, destruírem o meio próprio e indispensável para a proliferação dos mosquitos." (Andrade, 1912b, p.267).

Dessa forma somos colocados diante de um dilema, a floresta nativa é ruim para a saúde dos homens e a floresta plantada é boa, ou seja, mais uma vez cabe frisar, café e ferrovia são os portadores do progresso na área sanitária porque, ao transformarem a natureza promovendo a derrubada das matas trazem consigo o bem estar aos homens e a promessa de um futuro melhor porque elimina o meio próprio e indispensável para a proliferação dos mosquitos. O eucalipto, a floresta plantada, do ponto de vista da higiene é mais benéfica ao homem do que as florestas naturais porque não servem de abrigo aos vetores das doenças. A floresta, portanto, do ponto de vista da modernidade, deixa de ser 
um valor em si mesma, para somente ser valorizada enquanto tiver alguma utilidade, seja ela econômica ou no âmbito da saúde. Na verdade, Navarro usa a higiene como um argumento de peso utilizado para convencer leigos a aceitarem o eucalipto.

\subsection{Utilitarismo}

O utilitarismo inglês influencia fortemente os intelectuais da Belle Époque ligados à agricultura. A lógica interna do utilitarismo, segundo Sevcenko (2003), centrase toda ela sobre o conceito de eficiência. Propõe a otimização de todas as suas energias visando uma elevação máxima do desempenho produtivo, num quadro de mínimo desperdício de esforço, recursos e de tempo.

Citando Eduardo Prado, porém sem fornecer a referência bibliográfica, Navarro fala que:

"as florestas industrial e comercialmente mais utilizáveis são as
compostas de uma só ou de poucas essências. A multiplicidade de
nossas essências florestaes misturadas num pequeno espaço, essa
própria riqueza aparente constitui industrialmente uma
verdadeira pobreza. É impossível deante de nossas exuberantes
florestas num tempo dado achar, cortar, puxar, lavrar e exportar,
em condições economicamente possíveis, uma quantidade de
madeira da mesma natureza, qualidade e tamanho, como exigem
os construtores e engenheiros, quando se dirigem a um
comerciante de madeira" (Apud. Andrade, 1912a, p.99).

Esta citação ilustra bem a noção de utilidade, entendida principalmente como sendo utilidade econômica, pois quanto mais lucrativa a floresta, mais útil ela é. Uma floresta boa para negócios é aquela que apresenta uma densidade apreciável de madeiras úteis (muitas árvores num dado espaço), homogêneas (muitas árvores aproveitáveis de grande valor de uma ou poucas espécies num dado espaço) e em terreno que facilite o seu corte e transporte. Porém, florestas com estas características não são encontradas nos trópicos. É a floresta otimizada. 
A utilidade das florestas é a noção central de sua obra. Navarro não quer apenas a floresta útil, ele quer a mais útil. Podemos, inclusive levantar a hipótese de que suas plantações de eucaliptos nos moldes em que as realizou, estaríam efetivando a transposição das características típicas das florestas de clima temperado, consideradas ótimas, para a região tropical. Isto porque, as características das plantações de eucaliptos por ele realizadas (densidade, homogeneidade de número de espécies e de ritmo de crescimento) são típicas da formação florestal de clima temperado e não de clima tropical. Conforme relatamos anteriormente, na Belle Époque havia um grande fascínio pelos modelos oriundos da Europa e da América do Norte, regiões de clima temperado. Ou seja, podemos supor que Navarro considerasse o modelo de floresta de clima temperado como superior não apenas em relação aos aspectos econômicos, mas também fundado na crença de que algo por ser europeu venha a ser automaticamente superior.

Podemos perceber que não existe em sua obra a concepção romântica de natureza entendida como "uma totalidade completa em si mesma e auto referida [como] um espetáculo natural [que se] oferece a degustação passiva dos sentidos” (Sevcenko, 2003, p.290). A natureza era concebida como paisagem a disposição do homem para seu deleite. A concepção romântica de natureza corresponde aos anseios da aristocracia e do Império.

Por outro lado, nota-se com clareza a concepção naturalista de natureza, na qual "a riqueza potencial da paisagem excita o desejo de apropriação e consumo predatório dos recursos inertes” (Sevcenko, 2003, p.290), isto é, a natureza deixa de ser objeto de contemplação e passa a ser submetida às leis do mercado, ou seja, passa a ser avaliada em função de sua utilidade econômica. A postura naturalista expressa os anseios da nova elite que passa a deter o comando político após a proclamação da República, na qual Navarro, a família Prado e os fazendeiros de café se inserem.

Num artigo não assinado n’O Fazendeiro, a concepção de natureza enquanto recurso econômico é expressa com nitidez:

"a matta virgem é espontaneamente bella, só ousará contestal-o quem nunca tenha atravessado suas picadas a hora quente do dia em que o sol 
ardente, cá fora parece lançar fogo na superfície abrasada da terra. Abriga no seu seio um sem número de maravilhas da natureza representadas pelos seres vivos que nella fizeram seu habitat. Mas essas razoes, todas poéticas, todas sentimentalistas, não podem pesar no problema agrário de uma região immensa em plena phase evolutiva (...).O valor da mata virgem em si é insignificante e, em certas condições, quase nullo" (O Fazendeiro, 1913, p.256).

A seguir, no mesmo artigo, apresentado o argumento em favor da silvicultura racional, como alternativa à concepção romântica:

"As derrubadas devem fazer-se com duas intenções: ou para sujeitar-se terrenos a culturas mais rendosas ou para nelles criar matas de boas essências, mas mattas reguladas, exploradas conforme as boas regras da sylvicultura, em que seu valor seja calculável, a situação bem escolhida e os seus produtos utilizáveis no commércio conforme com a menor despesa de preparo possível” (O Fazendeiro, 1913, p.257).

Embora de maneira não tão explicita, a concepção naturalista pode ser sentida num outro artigo de autoria desconhecida, pois não estava assinado, na revista $\mathbf{O}$ Fazendeiro, em seu número de estréia em 1908, no qual é dada orientação aos fazendeiros interessados em comprar um bom sítio. Informa que o melhor sítio é aquele que possui mata virgem:

"(...) A vestimenta das terras boas é representada em São Paulo, Minas e Rio de Janeiro, quase pelas mesmas plantas, principalmente pelas - Pau d'Alho, Figueira Branca, chamada Gamelleira nos Estados do Norte; Jangada Brava, Jaborandi Pintado, Sapuvo-Assu, Cabriuva, chamada Páu de Óleo nos Estados do Norte; Peroba, Cedro, Arandiuva e Jequitibá. Só o Jaborandi Pintado é pequenino. Todas as outras árvores são árvores grandes, muito grandes” (Martins, 1908, p.18-19). ${ }^{10}$

\footnotetext{
${ }^{10}$ Navarro também aponta a presença da figueira branca como sendo um indicador seguro de fertilidade do solo, sendo portanto recomendado a derrubada da mata para se plantar café (Andrade,1916, p.143).
} 
Como se pode observar há ainda um certo fascínio na descrição da exuberância da natureza, mas o aspecto utilitário prevalece: a existência dessas árvores de qualidade são um indicador seguro da fertilidade da terra para a plantação de café. O fazendeiro, portanto, pode comprá-la sem risco para poder derrubá-la e fazer sua plantação de café que terá retorno financeiro garantido. Compete ainda notar que o autor fala sem meias palavras sobre a conveniência de derrubar a mata nativa para se criar matas de boas essências segundo as regras da silvicultura.

Navarro lamenta a baixa qualidade econômica de nossas matas, embora do ponto de vista da diversidade, que interessa mais aos botânicos, e de suas belezas cênicas que interessaria mais aos poetas e prosadores, isto é, aos românticos que se deleitam com a paisagem, ele as considera ricas. Claramente inspirado em Eduardo Prado ${ }^{11}$ nos mostra que:

"infelizmente, o traço mais característico de nossas matas é a sua assombrosa riqueza em espécies vegetais, a quase incrível variedade de essências lenhosas.(...) mas essa riqueza que faz o assombro dos botânicos mundiais e o orgulho de nossos poetas e prosadores, constitui sob o ponto de vista econômico, um grande embaraço, uma verdadeira pobreza (...) A enorme heterogeneidade de nossas matas torna-as pouco utilizáveis industrial e comercialmente." (Andrade, 1923, p.5-6).

Argumenta ainda que derrubar a mata como finalidade econômica, ou seja, é dando uma utilidade a ela, não é destruição, mas sim uma prática legítima do proprietário:

"O simples fato de se terem derrubado muitas das nossas matas não significa que tenha havido devastação. O que houve e há é a utilização de nossas florestas, ou dos terrenos que elas ocupam, pois ninguém derruba pelo simples prazer de derrubar ou destruir, o que constituiria nos tempos que correm um gênero de prazer muitíssimo perigoso.” (Andrade, 1923, p.8).

Como se pode perceber, há nestas falas uma mescla de liberalismo que resguarda o direito do proprietário de fazer o que bem entender com sua mata, bem como a 
presença do utilitarismo dando à floresta uma finalidade econômica, que é a de transformá-la em dinheiro. Porém, como derrubar a floresta não é comercialmente viável, propõe uma alternativa mais lucrativa, que é a implantação da silvicultura racional ou moderna, nos moldes da praticada nos hortos da Cia Paulista de Estradas de Ferro, que produzirá uma mata mais útil:

"O que precisamos mesmo é cuidar do reflorestamento do nosso país, aproveitando para isso as terras mais pobres, impróprias para outras culturas, ao mesmo tempo é mister que cuidem os governos da manutenção e conservação das matas que protegem nossos mananciais, os cursos de águas e revestem os terrenos mais acidentados." (Andrade, 1923, p.13).

A noção de utilidade aparece de forma mais clara na citação acima. Primeiro quando diz que as terras mais férteis deveriam ser ocupadas por outras culturas que não o eucalipto certamente estava se referindo às culturas mais lucrativas de exportação, uma vez que a remuneração que o eucalipto oferece não é competitiva em relação àquelas culturas. A noção da necessidade de preservação não está ligada ao valor intrínseco da floresta, mas à utilidade que ela oferece para o meio ambiente: proteger mananciais, cursos de água e terrenos mais acidentados. Como a preservação de matas naturais não é uma atividade lucrativa, e por não ter nenhuma utilidade imediata para o fazendeiro individualmente, pois a preservação de um manancial afeta a um grupo deles, Navarro propõe que os custos desta iniciativa sejam arcados coletivamente, isto é, que se torne responsabilidade do Estado. Por fim, cabe ressaltar o uso da palavra "reflorestamento”. Para Navarro, praticar a silvicultura moderna é reflorestar e reflorestar com vantagem econômica $^{12}$. Logo em seguida, no mesmo livro ele explicita como deveria ocorrer o reflorestamento:

"precisamos formar matas uniformes, homogenias, de uma só, ou de reduzido números de espécies, cuja exploração possa ser mais

\footnotetext{
${ }^{11}$ Cf. opus cit. Andrade, 1912a, p.99.

12 O Fazendeiro apresenta o livro de Navarro, Manual do Plantador de Eucaliptus, como sendo um "trabalho de grande valor para aqueles que se interessam pela reconstituição de nossas matas" (O Fazendeiro, 1911, p.456).
} 
tarde, feita segundo as regras da silvicultura e cujos lucros correspondam ao que se podem e devem obter de uma cultura florestal, sem o processo bárbaro e inevitável de derrubar muitas árvores para poder aproveitar alguns metros cúbicos de uma determinada essência e sem necessidade de vender por preço irrisório, como lenha para locomotivas, madeiras de inestimável valor.” (Andrade,1923, p.13-14).

Reflorestar para ele implica em estabelecer plantações de uma ou poucas espécies de forma a se obter lucro. Por outro lado, Navarro reconhece também o valor da madeira nativa ao dizer que a queima das mesmas para abastecer as locomotivas não se constitui em um uso ideal.

Em 1916 é lançado em São Paulo e distribuído, por toda a Europa o livro de Navarro, Les Bois indigènes de São Paulo: contribuition a l'étud de la flore forestière de L'etat de S. Paulo, que se constitui em um catálogo das essências florestais nativas do Estado de São Paulo. Este, contudo, não é mais um estudo desinteressado à maneira dos naturalistas de outrora realizado em nome do conhecimento e da verdade científica, mas é um catálogo das espécies úteis do Estado de São Paulo, o que significa que se prioriza as espécies de maior valor comercial. Mas por que em francês? Por que a distribuição na Europa? A respostas a essas questões nos foram dadas pela resenha do livro, publicada n'O Fazendeiro, em $1916^{13}$. Desde 1914 a guerra devastava a Europa e isso certamente exigiria muita madeira para se reconstruir tudo o que fora devastado e os fazendeiros e comerciantes de madeiras paulistas não poderiam perder essa oportunidade de fazer excelentes negócios no exterior. Muda-se a concepção de natureza, bem como se altera a finalidades dos trabalhos intelectuais relativos a ela para se atender às novas demandas. Estudam-se as florestas para poder derrubá-las e torná-las úteis para a sociedade porque a madeira dela retirada permitirá a construção de muitas obras e, conseqüentemente, remunerará seus proprietários. Talvez

\footnotetext{
13 O Fazendeiro. Les bois indigènes de São Paulo: contribuition a l'étud de la flore forestière de L'etat de S. Paulo. São Paulo, p.270-273. Dezembro de 1916.
} 
seja esta a finalidade que Navarro quer dar às madeiras de inestimável valor, a exportação.

Em 1903, Navarro publica uma série de artigos sobre podas em árvores frutíferas e neles já estavam presentes as noções de utilitarismo. Começa falando dos objetivos de um pomar:

"entendemos que um pomar deve ser uma fonte de rendimento $e$ não um retiro poético e ameno. Isso só se coaduna com principescas fortunas [e que] a escolha da forma a dar a uma planta, não deve obedecer apenas à fantasia, a um capricho, ou às regras do bom gosto; deve atender principalmente ao rendimento dessa planta” (Andrade, 1903a, p.287).

E outro artigo, tratando do mesmo assunto, porém se referindo apenas às podas presas, que são aquelas em que a planta tem seu crescimento direcionado, amarrando-se seus galhos em estacas, Navarro comenta:

"Grande tem sido o abuso e pouquíssimo na verdade o senso que tem presidido a formação de árvores que de boas produtoras que eram, passaram a ser simples plantas ornamentais de vistosos parques, servindo apenas para deleitar a vista de seus proprietários. Mil formas têm sido adotadas, obedecendo única e simplesmente à imaginação mais ou menos caprichosa de algum hábil jardineiro" (Andrade, 1903b, p.449)

O pomar precisa ser avaliado em função de sua finalidade comercial e cada planta em função de seu rendimento. O autor é contra “podas presas” porque servem apenas para embelezar as vistas. Estas duas citações, entretanto, mostram a perspicácia de Navarro e o quanto ele era afinado com as idéias de seu tempo. Diz que um pomar para deleite do proprietário não é mais cabível, que isso só coaduna com fortunas principescas. A concepção que ele tem de pomar é equivalente à concepção de floresta gestada no período da Belle Époque e ambas são marcadas pela noção de utilidade. $\mathrm{O}$ deleite, tanto para floresta quanto para o pomar, pertence aos aristocratas, às fortunas principescas, não aos empreendedores. 
Navarro (1928) publicou um pequeno estudo de entomologia, no qual, de maneira bem distinta de seus contemporâneos, traz uma relação de insetos que atacam nossa “flora lenhosa” e quais são as árvores por eles acometidas. Este libreto tem por finalidade auxiliar os fazendeiros a identificar e combater as pragas que atacam suas matas reconstituídas, ou seja, foi construído sob o signo da utilidade econômica. O museu florestal por ele organizado no Horto Florestal de Rio Claro segue a mesma orientação como se pode observar na citação abaixo:

“Conseguimos também organizar no Museu do Horto Florestal da Companhia Paulista, em Rio Claro, importante coleção de insetos inimigos de nossa flora lenhosa, com material completo de 98 espécies e que é hoje, sem dúvida, a melhor do Brasil, pois que é superior a do próprio Instituto Biológico, de São Paulo.” (Andrade, 1930, p.251).

O utilitarismo aparece também nas experiências que Navarro realizou com formicidas. Não bastava escolher o melhor veneno, era preciso escolher também o mais vantajoso: "Existem, de fato, vários inseticidas no comércio, de comprovada eficácia, mas o problema não se resume apenas em extinguir formigas, é preciso extingui-las economicamente." (Andrade, 1915, p.147). Não basta ser o melhor inseticida tem de ser também o mais barato incluindo uma série de fatores: custo da aplicação, o que implica no custo e facilidade do transporte do inseticida e da água no qual será diluído; custo da mão de obra levando-se em consideração o tempo da aplicação; facilidade de aplicação e poucos riscos ${ }^{14}$.

Navarro chega até mesmo a fazer propaganda de uma carroça norte-americana como sendo de grande utilidade para transportes na fazenda. Trata-se da carroça Davenport - Roller Bearing, comercializada exclusivamente em São Paulo ${ }^{15}$.

Navarro adota também o registro pormenorizados de todas as suas atividades. Usa métodos estatísticos e está sempre a publicar os resultados, a estabelecer

14 "Há inseticidas que demandam tantos cuidados e cautela que somente o próprio fazendeiro ou o administrador poderá aplicá-lo, outros requerem tal dose de inteligência e cultura que, para seu emprego, teremos de excluir todo e qualquer camarada". (Andrade, 1915, p.147). 
comparações, a mostrar eficiência e produtividade. Como exemplo, podemos citar as estatísticas publicadas por Navarro no Boletim Agrícola no qual compara a produção de eucaliptos de diversas espécies no Serviço Florestal do Estado de São Paulo que fora de 189.772 exemplares, e que somadas às essências de outras espécies deram um total de 291.750 exemplares, ou seja “ 41.609 [a mais] que durante todo o ano de 1911 ou ainda mais 135.094 que o antigo Horto Botânico e Florestal de 1902 a 1910” (Andrade, 1912, p.512).

Em um artigo não assinado n'O Fazendeiro, que embora não podendo afirmar que seja de Navarro, tem muitas características típicas de sua obra, o autor comenta um artigo do Ralway Age Gazette, de Nova Iorque, que trazia dados a respeito dos rendimentos das plantações florestais da Estrada Ferro Ilinois Central, que cultivava eucaliptos desde 1898, e conclui que a Cia Paulista de Estradas de Ferro produzia eucaliptos com custos menores ${ }^{16}$.

Diante do acima exposto, percebe-se que os dados estatísticos além de orientar a produção, servia também para transmitir uma imagem positiva da Companhia, numa estratégia de marketing avançada para a época.

O primeiro artigo em que seus dados são contestados é de 1934, onde Koscinski realizou experiências semelhantes e chegou a conclusões não tão otimistas quanto as de Navarro, mas mesmo assim houve concordância:

"Aliás os resultados dos eucaliptos, aqui apresentados não são tão vantajosos como nos campos experimentais da Cia Paulista (Rio Claro) como nos informa Navarro de Andrade em $\mathrm{O}$ Eucaliptus e suas aplicações mas assim mesmo demonstram grandes vantagens sobre a bracatinga.” (Koscinski, 1934, p.18)

Não resta dúvida que Koscinski repetira as experiências com a intenção de contestá-lo.

\footnotetext{
${ }^{15}$ Andrade, 1914, p. 157.

${ }^{16}$ O Fazendeiro, 1915, p.191-192.
} 
Concluímos dizendo que as principais características do período da Belle Époque são as transformações dos espaços urbano e rural geradas em nível internacional pela presença do capital estrangeiro e pela forte influência que estes países, notadamente a França, exerciam sobre a elite brasileira de então. Entretanto, não se trata de simples imitação dos países estrangeiros, mas de um movimento que ocorre simultaneamente nos países centrais e periféricos do sistema capitalista. Do ponto de vista intelectual, o darwinismo, o sanitarismo, o utilitarismo exerciam grande influência sobre a intelectualidade e o positivismo e o liberalismo tiveram também forte interferência na construção do estado nacional.

\subsection{Outras considerações}

Até agora temos feito alusão exclusivamente a Navarro quando nos referimos a eucaliptos, mas cabe ressaltar que nas mesmas fontes consultadas havia outros escritores, pensando a silvicultura nos mesmos paradigmas modernos. Por exemplo, Revista Agrícola, em novembro de 1903, Germano Vert mostrou as vantagens de se reflorestar com eucalipto. No Boletim da Agricultura, em agosto de 1904, foi publicado um artigo bastante completo de Alberto Löefgren, traçando um histórico do eucalipto, falando das experiências no exterior e fornecendo instruções técnicas aos interessados em tal cultura. Na Revista Agrícola, em março/abril de 1907, Lourenço Granato publicou um artigo intitulado "Breves Instruções para a Cultura do Eucaliptus”, no qual fornece instruções importantes para os interessados nessa cultura. São todos artigos anteriores a Navarro, visto que a primeira publicação do seu A Cultura do Eucalyptus é de 1909. Então, podemos levantar a hipótese de que a silvicultura racional é uma proposta da elite agrária do período como um todo, que se organizava em torno da Sociedade Paulista de Agricultura, da qual Navarro foi o maior mentor e executor em função da disponibilidade de recursos que a Cia Paulista de Estradas de Ferro lhe proporcionava e da influência política que a Família Prado exercia. Ou seja, a silvicultura racional é um projeto de uma classe social e não de uma empresa ou de um indivíduo isolado. 
Mais adiante, no item 4.1 faremos a caracterização da agricultura tradicional, também chamada de métodos rotineiros de plantio. Essa apresentação se faz necessária para a compreensão da oposição que lhe fará a Sociedade Paulista de Agricultura em favor da agricultura moderna ou científica. 


\section{METODOLOGIA}

Os procedimentos metodológicos que nortearam a produção desta dissertação fundamentam-se nos moldes da pesquisa histórica.

Realizamos nossos estudos pautados na análise documental de material coletado em acervos públicos. Nas bibliotecas da ESALQ (Piracicaba/SP), da Universidade Estadual de Campinas e do Instituto Agronômico de Campinas foram consultadas as fontes oficiais analisadas nesta pesquisa, a saber: livros, periódicos, manuais e folhetos do começo do século XX que versam sobre a agricultura e silvicultura paulista. Procuramos coletar dados a respeito de Edmundo Navarro de Andrade, mas logo percebemos que sua obra estava intimamente ligada a outros setores, tais como, ferrovias, café, agricultura moderna, agricultura tradicional e conservação da natureza por isso então passamos a coletar dados abrangendo também estes temas.

Também pesquisamos no Arquivo Municipal de Vassouras (Vassouras/RJ), na Biblioteca Nacional no Rio de Janeiro, no Museu Paulista, também conhecido por Museu do Ipiranga, na Capital, no Museu Republicano (Itu/SP) e no Horto Florestal "Edmundo Navarro de Andrade” (Rio Claro). As fontes primárias por nós coletadas foram fichadas segundo normas da historiografia tradicional.

Em busca da maior compreensão e aprofundamento das informações coletadas foram empregados referências de autores-chaves como Sevcenko e Murari. Conceitos como evolucionismo, racialismo, utilitarismo e outros permitiram que realizássemos uma reflexão mais aprofundada dos tópicos eleitos para a análise.

É importante ressaltar que o objetivo principal desta pesquisa foi elaborar um panorama do desenvolvimento da agricultura moderna, reunindo, trazendo a tona e 
analisando personagens, textos, artigos e manuais importantes para a compreensão de período tão significativo para o desenvolvimento da agricultura nacional. 


\section{RESULTADOS}

\subsection{A agricultura tradicional}

O Segundo Distrito Agrícola, subdivisão da Secretaria da Agricultura, Indústria e Comércio do Estado de São Paulo, com sede em Campinas, promoveu em 1900 um concurso regional com o objetivo de conceder um diploma de superioridade para " $a$ mais notável" fazenda da região. Este concurso tinha uma finalidade educativa explícita: era um incentivo ao progresso. Incentivo promovido pela:

"emulação que excitam entre lavradores e fazendeiros; pela certa e segura avaliação dos maquinismo e instrumentos, julgados no trabalho e sobre os resultados préticos; pelo sentimento de solidariedade que despertam entre os produtores, que melhor compreendem a sua comunidade de interesses; pela mesma animação que vem trazer àqueles menos proveito pareceriam dever deles tirar. Os Concursos Regionais são um dos maiores incentivos ao progresso” (Revista Agrícola, 1900, p.238).

Este concurso constará de quatro provas:

"Primeira prova: Exame experimental de instrumentos de lavoura, charruas, sachos, semeadores e outros, bem como de arreios e jugos para os mesmos.

Segunda prova: Exames práticos de descascadores de milho, de moinhos agrícolas, desintegradores, etc.

Terceira prova: Julgamento dos instrumentos e aparelhos, e dos gêneros e produtos apresentados.

Quarta prova: Julgamento dos animais apresentados.” (Revista Agrícola, 1900, p.265). 
Este concurso nos chamou sobremaneira a atenção, sobretudo porque falava em progresso, e por progresso entendia-se o uso de máquinas agrícolas que nós hoje passamos a considerar como sendo antigas, ineficientes, obsoletas, como representantes de atraso cultural no trato das coisas do campo. Logo, ficou evidente a necessidade de se definir o que era modernização da agricultura. Mas se aquilo que entendíamos ser a agricultura tradicional era quase que inédita na alvorada do século passado, qual era o tipo de agricultura que se praticava até então, no início do século XX? Quais eram as práticas agrícolas consideradas inadequadas por aqueles que se diziam adeptos da modernização? E, portanto, o que era modernização? O que fazer para se alcançar a modernização do espaço agrícola?

Neste capítulo faremos apenas uma descrição da agricultura tradicional, analisando alguns de seus aspectos, para dirimir dúvidas a seu respeito, pois tivemos muita dificuldade em conceituá-la porque considerávamos a agricultura moderna em suas características primitivas, anteriores à Revolução Verde como sendo tradicional, o que é historicamente incorreto.

A agricultura tradicional, praticada ainda em quase todo o país no início do século XX, fora iniciada no Brasil com a chegada dos primeiros colonos no século XVI e teve forte influência de elementos indígenas e africanos.

Carmo, no seu libreto Considerações históricas sobre a agricultura no Brasil (1939), nos demonstra que "instrumentos aratórios em uso na Velha Europa desde milênios tantos, seriam aqui sem nenhum préstimo”. Isto porque, os aborígines não estavam ainda preparados para lidar com eles. A mata virgem, muito agressiva, com suas árvores gigantescas, constituía-se num empecilho e precisava ser dominada:

\begin{abstract}
"Mas com que instrumentos derrubar por terra tais gigantes monstruosos? Mas forçoso era, não obstante, reduzir todo esse caa-eté (mataria) a capoeira (mato que já foi). Deu então o índio a primeira lição ao luso invasor: cumpria roçar, abater a machado, a terçado, à espada, e depois entregar tudo ao fogo, o grande o maior auxiliar do homem na fase áspera da luta deste contra a mata." (Carmo, 1939, p.2).
\end{abstract}

Com certeza, os primeiros produtos plantados pelos portugueses nos primeiros roçados foram a mandioca, e "próximo a um regato, um reduzido quartel de cará e 
taioba. Também plantaram alguma outra arácea” (Carmo, 1939, p.2). A implantação destes roçados fora, sem dúvida, um trabalho penoso, com o qual:

"o índio por desporto, por curiosidade, cooperava, porquanto este, na sua índole de homem nômade e sem senhor, entendia cooperar com o luso tão somente, indicando-lhe a utilidade de um sem número de vegetais e frutas da terra, sem ir além” (Carmo,1939, p.2).

Em outras palavras, os índios, por sua natureza nômade, e pelos seus hábitos de viverem sem senhores não se adaptaram ao trabalho agrícola sistemático tal qual queriam os portugueses.

Segundo Carmo (1939), uma vez plantado o mandiocal, "seguiu-se a caapina, isto é, o corte do mato que surgia e continuava a surgir cada vez de novo”. No ano seguinte não ousavam enfrentar de novo o caeté, e usando da lei do mínimo esforço, aproveitavam-se da área da primeira roça até que ela se exaurisse. A terra cansada era chamada de tigüera pelos paulistas.

Aos poucos foram chegando os vegetais já aclimatados nas ilhas portuguesas do Atlântico, tais como, a cana-de-açúcar, a bananeira, ambas procedentes da Ásia, e a vinha que se adaptou a São Vicente, uma das capitanias do sul. Porém, a maior dificuldade que se apresentava dizia respeito à mão de obra. Não se adaptando, não querendo ou não sendo em número suficiente, os portugueses não estavam dispostos a trabalhar diretamente na lavoura. Também o índio, por não se adaptar à vida sedentária, ao trabalho sistemático e se recusar a viver sob o jugo de um senhor, não se adaptava à faina agrícola. Carmo então se pergunta:

"quais os homens capazes de investir contra o caeté com certeza de vencê-lo e reduzi-lo à capoeira e mais tarde em gleba mansa própria aos instrumentos aratórios do reino? [A terra] era abundante e feraz, era por toda a parte onde quer que o reinol passasse, mas como fazer dela nascer utilidades, sem homens para roteá-las, sem homens para fazer o seu roteio?" (Carmo, 1939, p. 4)

A resposta a esta questão nos é sobejamente sabida, a solução, a “salvação”, como diz o autor, foi a importação de escravos africanos, prática que somente findara em nosso país, no século XIX, com as restrições inglesas ao tráfico e com a abolição da 
escravidão em 1888. Ao falar da importância do negro para ao Brasil, nosso autor abusa de qualificativos hoje considerados negativos. Entretanto, devemos ter o cuidado com o julgamento moral, pois em 1939 não havia ainda a noção de “politicamente correto”, e o racialismo ainda imperava forte. Portanto, a transcrição das palavras duras do autor aqui e em outros pontos não significa concordância com elas:

“Chegou-nos, pois o negro (...) que já havia atingido um grau de civilização bem superior ao do índio (...), prestou-nos um valiosíssimo serviço. O negro fez o Brasil com seu braço forte $e$ sua resistência ao clima, e mais deu-nos a afetividade amorável da sua índole de animal dócil e submisso. (...) Ficou sendo o motor pra tudo, o pau para toda obra, pois, desde breve tempo, nada se fará sem o concurso do negro ou da negra. Esta, sobretudo como animal propriamente caseiro os mais estranhos serviços prestava... Era o negro o animal utilizado no transporte de coisas e pessoas, motor nas operações de qualquer faina manual e a fêmea da espécie empregada até para os misteres da lactação”. (Carmo, 1939, p.4)

Estava lançada a base para a nossa agricultura colonial que vai perdurar também no período imperial e chegar à República, e em muitos rincões persiste ainda hoje. A agricultura brasileira começava:

"pela derrubada, depois a queimada, a coivara, o plantio e a capina pela enxada, colheitas feitas à mão e todas as demais operações sobre os produtos da terra sempre feitas pelo negro, motor quase único em todas as fainas agrícolas". (Carmo, 1939, p.4)

As derrubadas, as queimadas, as semeaduras sobre um monte de cinzas eram feitas geralmente morro acima, quase sempre poupando as várzeas férteis, porque o trabalho nas encostas era incomparavelmente mais fácil ${ }^{17}$. Temos então outra característica da lavoura colonial, o nomadismo:

"A agricultura então criada, visando plantio sobre montões de cinzas pelas encostas acima, era uma agricultura nômade,

\footnotetext{
${ }^{17}$ Monbeing entende que, no referente à lavoura cafeeira, a preferência pelas terras altas se dá em função do clima: "Os fazendeiros conhecem bem a inversão térmica (...) ocasiona neblinas frias e geadas brancas (.. ) As plantações dão-se mal com as neblinas de fundo de vale e é preferível conservar aí a floresta intacta.” (Monbeing, 1984, p. 67-68)
} 
porquanto, via de regra cultivada, a área cultivada dois ou três anos seguidos deixava-se em pousio - estava cansada, dava-selhe o merecido repouso. E lá o bom agricultor só tornaria quando a tigüera já houvesse transformado em capoeira grossa". (Carmo, 1939, p.6)

Carmo (1939) acrescenta que, naquelas eras, com o tipo de agricultura praticado, "nenhum outro instrumento rural teria cabimento fora do machado, da foice, da enxada tendo o homem como motor único e indispensável”.

O trabalho do agricultor tradicional assume características de trabalho infindo, de labuta incessante:

"Este pobre homem labutará penosamente no início de sua modesta lavoura, criada ali na várzea em terra bravia, exigindo roçada, queimada, coivaras, extração de tocos e raízes: enfim labuta incessante. (...) Nos anos seguintes nosso enxadeiro estará a abrir novas roçadas sempre com a mesma trabalheira". (Carmo, 1939, p.6)

Carmo mostra, com a descrição acima, não só o caráter cíclico do trabalho agrícola, como também da luta incessante contra a natureza, pois permanece sempre indômita, sempre a ser vencida. A vitória do homem sobre ela nunca é definitiva. Diante do exposto podemos concluir que o trabalho no campo não se mostrava nem fácil nem ameno, mas uma labuta ingrata sob o sol tropical” (Murari, 2002, p.148).

Conforme demonstra Carmo (1939), a agricultura afro-luso-brasileira preponderou em todo o país, exceto em áreas do Rio Grande do Sul e Santa Catarina e em regiões de São Paulo, principalmente na Vila Americana.

Podemos então concluir que a agricultura tradicional era aquela praticada com a derrubada da mata com foice e machado, queima, semeadura, capina com a enxada, colheita, todas as operações exercidas somente com a força dos braços e com uma característica nômade, uma vez que ocorrido o desgaste da terra escolhia-se outra área para derrubar a mata e reiniciar todo o processo.

Embora tardio, o texto de Carmo é de 1939, podemos observar forte influência darwinista. Ao analisar a agricultura tradicional notamos a influência de Darwin na percepção da luta do português colonizador contra o meio, mais especificamente contra 
a floresta, na labuta que nunca termina e está sempre recomeçando. Há um assustador conflito entre os desígnios humanos e as forças de resistência da natureza, que é vista como o domínio da barbárie, portanto como algo a ser dominado e civilizado. Devido à falta de disponibilidade de meios, isto é, de instrumentos e técnicas adequadas para enfrentar as forças de resistência das florestas, a luta se torna incessante, pois a floresta precisa estar sempre sendo derrubada, o solo em pouco tempo se desgasta, a floresta se recompõe depois de alguns anos de abandono e o homem derruba novamente outro pedaço de mata, enquanto aguarda que aquele desgastado se recomponha, num ciclo quase infinito, num eterno recomeço.

Pode-se dizer, de acordo com Murari (2002), que o sentimento predominante a respeito da relação do homem com a natureza é da inexorabilidade, do fatalismo derivado da imposição das leis naturais sobre a humanidade. A inexorabilidade e o fatalismo se traduzem por um sentimento de impotência para se obter soluções definitivas.

Segundo Murari (2002), a natureza era vista como um conjunto de condições hostis, ameaçadoras, frente às quais o homem pouco dispunha para sua defesa, por outro lado o homem também passava a ser visto como um agente destruidor. A batalha sem fim do homem contra a natureza hostil forja uma imagem do mundo natural como um conjunto de forças contrárias, violentas, opressoras, dotadas de um imenso poder de aniquilação.

O trabalho no campo era maçante, o português por si só era impotente diante do meio natural, precisava do intercurso de outros homens, acreditava-se então, de raças consideradas inferiores, pouco acima da animalidade. Eis outro aspecto do darwinismo social, entendido como a aplicação de valores subtraídos das ciências naturais para entendimento das relações humanas: o racialismo. Concomitantemente, temos a crença no imigrante estrangeiro como fator de progresso por serem considerados seres de raças superiores. Aliás, de acordo com Murari (2002), os conceitos de caipira e caboclo, sempre considerados inferiores, também têm conotação racial: ambos são mestiços de portugueses com índios. 
Seguindo os mesmos princípios da agricultura tradicional, a grande lavoura de exportação também se baseava na devastação e na queima de florestas virgens, no plantio desordenado e na capina sem nenhuma forma de correção e fertilização do solo. Este tipo de agricultura induzia ao nomadismo, pois o campo aberto pela queimada, a princípio muito fértil, desgastava-se rapidamente por outras queimadas e pela falta de cuidados, tinha uma curta vida útil, cerca de seis anos após a qual era completamente abandonado. A queimada, geralmente empreendida entre os meses de julho e outubro, época da seca, beneficiava somente uma colheita com os sais da requeima dada a volatibilidade destes adubos.

O balanço do emprego das queimadas, segundo Murari (2002) baseada em Warren Deam, é bastante negativo, tendo como conseqüências a impermeabilização do solo, a destruição das fontes de umidade, o consumo de azoto, a interrupção da difusão natural das sementes das árvores, a morte, principalmente dos filhotes, ou fuga dos animais da floresta.

A modernização implantada no país a partir de 1870, com a restrição da escravidão (Lei do Ventre Livre), construção das ferrovias e início da imigração não conseguem pôr fim à agricultura tradicional. Teremos de esperar o fim da escravidão, o Regime Republicano e a grande crise da economia cafeeira para que lentamente novas formas de organização do espaço rural e de plantio sejam adotadas.

Entretanto, podemos dizer que mesmo com a implantação da agricultura científica, o processo de desmatamento não se alterou consideravelmente no início do século XX: tradicionalmente contingentes significativos de trabalhadores livres nacionais, os caipiras e caboclos que sobreviviam como posseiros ou agregados, eram mobilizados para a derrubada, a queimada e a limpeza da terra. De acordo com Murari (2002), os fazendeiros que não dispunham de capital elevado apelavam com freqüência para empreiteiros que realizavam os trabalhos de derrubada, queima e limpeza.

No final do século XIX já eram perceptíveis os males causados por este tipo de agricultura tradicional nos estados de São Paulo e, principalmente, no Rio de Janeiro. 
Paes Leme (1900) comenta a polêmica gerada por um jornalista no Rio de Janeiro sobre os malefícios que a cultura cafeeira estava causando à natureza e notadamente ao clima e ao solo. O jornalista fluminense, citado por Paes Leme, atribui:

"à derrubada das matas nos cabeços dos morros e em suas encostas, as secas periódicas e as chuvas torrenciais, que lavam os montes e levam aos rios, com rapidez vertiginosa, a melhor parte de nossa fertilidade.(...) [mostra] que só nas grotas e nos terrenos sombrios se encontrava a vegetação luxuriante que caracterizava as culturas de café, outrora tão bem cuidadas e que se estendiam por léguas e léguas.” (Leme, 1900, p.81).

A cultura cafeeira, portanto, promovia o desgaste do solo, e a vegetação somente se encontrava preservada em algumas regiões, os grotões e lugares sombrios, ou seja, lugares de difícil acesso, quase que imprestáveis para a agricultura. Onde outrora havia mata luxuriante, depois lavoura de café, "hoje encontra-se apenas o campo raspado e estéril” (Leme, 1900, p. 81). Havia, pois, a necessidade de se procurar novas áreas para o plantio, deixando atrás de si um rastro de destruição:

"E, à lavoura de café, essa cultura vampiro, cabe a responsabilidade inteira de todos os males: nada se respeitou e a ferro e fogo, destruiram-se municípios e províncias, sem cogitarse o dia de amanhã, contando-se tão somente com as frondosas matas dos Estados vizinhos.

Este regime não aumentou a fortuna pública, apenas desloca a riqueza, deixando atrás de si a ruína e a tristeza." (Leme,1900, p.83).

Notável percepção a do autor. A marcha do café, que na escola primária teimam em se comparar à marcha dos bandeirantes no desbravamento dos sertões, nada mais foi do que o deslocamento da cultura devido à incúria humana, deixando atrás de si o abandono e a miséria. O autor conclui que a crise da lavoura fluminense era atribuída “com certeza à derribada das matas, à ferro e fogo sem regularidade, [que] é a causa única de todos os males” (Leme, 1900, p.83). Entretanto, segundo Murari (2002), não são apenas as derrubadas que levam à procura de novas terras virgens para plantio, mas também o desgaste vertiginoso da fertilidade da terra, que deixava para trás seu rastro de decadência e assolamento. 
Portanto, percebemos que em 1900 já se tinha uma percepção crítica dos males que este tipo de agricultura causava: a devastação dos solos.

No relato supra citado de Leme, assistimos a derrota do homem para a natureza. O homem será obrigado a se deslocar para outras terras em função do rápido desgaste do solo, o que de acordo com a noção de luta pela sobrevivência pode ser interpretado como fuga causada pela derrota a eles infligidas em virtude dos poucos conhecimentos e técnicas disponíveis para seu enfrentamento. Muitos fazendeiros cujas terras se tornaram improdutivas devido ao desgaste do solo no Vale do Paraíba Fluminense ocuparão novas terras no chamado oeste paulista, tais como. Pereira Barreto que se estabelecerá na região de Ribeirão Preto e de Santos Werneck, no Banharão.

Outro aspecto a ser destacado é o caráter destruidor desta ocupação: a expansão da colonização européia significou desde a descoberta do Brasil, a deflagração de uma guerra aberta contra a natureza.

Ainda segundo Murari (2002), o conflito do homem contra a natureza ganha um duplo sentido: tanto a natureza mostrar-se-ia um conjunto de forças hostis e predispostas a eliminar o esforço humano, quanto o homem tornava-se um destruidor implacável e irresponsável.

A exploração européia desde o descobrimento até o final do século XIX, de acordo com Murari (2002) apoiada e Warren Deam, deu-se a partir do contato de técnicas já em uso pelos nativos, que já devastavam a Mata Atlântica antes da chegada de Cabral. As grandes propriedades de terras atribuídas aos colonos mantiveram o regime indígena de exploração extensiva do solo baseado nos métodos de abertura de terrenos para a agricultura, a derrubada e a queimada, o que explica a vertiginosa devastação das florestas.

A agricultura e a pecuária assumiram um caráter itinerante que, associado ao uso do fogo, aumentou a pressão sobre a floresta. O fogo era a arma de enfrentamento mais eficiente que o homem possuía então, pois provocava resultados rápidos e definitivos, embora de difícil controle, já que muitas vezes queimavam-se áreas maiores que as desejadas porque era difícil evitar que o fogo se espalhasse para áreas vizinhas. 
Navarro, através de seus artigos, seus trabalhos científicos, seus manuais será um dos mais aguerridos combatentes da agricultura predatória e o fará em uma empresa particular, a Companhia Paulista de Estrada de Ferro, interessada na plantação de eucaliptos para alimentar suas locomotivas.

Ressaltamos ainda que, segundo Murari (2002), a elite brasileira foi formada de acordo com os dois paradigmas: o naturalista e o moderno, ou seja, fazia-se a leitura do meio físico e socioeconômico de acordo com os paradigmas naturalistas, devido à precariedade do emprego de técnicas no campo, que impossibilitava o pleno domínio da natureza e usava-se o paradigma modernista como perspectiva de transformação tanto da natureza como do meio socioeconômico. Este será o assunto do nosso próximo capítulo, que vai analisar como ocorre a incorporação e a colocação em prática dos princípios da agricultura moderna.

\subsection{A agricultura moderna}

\subsubsection{A gênese da modernização da agricultura em São Paulo.}

Em 1901, Pereira Barreto fizera uma viagem aos Estados Unidos da América. Durante esta viagem escrevera ele em artigo publicado no jornal norte-americano The Daily Picayune, de Nova Orleans, depois traduzido na Revista Agrícola, que os Estados Unidos “deveriam ser o modelo principal nesse progresso material e industrial no qual o Brasil tanto precisa.” (Barreto, 1901, p.171). A principal ênfase do artigo é na exportação de maquinaria agrícola que aquele país potencialmente poderia realizar para o Brasil.

Em fevereiro de 1902, já se faz sentir forte a crise de superprodução de café resultante do plantio excessivo que se fizera em anos anteriores, na época do Governo Campos Sales, em virtude da facilidade da concessão de créditos decorrente de sua política econômica que ficou conhecida por Encilhamento.

Na Revista Agrícola, a crise é tratada com um tom apocalíptico:

"Nos momentos críticos, quando o espectro da miséria se alevanta diante de nós, nítido, frio, descarnado, deixando ver bem desenhada em sua atitude imisericordiosa da situação social, é 
permitido, é justo, é indispensável que o nosso espírito se entregue à toda sorte de conjecturas, e procure um remédio para nossas aflições.” (Barreto, 1902b, p.75).

Barreto pergunta-se se a lavoura de café não tem mais futuro, se não estará tudo perdido. Se não haverá outra cultura capaz de preencher o vácuo deixado diante do iminente desaparecimento da lavoura do café.

A cultura do café, que outrora fizera fortuna de muitos agricultores, já não era mais remuneradora ao produtor devido à baixa cotação do produto no mercado e ao alto custo de mão de obra. Já estavam produzindo com prejuízo. O autor comenta que a grande vantagem dos países concorrentes são os baixos custos da mão de obra, mas aqui faltam braços, com o que então a redução de salários não seria conveniente. Propõe que seria preferível buscar nos instrumentos agrícolas mais aperfeiçoados a solução para este problema.

\section{Barreto é enfático:}

“ a questão da produção, de modo mais econômico é tarefa que está a reclamar de todos nós as mais detidas reflexões. Produzir mais barato equivale a vender mais caro [...] A Revista Agrícola acolherá com desvanecimento toda e qualquer contribuição neste sentido e proclama que é uma questão vital na ordem do dia: o meio de produzir mais barato.” (Barreto, 1902b, p.75).

Esta questão ainda estará em pauta por muito tempo ${ }^{18}$. Pestana (1908) argumentando que a superprodução de café é fruto da nossa civilização recomenda baixar os custos, "obedecendo as correntes do mundo moderno, que aconselham a produzir muito para vender barato”. (Pestana, 1908, p.86).

Parece haver um consenso na Sociedade Paulista de Agricultura a respeito da necessidade se modernizar a produção como meio de baratear custos e aumentar a competitividade do café no exterior. Este barateamento seria alcançado com o uso de maquinário agrícola, que torna o trabalho humano mais produtivo e com um novo tipo de colonização, na qual, a exemplo dos Estados Unidos, se fixaria o homem no campo

\footnotetext{
${ }^{18}$ Em O Fazendeiro, em 1917, há uma nota informando existir no serviço florestal dos Estados Unidos uma máquina de plantar que permite a um homem plantar de 10.000 a 15.000 mudas por dia, enquanto que um operário muito esperto planta no máximo 1300.
} 
transformando-o em cidadão proprietário, o que provocaria um adensamento da população do país aumentando a oferta de mão de obra. Estas propostas vão ganhando corpo na Revista Agrícola. Viagens ao exterior são relatadas, as máquinas agrícolas são quase que louvadas. Novas técnicas de plantio são apresentadas. Começa, então, um forte entusiasmo pela modernização, pela então chamada agricultura científica.

Em 1902, o Senhor Carlos Botelho, médico, proprietário de grandes fazendas de café em São Paulo, também ligado ao setor ferroviário, empreendeu uma grande viagem aos Estados Unidos da América do Norte com a finalidade de conhecer a agricultura daquele país. Ficou muito impressionado como o que viu. Admirou-se ao visitar as estações experimentais, as escolas agrícolas, as ferrovias, principalmente os carros frigoríficos, que permitiram as frutas da Califórnia serem exportadas pelos portos da Costa Leste. Surpreende-se também com a iniciativa do povo norte-americano:

"esse progresso agrícola, industrial, intelectual dos Estados Unidos da América (...) não [é] mais do que a conseqüência benéfica da liberalidade de uma constituição que permite a cada cidadão o máximo emprego da própria iniciativa individual a princípio, agremiada em seguida, exercitada e nacionalizada por fim" (Botelho, 1901, p.266)

Podemos observar que o autor atribui a grande capacidade de iniciativa e esforço individual dos americanos ao liberalismo presente em sua Constituição.

Entende o autor que os Estados Unidos da América do Norte se constituem no único exemplo digno de ser imitado: "Por que não importamos estrangeiros de ciências feita no único país digno de ser nosso luzeiro no terreno agrícola, a América do Norte?” (Botelho, 1902, p.14).

Em seguida, uma série de quatro artigos seus com o título de “A Colossal Riqueza da América do Norte” começam a aparecer na Revista Agrícola. Outros interessados em agricultura científica começam a viajar para os Estados Unidos. Artigos em favor da agricultura científica passam a ser publicados por diversos autores.

Mello (1902) publica um artigo no qual descreve seis instrumentos agrícolas de uso corrente nos Estados Unidos. O autor comenta as visitas que fez aos campos de experiências, (experimental farms) e as diferentes culturas agrícolas daquele país, bem 
como aos estabelecimentos de fabricação de máquinas agrícolas. Faz uma defesa intransigente da mecanização da agricultura nacional.

Em maio de 1902, após o quarto artigo de Carlos Botelho ser publicado, é a vez de José Pedro Cardoso, que também estivera visitando a América, enaltecer o progresso daquele país, cuja expressão máxima para ele eram as indústrias e as ferrovias. Fala até mesmo do amor pelas árvores ${ }^{19}$, mas a ênfase de seu artigo recai mesmo sobre um novo arado de disco.

Em 1903, logo após o congresso agrícola, em editorial, embora assinado pelo Doutor Luiz Pereira Barreto, a Revista Agrícola propõe, inspirada nos modelos de associação norte americanos, a união da classe agrícola para enfrentar a crise cafeeira que estava instalada no país:

\begin{abstract}
“(...) nos países civilizados, a formação de sindicatos, cooperativas têm produzido verdadeiras maravilhas na esfera da economia rural. É só pela convergência de vontades e opiniões que uma classe pode se impor ao respeito e fazer valer qualquer aceno seu no sentido dos seus legítimos interesses." (Barreto, 1903, p.47)
\end{abstract}

Faz, portanto, um apelo à união e à consciência coletiva no sentido da ação. Critica aqueles que apenas pressionam o Estado exigindo solução governamental na forma de créditos. Critica a classe agrícola por não compreender o papel do governo em relação à agricultura e por isso se deixa tomar pela obsessão de tudo esperar da iniciativa governamental. Em seguida, procura definir qual seria o papel que uma direção governamental patriótica apta e inteligente poderia trazer ao país.

Trata-se, portanto, de uma plataforma política de reivindicações dos fazendeiros associados e representados pela Sociedade Paulista de Agricultura, da qual a Revista Agrícola era porta-voz, tendo em vista as eleições para o governo do Estado de São Paulo, que estavam próximas. Propunha a união da classe agrícola em torno de um programa, o programa da SPA, que era o sindicato dos agricultores, no sentido norte-

\footnotetext{
${ }^{19}$ João Pedro Cardoso era inspetor do Segundo Distrito Agrícola e foi o introdutor do arbor day no Brasil em 1902, no município de Araras, que é comemorado até hoje nas escolas do Brasil inteiro com o nome de dia da árvore.
} 
americano da palavra, ou seja, no sentido de corporação, em favor da modernização da agricultura.

O primeiro ponto programático que o autor salienta é a necessidade do reconhecimento da agricultura ser o esteio da nação:
"A América do Norte é hoje a primeira potência do mundo porque nela está a primeira agricultura do mundo. O programa dos homens de estado norte-americanos é o programa de Cromwel: tudo pela Agricultura.” (Barreto, 1903, p.49).

Ou seja, acreditava-se na vocação agrícola do nosso país e que, tal qual ocorrera nos Estados Unidos, onde a agricultura era o esteio da nação, a salvação do Brasil estava na construção de uma nova agricultura, a agricultura racional seguindo o exemplo daquele país.

Em seguida, Barreto mostra as vantagens da agricultura racional para o desenvolvimento do próprio aparelho do Estado:
"O governo norte-americano compreendeu bem que as fabulosas somas, que gasta no Serviço da agricultura, voltam depressa para o Tesouro, depois de comunicar a todo organismo da nação, como uma corrente elétrica, a mais pujante força de expansão." (Barreto, 1903, p.49).

É uma tentativa de convencer os agricultores de que o crescimento da agricultura racional implicará também no crescimento do Estado, pois aumentará a arrecadação de impostos, sendo que, portanto, toda a nação será beneficiada por ela, a agricultura racional e não apenas os lavradores. Este é um importante fator de persuasão para agregar ao projeto modernizador da agricultura setores não a ela diretamente ligados, principalmente os partidos políticos, que a incorporará em seus programas, parlamentares, que viabilizarão politicamente o projeto e a imprensa, a grande mídia da época, que fará a divulgação e defesa da agricultura moderna junto à população, que espera-se, votarão nos políticos a elas relacionados.

O segundo ponto levantado é a necessidade de ensino agrícola sob todas as formas e em todos os graus: 
"Acolá, [nos Estados Unidos] as escolas agrícolas, as estações agronômicas, os campos de experiências colocam diante dos olhos do lavrador o quadro de todas as culturas, que o podem conduzir à fortuna." (Barreto, 1903, p.49).

Como se pode observar, a promessa aos agricultores que aderirem ao projeto é a de fortuna, o que torna o projeto político de modernização da agricultura atraente para os agricultores. Prometem aos agricultores brasileiros as possibilidades de se obter uma riqueza igual a de seus pares na América do Norte. Também a já mencionada série de quatro artigos de Carlos Botelho publicados na Revista Agrícola relatando sua visita àquele país, publicada com o título de "A colossal Riqueza dos Estados Unidos da América do Norte” contém a mensagem implícita de que poderemos atingir aquele nível de riqueza. Uma proposta bastante atraente, sem dúvida.

A política agrícola do governo americano é enfatizada:

"Nada do que diz respeito à política agrícola é insignificante para o governo Americano. Com sua magistral carta geológica, com seu bureaux de estudos de solo indica seguramente a cada um o que convém para tais e tais culturas. Nenhum passo em falso pode aí dar o trabalhador que tenha pela primeira vez uma cultura. As sementes das melhores e mais robustas variedades de trigo, raças do país, obtidas por hibridação de seus campos de experiências, a pomologia, a cultura de legumes e de flores. A criação de animais e os meios de combatê-los, a introdução de plantas novas, os trabalhos de irrigação por toda parte onde a aridez do solo reclama a água. O conhecimento exato dos alimentos tanto para o homem quanto para os animais, tudo, tudo corre por sua conta e sob suas vistas imediatas e um sem número de publicações levam até o último recanto da nação instruções precisas, para evitar embaraços e tropeções ao cultivador da terra." (Barreto, 1903, p.49).

Embora esta citação seja excessivamente longa, ela se faz necessária por que é uma síntese admirável da política agrícola norte-americana e deverá se constituir num conjunto de medidas que poderão ser adotadas no Estado de São Paulo com a finalidade de conduzir novamente ao sucesso a agricultura paulista. Em seguida argumenta que tais experiências não podem ser feitas por particulares porque seu custo é oneroso e os riscos grandes, e que os benefícios quer positivos quer negativos são de caráter público, então 
se deve fazer recair sobre todos os sacrifícios das despesas. Ou seja, acaba por definir e justificar quais seriam as tarefas do estado em relação à agricultura, bem como justificando tamanhos gastos.

Como prova cabal do sucesso do modelo agrícola norte americano o autor cita dois exemplos, um da adaptação da laranja bahia nas terras da Califórnia, que transformaram os Estados Unidos no maior produtor e exportador mundial de laranjas. E o fato de os Estados Unidos terem se tornado o maior exportador de maçãs para a Europa, onde este é considerado um fruto ordinário. A importância da maçã para a economia daquele país reside no fato de que ela se constitui numa lavoura dez vezes mais importante que cultivo de café entre nós, ou seja, presume-se que a maçã fosse dez vezes mais rentável que o café. A cultura da maçã só se tornou possível devido à criação de carros frigoríficos nas ferrovias que permite longas viagens sem que o produto seja estragado.

O terceiro aspecto a ser imitado no que se refere ao modelo americano é sua política de povoamento:
"Porque não devemos imitá-los ao menos neste caso do povoamento do país? Que fizeram eles para atrair a imigração $e$ convertê-la em colonização? (...) seu único segredo foi: transformar prontamente cada imigrante em possuidor de uma parcela do solo nacional.” (Barreto, 1903, p.51).

O que os cafeicultores estão reivindicando é baratear a produção para que mais pessoas tenham acesso à bebida que fazia a riqueza nacional. Entretanto, nos diz Barreto que a barateza do braço "não será possível enquanto não tivermos uma densa população” (Barreto,1903, p.51). Propõe um aumento de população como uma forma segura de se baratear o custo da mão-de-obra.

Em 1904 é publicada uma resenha do livro A Vida Americana. Industria Pastoril, Agricultura e Fábricas dos Estados Unidos da América do Norte, de P. de Rosiers. Neste livro está descrito

"o espelho que precisamos nos mirar, para sabermos o que nos cumpre fazer se queremos imitar todos os passos, que conduziram os americanos do norte as culmináveis do poder e das riquezas. Este livro nos indica o verdadeiro caminho que devemos trilhar. [Deveríamos imitar] os costumes, a energia no modo de empregar 
a atividade, o espírito de recursos, que aquela raça manifesta, que aquela raça manifestou na esfera da indústria pastoril, na agricultura e nas fábricas.” (Revista Agrícola, 1904, p.106).

Como se percebe esta plataforma para uma política agrícola vai amadurecendo. As constantes visitas aos Estados Unidos realizadas por técnicos comissionados e os contatos com a produção intelectual daquele país proporcionados pelas publicações oriundas de lá, fazem com que nossa elite se identifique com o progresso daquela nação e aperfeiçoe suas propostas para o Brasil tendo como referência a agricultura lá praticada.

A proposta política de Barreto de união dos fazendeiros em torno da recuperação da lavoura cafeeira se torna a política oficial do governo do Estado de São Paulo em 1904 com a eleição de Jorge Tibiriçá para o Governo de São Paulo e com a nomeação de Carlos Botelho para a Secretaria da Agricultura. A proposta modernizadora do governo Tibiriçá será objeto de pesquisa do próximo capítulo.

\subsubsection{Experiências modernizantes no início do século $\mathrm{XX}$.}

As experiências pioneiras de modernização da agricultura no Estado de São Paulo, segundo Carmo (1939), foram obras do Dr. Carlos Botelho, na Fazenda do Lobo e do Dr. Antônio Luiz dos Santos Werneck, no Banharão ${ }^{20}$, que abandonaram a foice e a enxada e colocaram em seu lugar máquinas aratórias. Na Fazenda do Lobo cultiva-se milho, feijão e alfafa, já no Banharão, onde não havia cafezais novos para os colonos plantarem milho entre suas fileiras, conforme o estabelecido pelo sistema de colonato, o próprio Gomes do Carmo, engenheiro agrônomo formado na França e funcionário do Instituto Agronômico de Campinas fora contratado para cultivar mecanicamente este cereal em quantidade e custo que exonerassem o proprietário de comprar milho de que seus colonos necessitassem.

Naquela época somente as colônias alemãs do Rio Grande do Sul e de Santa Catarina e Colônia de Vila Americana, formada por norte-americanos vindos para cá

\footnotetext{
${ }^{20}$ A Fazenda do Lobo localiza-se no município de São Carlos. Banharão era uma localidade na região de Bauru.
} 
após o término da Guerra de Secessão usavam instrumentos agrícolas modernos. Podemos observar o racialismo presente, pois todos agricultores que adotavam práticas evoluídas eram formados por raças consideradas superiores.

Havia no país apenas três publicações tratando de questões agrícolas: A Revista da Sociedade Auxiliadora da Indústria Nacional ${ }^{21}$, editada no Rio de Janeiro; o Jornal do Agricultor, editado também no Rio de Janeiro e a Revista Agrícola. Carmo considera este número de publicações insuficiente num país essencialmente agrícola.

Também o comércio de máquinas agrícolas, segundo Carmo (1939), era insuficiente. Havia Arens \& Cia que fabricava máquinas agrícolas em Jundiaí, e tinha lojas em São Paulo e no Rio de Janeiro; A Roger \& Cia, que atendia aos mercados de Minas Gerais, Rio de Janeiro e São Paulo; a firma inglesa Hopkins Causers and Hopkins, que também vendia incubadoras e máquinas para laticínios e as máquinas aratórias da casa M. M. King. Porém, afirma Carmo, poucas destas firmas prosperam.

No início do Século XX havia as casas Upton e Cia e a Leon \& Cia. A empresa Cia Mecânica Importadora, propriedade de Alexandre Siciliano e a Cia Mac Hardy, com sede em Campinas. Além destas encontrava-se apenas firmas de importância menor e fora do Sudeste, e apenas uma em Porto Alegre, a firma alemã Bromberg \& Cia.

A modernização da agricultura no final do século XIX e início do século XX eram portanto ainda muito insipiente. Mas em 1904, já se constituía num poderoso instrumental teórico nas mãos de intelectuais com a finalidade de transformar a realidade do país.

\subsubsection{A modernização: algumas reflexões.}

Após mostrar as vantagens dos métodos racionais de agricultura em relação aos métodos rotineiros, Carmo (1939) estabelece uma comparação entre os agricultores usuários dos dois métodos. O primeiro ele chama de homem do arado, o segundo de enxadeiro, de Jeca. Coloca-os a realizar o mesmo trabalho em condições idênticas e

\footnotetext{
${ }^{21}$ Sociedade Auxiliadora da Indústria Nacional, entidade com sede no Rio de Janeiro, formada por agricultores no final do século XIX, que editava o mensário citado. Carmo diz que ela era "de certo modo uma imitação da Sociedade Rural Argentina, com a diferença, porém, que esta quase só se compunha de criadores e lavradores, e a nossa Auxiliadora quase só encontrava em seu seio influências políticas, muitas delas sem ligação direta com a agricultura”. (Carmo, 1939, p.19).
} 
compara os resultados. O trabalho inicial é igual para ambos que terão de desbravar várzeas, fazendo roçadas, queimadas, coivaras, extrair tocos e raízes. Porém, o agricultor moderno na primeira colheita já terá vantagem: com o uso da carpideira fará uma colheita melhor que seu vizinho.

"No ano seguinte o enxadeiro estará a abrir novas roçadas, sempre com a mesma trabalheira; mas nosso agricultor do arado, grade e carpideira estará menos pobre e menos atarefado, porque cada gleba nova lavrada é trabalho feito e acabado; terá apenas que desbravar nova gleba para aumentar a primeira já roteada e, findo o lapso de tempo de uns cinco anos, o homem do arado já será um lavrador abastado com posição social, enquanto nosso enxadeiro será sempre o mesmo Jeca, tendo por único cabedal acumulado a miséria”. (Carmo, 1939, p.16)

A discussão que Carmo (1939) levanta é a do domínio sobre a natureza, o agricultor que usa máquinas agrícolas, que não precisa mais recorrer ao ferro e ao fogo da mesma forma que o enxadeiro dominou a natureza. Nos anos subseqüentes seu trabalho diminui porque ele não precisa mais estabelecer novas lutas contra outro trecho de florestas hostil para fazer sua roça. A natureza era entendida como um universo de barbárie que deveria ser transformada em favor da obra de civilização, na esperança da construção de um futuro de fartura e progresso e a ciência e a técnica seriam instrumentos que os homens usariam para cumprir tão árdua tarefa.

Segundo Murari (2002), o período moderno se apresenta como aquele em que a cultura nacional foi capaz de apresentar uma nova imagem da natureza. A ênfase dos discursos foi então colocada na técnica, como instrumento de mediação e de exercício de controle, exploração e aperfeiçoamento da natureza pelo homem, articulada à idéia de transformação profunda da sociedade e às utopias regeneradoras através das quais se achava possível construir um novo homem.

A modernização do país não estaria ligada somente ao uso das técnicas mas também à imigração, pois o imigrante já se mostrava um portador de novas formas de se trabalhar a natureza, um homem já disciplinado ao trabalho.

Sevcenko (2003) nos lembra que do contraste entre o Rio de Janeiro modernizado e o campo atrasado surge uma dicotomia entre campo e cidade, sendo o 
primeiro considerado atrasado. Esta dicotomia irá fazer parte dos debates nos anos seguintes. Murari (2002) acredita que a atualização da agricultura ajudava a defender o setor das pressões da industrialização e da urbanização, ao buscar criar uma nova racionalidade, que promovesse a superação dos métodos rotineiros e precários de produção e aumentasse a eficiência do sistema produtivo. A agricultura modernizada era vista como uma forma de civilizar a natureza e o homem bárbaro do sertão, tornando-os capazes de competir com seus adversários mais evoluídos: a cidade e a indústria. Podemos entrever nesta preocupação com a eficiência o utilitarismo inglês conforme descrito no primeiro capítulo.

A ciência promoveria o aproveitamento máximo dos recursos disponíveis, a terra e o homem. A técnica adquiriria um papel central na criação de uma moderna civilização rural que iria inserir o Brasil nos movimento de ampliação das fronteiras do capitalismo internacional. A ideologia da modernização representava, portanto, uma forma de romper a associação do rural com a barbárie, tornando-se o campo um espaço civilizado, onde o homem assumiria o controle dos elementos naturais - doravante pensado como recursos - perdendo assim o tom fatalista de origem darwiniana que associava o rural ao espaço de uma luta eterna contra o meio natural hostil.

A técnica, segundo Murari (2002), chegou a fundamentar uma espécie de messianismo rural, ao qual os seus defensores devotavam uma fé quase que infinita na superação da decadência e do atraso. Usavam-se termos retirados de uma imagética e de uma linguagem místico-religiosa: redenção, salvação, regeneração, libertação das trevas, ressurreição. Estes são alguns dos termos usados para descrever o sentido da conversão, que ironicamente, também é um termo místico, da ruína em progresso. Tais termos eram mais comuns aos romancistas, mas apareciam com uma certa freqüência nos artigos da Revista Agrícola e d'O Fazendeiro.

Entretanto, não somente as regiões onde a agricultura já era uma atividade praticada eram consideradas passíveis de transformação. De acordo com Murari (2002), também a natureza bruta havia de ser incorporada à civilização, integrada a ela através de novas tecnologias de transporte e comunicação, da intervenção no sentido da superação de obstáculos naturais à circulação de riquezas e recursos. A demanda pela 
modernização da agricultura era, portanto, apenas um dos aspectos de um projeto mais amplo, a noção de que a ciência poderia promover o controle do homem sobre a natureza, projeto que remonta ao renascimento europeu, com a obra de Francis Bacon, que não vamos abordar porque fugiria aos limites desta pesquisa. Basta dizer que desde Bacon não mais se concebia a vitória sobre a natureza pelo ferro e fogo, mas pela ciência e pela técnica. 


\section{DISCUSSÃO}

\subsection{A modernização da agricultura no governo de Jorge Tibiriçá (1904-1908).}

Em seu editorial de 15 de maio de 1904, com o título de "O novo governo de São Paulo”, a Revista Agrícola saúda o novo dirigente daquele estado: “A nossa Sociedade Paulista de Agricultura, Comércio e Indústria têm sobejos motivos para exultar de satisfação: todos os membros do atual governo de São Paulo saíram de seu seio.” (Revista Agrícola, 1904, p179). Estavam realmente exultantes! Jorge Tibiriçá fora eleito presidente do Estado ${ }^{22}$, Albuquerque Lins nomeado secretário da Fazenda, Cardoso de Almeida ocuparia cargo na Secretaria do Interior e Justiça e Carlos Botelho assumiria a pasta da Agricultura. Este último fora saudado com particular entusiasmo: foi na sua viagem à América do Norte e ao México "que o problema de nosso futuro econômico se assenhoreou por completo de seu espírito, não deixando-o mais descansar, e impelindo-o cada vez mais a se aproximar da solução.” (Revista Agrícola, 1904, p181). A conclusão é ainda mais esfuziante:

"A Revista Agrícola orgulha-se de ver como secretário da agricultura um de seus mais ilustres redatores e se desvanece em saudar reverentemente todos os ilustres cavalheiros que compõem o atual governo de São Paulo, vendo em seu conjunto a mais sólida garantia de ordem e progresso." (Revista Agrícola, 1904b, p.184)

\footnotetext{
${ }^{22}$ Jorge Tibiriçá era natural de Itu, SP., filho de Carlos Tibiriçá de Almeida Prado. Em sua residência realizou-se o histórico encontro de Republicanos paulistas em 1870, conhecida por Convenção de Itu. Proprietário de fazendas de açúcar e posteriormente de café, foi um dos proprietários da Estrada de Ferro Ituana. Regressou da Europa “em 1879 formado em Ciências químicas e doutor em filosofia pela Universidade de Zurique, além de engenheiro agrônomo formado pela famosa Universidade de Hohenhein.” (Soares, 1958, p.346).
} 
Bottelho fora saudado por todo o Estado. O Douradense, jornal da próspera cidade de Dourados saúda com grande expectativa o novo secretário da agricultura a promessa de novos tempos.

"Pois sabemos ser ele um dos poucos que conhecendo bem a economia yankee, compreendem bem que para entrarmos em luta com rivais (...) precisamos produzir barato; para isso necessitamos de ciência agrícola, bons maquinistas e práticas para manejá-los. A técnica hoje é tudo, foi-se o tempo do escravo; o cálculo tem de entrar em ação sob pena do insucesso." (Revista Agrícola, 1904c, p.198)

Perissinotto (1994) afirma que no governo Jorge Tibiriçá a Sociedade Paulista de Agricultura - SPA, que editava a Revista Agrícola assumiu o controle da política cafeeira, ou seja, temos um novo grupo no poder, uma nova fração da classe dominante, que representa o grande capital cafeeiro ${ }^{23}$, de tendências modernizantes.

Entendemos ser importante caracterizar este projeto, pois nas poucas referências bibliográficas existentes sobre o assunto o tema é tratado de maneira bastante genérica, com apenas algumas abstrações do ponto de vista da política econômica mais ampla, pouco se referindo ao que se fez de concreto para mudar a vida da agricultura do Estado e do país.

O projeto de Carlos Botelho incluía a utilização de maquinário agrícola, combate ao desgaste do solo, portanto, da agricultura itinerante, diversificação da agricultura, política de formação de colônias agrícolas com subvenção estatal como forma de fixar os trabalhadores nas proximidades das fazendas, ensino agrícola, substituição de importações, expansão da rede ferroviária.

Nas páginas seguintes vamos abordar algumas atividades concretas da Secretaria da Agricultura no sentido da modernização.

\footnotetext{
${ }^{23}$ Segundo Saes (1986), o grande capital era formado por atividades rurais e urbanas, isto é, agrícolas, industriais, ferroviárias, comerciais e bancárias. As grandes famílias paulistas em geral tinham participação em mais de um ramo de atividade.
} 


\subsubsection{Distribuição de mudas e sementes}

Uma das preocupações do governo Tibiriçá foi a distribuição de mudas e sementes. Durante o primeiro ano de seu mandato, em 1904, o governo paulista distribuiu 63.683,7 Kg de sementes para os agricultores paulistas, sendo a maior parte importadas, com a finalidade de melhorar a qualidade da lavoura e também de diversificá-la, e 187.749 exemplares de mudas de plantas, em sua maioria frutíferas. O mesmo serviço continuou a ser realizado nos anos subseqüentes.

Em 1905, já em novas e modernas instalações, foram criadas estufas para avaliar “a capacidade germinativa das sementes”, com a finalidade se distribuir sementes de melhor qualidade. Outros aparelhos foram encomendados "para facilitar o completo exame das sementes antes de serem entregues aos lavradores.” (Botelho, 1905, p.7).

Distribuir sementes como vinha sendo feito até então não era mais suficiente, agora era preciso distribuir sementes tratadas cientificamente; interessava somente aquelas com maior poder de germinação.

Segundo Botelho (1907), no ano de 1907, ampliam-se os fornecedores de plantas vivas e sementes. Além do Instituto Agronômico, assumem o encargo a Fazenda Modelo da Escola Agrícola Prática Luiz de Queiroz, o Campo de Experiências do Núcleo Campos Sales, o Campo de Demonstração da Cultura do Arroz de Moreira Cezar. Diminui-se, portanto, a quantidade de sementes vindas de fora, embora a autosuficiência estivesse ainda distante.

\subsubsection{Propaganda agrícola}

A disponibilização de informações continuou tendo um papel importante na nova administração. O Boletim da Agricultura (Botelho, 1905, p.VI) continuou sendo publicado. A coleção completa relativa àquele ano se constitui num volume com 606 páginas e contêm dados oficiais sobre a agricultura, muitos dados estatísticos (cotações do café e outros produtos), informações meteorológicas, informações de interesse geral e trabalhos de propaganda de conhecimentos úteis à lavoura. 
Os artigos são claramente um incentivo à diversificação da agricultura, à melhoria da produção através do uso de novas técnicas agrícolas e de maquinário. Em 1904, foram distribuídos 2.987 exemplares, mensalmente, da seguinte forma:

Tabela 1. Distribuição do Boletim Agrícola (1904)

\begin{tabular}{lr}
\hline Distribuição & exemplares \\
\hline Grátis & 2.232 \\
A pagamento & 15 \\
A repartições públicas & 140 \\
Para permutas do Instituto Agronômico com & \\
instituições congêneres & 600 \\
\hline Total & 2.987 \\
& Fonte: Botelho (1905)
\end{tabular}

Destes Boletins, 2.101 ficaram no Estado de São Paulo, 100 foram enviados a outros estados e 46 ao exterior. É interessante ressaltar que mais da metade dos impressos era distribuída gratuitamente a moradores do Estado, associações agrícolas, científicas e a cônsules brasileiros. Foi através das trocas pelo Boletim Agrícola que o Instituto Agronômico de Campinas formou sua biblioteca.

O Boletim da Agricultura era considerado um "meio eficaz de difundir instrução”, e ocupava uma atenção especial, "principalmente enquanto o Estado não possui instituições de ensino disseminadas pelas diferentes zonas.” Há, contudo, uma queixa em relação à falta de autores especializados. Escritores existem, "porém poucos são os que se identificam com o caráter especial que devem ter os escritos com caráter de propaganda” (Botelho, 1905, p.VI). Talvez possamos levantar a hipótese de que o que faltava eram bons especialistas identificados com o objeto da propaganda, isto é, com a agricultura científica.

Em 1905, fora criado o boletim Criador Paulista, destinado aos interessados em pecuária. Também se iniciou a publicação de outro boletim: Estatística do Commercio do Porto de Santos com os Paizes Extrangeiros, que obviamente registra todo o movimento daquele porto, de Ubatuba e de Iguape. Na realidade, ocorre um 
desdobramento do Boletim Agrícola, que deixara de publicar matérias relativas àqueles assuntos o que explica a diminuição da quantidade de matérias e páginas publicadas.

Dentre estas publicações convém notar ainda um número relativamente alto daquelas destinadas à propaganda das qualidades do Brasil e das imensas possibilidades que o país oferecia para atraír imigrantes. Algumas foram publicadas em línguas estrangeiras e distribuídas pelas embaixadas brasileiras no exterior. Estes informativos impressos, portanto, são bastante coerentes com a proposta de governo de Jorge Tibiriçá, que é a de modernização da agricultura.

\subsubsection{Campos de experiências e de demonstração.}

Os campos de experiências e demonstração sempre foram considerados fundamentais como instituição de educação informal onde o agricultor pudesse ver na prática como se dão os processos agrícolas e o manejo de novos instrumentos.

Em 1904, nos campos de demonstrações do Instituto Agronômico de Campinas, instituição imperial, criada por D. Pedro II, mas que fora prestigiada pelo novo regime, realizaram-se experimentações:

"Sobre estrumação, poda e hibridação de cafeeiros, iniciadas já há cerca de cinco anos, bem como as de mais recente data sobre alfafa de sementes espinhosas, inoculação do solo, culturas de variedades novas de algodão, seleção de cana de açúcar, cultura de trigo e cevada, poda das videiras, além de inúmeras outras de importância secundária.” (Botelho, 1905, p.26).

Em 1905 fora criado o Campo de Demonstração de Culturas Rasteiras de Nova Odessa, junto ao núcleo colonial do mesmo nome. Este campo era vinculado ao Instituto Agronômico.

No Campo de Experiências de Iguape, as experimentações eram realizadas com arroz, cultivo importante da região. Também com o cacau, linho, juta e mamona, tendo ainda prosseguido experiências com o preparo da baunilha. O objetivo dessas experiências era produzir alternativas à cultura do café que "ali encontra uma longa série de condições desfavoráveis, que determinam a ruína de muitos agricultores.” (Botelho, 1905, p.41). 
Em Sorocaba, as principais experiências foram com o algodão que há um bom tempo fazia a riqueza daquela região. Também fizeram experiências com galinhas da terra "com o fim de formar uma variedade que se distinga pela abundância de seus ovos e qualidade de sua carne, e possa ser criada sem grandes cuidados.” (Botelho, 1905, p.42). Realizaram também experiências com estrumação e com o plantio de essências florestais nativas.

\subsubsection{Horto Agrário Tropical, em Cubatão}

Segundo Botelho (1906), no ano anterior foi criado o Horto Agrário Tropical, em Cubatão com a finalidade de produzir mudas e aclimatar plantas para o clima quente do litoral. Foram feitas experiências com cacau, baunilha, arroz, fumo, sorgo, mamonas de Zanzibar, cravo da Índia, pimenta do reino etc. A banana, a juta e outras plantas têxteis mereceram destaque. Estavam preparando os experimentos com o coco da Bahia. Todos os produtos plantados por estes cultivadores eram importados pelo Estado, principalmente a juta, que tinha largo emprego na sacaria para embalar café. Este é outro aspecto da agricultura moderna: a substituição de importações. A diversificação da agricultura implicava também em se dar utilidade econômica a áreas onde não era possível de se plantar café. Havia na proposta de modernização a necessidade de se respeitar as características naturais de cada região, o que será feito também com o arroz no Vale do Paraíba.

Em 1906, fora criado o Campo de Demonstração da Cultura do Arroz, em Moreira Cezar, no Vale do Paraíba, região decadente em virtude do declínio da cultura cafeeira. O objetivo era incentivar a cultura do arroz no Vale do Paraíba de Jacareí para baixo, isto é, até as proximidades das divisas com o Estado do Rio de Janeiro. Com a dificuldade de se encontrar mão-de-obra especializada no Brasil recorre-se ao estrangeiro. Fora contratado o Senhor Welman Bradford, do Estado da Louisiana, nos Estados Unidos da América, para dirigir os trabalhos. O objetivo era introduzir “processos mais racionais na cultura do arroz” (Botelho, 1907, p.30). Este deveria ser um estabelecimento modelo de propaganda agrícola destinado aos interessados naquela cultura. 
A cultura de arroz obtém imenso sucesso por conta dos processos científicos, espalhando-se por outros pontos do Estado (Itu, Itapira) e até mesmo chegando a Campos, no Estado do Rio de Janeiro. E o Estado de São Paulo se torna praticamente auto-suficiente em arroz. Além do aspecto econômico, a substituição de importações de produtos agrícolas, notadamente do arroz, era também considerada fator de saúde pública, pois nos navios ${ }^{24}$, junto com os carregamentos, vinham pequenos animais e insetos portadores e transmissores de doenças.

"Se é verdade que o arroz é um bom alimento para os homens, também é um certo ser um regalo para os ratos, veiculadores das pulgas, as quais, segundo a última concepção científica, nos inocula o vírus da peste bubônica. Arroz, rato e pulgas formam essa tríade mortífera que cessamos de importar depois que passamos a viver exclusivamente de nosso arroz, cuja cultura, sabeis, incrementou-se com a irrigação.” (Botelho, 1912, p.841)

É notável perceber nas falas de nossos intelectuais da época o horror a doenças que hoje não nos causam mais medo. O higienismo ao descobrir as causas e os meios de transmissão das doenças servia também para organizar a produção agrícola de modo a promover o bem estar humano. O controle destas doenças era promessa de felicidade.

\subsubsection{Instituto Agronômico de Campinas}

A aplicação de conhecimentos científicos na agricultura era outra prioridade do projeto modernizador, tarefa esta realizada com maior intensidade nos gabinetes e laboratórios do Instituto Agronômico de Campinas. A preocupação era com entomologia para o combate de pragas, análise de solo e produtos agrícolas. Em 1905, o Instituto Agronômico continua a cumprir esta função. Fora projetada a publicação de um Annuário, onde seriam divulgados todos o trabalhos desenvolvidos na Instituição, e até onde sabemos, tal projeto não foi concretizado. Em 1906, o diretor do Instituto, Gustavo D’Utra viajou comissionado para a Europa e Estados Unidos para estudar ensino

\footnotetext{
${ }^{24}$ Barreto (1903b) considerava que a peste bubônica estava relacionada à monocultura o que facilitava a proliferação de ratos, os vetores da peste.
} 
agrícola. No ano seguinte fora contratado na Europa o senhor Max Passon, que chamou para seus auxiliares os senhores João Hermann e Alfredo Lehman.

A onda modernizante chega ao Agronômico, embora a própria natureza de seu trabalho já fosse moderna, com a intensificação da aplicação da ciência à agricultura.

O Agronômico começa a se destacar como produtor de mudas e sementes, na medida em que os trabalhos nos campos de demonstração vão sendo associados aos trabalhos de gabinetes e laboratórios. A teoria começa a ser unida à prática. Sua biblioteca torna-se centro de referência em agricultura contando, em 1906, com 6.751 volumes em sua maioria obtidos em trocas pelo Boletim da Agricultura, produzido também com esta finalidade.

\subsubsection{Horto Botânico}

No Horto Botânico, a preocupação central era com a aclimação, aclimatação diríamos hoje, produção e distribuição de mudas de plantas frutíferas exóticas. Em 1905, inicia a criação de carpas, espécie de peixe que fora introduzido nos tanques do Horto e que "pareceu se adaptar muito bem” (Botelho, 1906, p.38). Nos anos subseqüentes do governo Tibiriçá, o Horto Botânico continuará tendo como prioridade a produção de frutíferas e ornamentais, tais como dálias e hibiscos. Somente a partir de 1910, quando Navarro será nomeado seu diretor, que ele tornar-se-á um grande centro produtor de mudas de eucaliptos.

\subsubsection{Posto Zootécnico Central}

Em 1906 fora criado o Posto Zootécnico Central. Para dirigir este posto fora contratado o Senhor Hector Raquet, médico veterinário belga, catedrático da Escola Agrícola de Gembloux. A falta de bons profissionais identificados com a proposta modernizadora estava sempre presente. Importam-se animais de raças européias para melhoria do rebanho, discute-se qual o processo para a formação do novo rebanho nacional: cruzamento com gado caracu ou selecionamento visando o aperfeiçoamento da raça, mas ainda não tomam decisão final.

Pestana, já em 1923, reconhece a importância da criação deste posto: 


\begin{abstract}
“(...) Somente em 1904 veio a pecuária a despertar a atenção em plena crise do café.(...) o Dr. Carlos Botelho empenhou-se em promover o adiantamento da indústria pastoril. Facilitou a introdução de animais reprodutores de boas raças européias, procurou aclimá-las e cruzá-las com gado indígena, levou a efeito a exposição de animais, etc. $E$ de tal arte, despertando o interesse de particulares, contribuiu inteligentemente para a melhoria de nossos rebanhos, que definhavam.” (Pestana, 1923, p.20)
\end{abstract}

Melhoram a qualidade das plantas forrageiras, inclusive usando diversos tipos de adubação, bem como se constrói o primeiro silo do país, seguindo o modelo norte americano, para se armazenar o milho cortado verde. No setor de laticínios foram compradas máquinas nos Estados Unidos e na Inglaterra, que são acompanhas por duas alunas do curso de laticínios. É a primeira vez que constatamos a presença feminina num estabelecimento ligado ao campo. Finalmente estabelecem os registros para que as experiências não se percam: Herd-book, Stud-book, Peg-book e Flock-book

\title{
5.1.8 Serviço Meteorológico
}

O Serviço Meteorológico, órgão diretamente subordinado à Secretaria da Agricultura, contava com quarenta postos de observação com o fim de verificar a marcha dos elementos climatológicos sobre a agricultura. Haverá ao longo do mandato de Tibiriçá melhoria na divulgação dos resultados de suas pesquisas atingindo um maior número de lavradores.

\subsubsection{Galeria de Demonstração de Máquinas}

Em 1905 também foi criada a Galeria de Demonstração de Máquinas no andar térreo do prédio no Largo de São Francisco, em São Paulo, na Capital. Foram expostas máquinas para beneficiamento de arroz e café de diversos fabricantes nacionais. Durante duas horas por dia essas máquinas eram mostradas em total funcionamento aos fazendeiros interessados que se deslocavam até lá para verem as vantagens que seu uso oferecia e para que pudessem aprender a manejá-las. Havia também um celeiro com os produtos necessários para as demonstrações de seu funcionamento (arroz, café, milho, etc.). Em 1906, cresce o número de visitantes e de vendas. Alunos de cursos de 
engenharia visitam a casa de demonstração, o que é importante porque futuros engenheiros representam elementos difusores de novas concepções de agricultura e de beneficiamento de produtos agrícolas. Eram, como diríamos hoje, os agentes multiplicadores das vendas, pois incentivariam seus patrões a fazerem uso delas.

\subsubsection{Terras devolutas e colonização do território}

Outra questão importante que o Estado teria de resolver era o problema das terras devolutas. Por lei ${ }^{25}$ todas as terras doadas por sesmarias, posses ou outras formas de concessões deveriam ser legitimadas ou revalidadas dentro de um determinado prazo. Uma vez esgotado este prazo, as terras seriam devolvidas ao Estado e seriam revendidas a particulares.

Como os prazos para a regularização das terras se esgotaram havia muito tempo, era tarefa urgente fazer um diagnóstico sobre quais terras estavam em situação irregular para providenciar sua devolução para o Estado, que daria a elas uma finalidade ou promoveria sua venda a particulares. Seria esta uma fonte nada desprezível de recursos. Em 1906, os trabalhos de regularização destas terras devolutas continuam, porém em ritmo lento devido à precariedade dos caminhos, pois os técnicos teriam de se deslocar até elas para fazer a demarcação exata.

Relacionada ao problema das terras devolutas, estava a questão de colonização do território, isto é, de empreender "o povoamento de nosso solo, atraindo e fixando os elementos para a multiplicação de suas riquezas” (Botelho, 1904, p.131). A temática, porém, adquire no Governo Tibiriçá um significado bem preciso, moderno, pode-se dizer. Pretendia-se trazer imigrantes estrangeiros e dotá-los de pequenos lotes de terra, isto é, torná-los proprietários para que eles pudessem produzir gêneros para consumo próprio e para o mercado interno.

\footnotetext{
${ }^{25}$ As leis eram: Decreto n. 734, de 5 de janeiro de 1900, que consolidou as disposições contidas nas Leis n.323, de 22 de junho de 1895, n.545, de 2 de agosto de 1895, n.545 de 2 de agosto de 1898, e n. 655 de 23 de agosto de 1899. (Botelho, 1905, p.2)
} 
Para promover o novo tipo de colonização o Estado recorre à parceria com a iniciativa particular. Nesta parceria o governo entra com a terra e o lavrador-empresário e parceiro com o capital. O resultado das vendas aos imigrantes ou aos trabalhadores livres nacionais seria repartido proporcionalmente. Opta-se por agir com cautela. No primeiro ano, somente duas novas colônias estão em planejamento e ambas ao longo da Cia Paulista de Estradas de Ferro, cuja localização se justifica em função da necessidade de aumentar a circulação de mercadorias e de pessoas, o que aumentaria o fluxo de transportes para a estrada de ferro. Além, é óbvio, da valorização da região como um todo devido à presença de braços para a lavoura e para a própria ferrovia, a disponibilidade de gêneros por eles produzidos (cereais, algodão, cânhamo, fumo, e outros) também era um fator de valorização da região.

Entretanto, a questão central era a necessidade de se fixar os colonos no campo para que fosse possível a transformação das relações de produção nas fazendas. O novo sistema
"poderá concorrer bastante para o estabelecimento dos viveiros dos trabalhadores, fixando o imigrante, permitindo a transformação do sistema de trabalho na grande lavoura cafeeira, diminuindo o ônus do custeio tão elevado pela necessidade de sustentar durante o ano todo o colono" (Botelho, 1904, p.135).

O Governo Tibiriçá, portanto, inova mais uma vez no sentido da modernização. Ao contribuir para a fixação do colono no campo ele estará, na verdade, criando um novo tipo de relação de produção na lavoura. Como nas lavouras de café, a exigência de um maior número de trabalhadores ocorre somente na época da colheita, isto é, trata-se de um trabalho sazonal. Sendo assim, o fazendeiro fará uma grande economia nos outras etapas da produção, quando haverá diminuição da mão-de-obra, tirando de si o encargo de sustentar o colono nos momentos em que ele não estiver sendo necessário. O colono estará trabalhando em suas próprias terras produzindo para seu próprio sustento. As relações de trabalho no campo tornar-se-ão plenamente capitalistas valendo entre ambas as partes somente o contrato de trabalho, mediado pela moeda. 
Quanto à colonização das terras devolutas, ela seria permitida apenas nos casos em que estivessem às margens das ferrovias, caso contrário a colônia somente seria criada se houvesse um projeto de construção de nova ferrovia que chegasse até ela. $\mathrm{O}$ Estado dará "garantia de juros e terras marginais, dentro de uma faixa de cada lado da linha, com a obrigação da empresa de retalhá-la e colonizá-las, reservando-se o Estado sempre um lote, alternadamente." (Botelho, 1904, p.135). O fornecimento de mão-deobra para as fazendas é prioridade em relação ao povoamento do território e a produção de gêneros para mercado interno. Tanto é que não se privilegiam a produção de gêneros alimentícios de produção anual, que não fixam o homem à terra, mas sim o plantio de árvores frutíferas e de essências florestais, as quais os colonos ficariam ligados por longos anos.

Para viabilizar financeiramente novos projetos de colonização, propõe 0 Governo, a criação de um fundo de colonização formado pelo empréstimo de um milhão de libras esterlinas, pelo dinheiro arrecadado das vendas das terras devolutas, à medida que elas vão sendo discriminadas, pelos recursos advindos do pagamento da compra dos lotes feito pelas empresas colonizadoras nas áreas particulares ou pelos colonos nas áreas de colonização estatal e pelas importâncias novamente concedidas pelo Congresso Legislativo, ou seja, por recursos advindos do tesouro público, quando se fizer necessário novos recursos. Sugere ainda a criação de um imposto territorial, que seria mais elevado perto das grandes cidades e das ferrovias para estimular a divisão das grandes propriedades incultas.

Segundo Botelho (1906), no ano anterior foram criados mais dois núcleos coloniais: O núcleo Jorge Tibiriçá, na fazenda São José do Corumbataí, no município de Rio Claro e o núcleo colonial de Nova Odessa, para o estabelecimento de colonos russos. Este último nasceu com algumas vantagens sobre o anterior, haja vista que naquele houve muitas desistências. Em Nova Odessa foram reservadas terras para a criação de um campo de demonstrações agrícola, que ficaria sob o encargo do Instituto Agronômico de Campinas; criou-se um engenho para beneficiar produtos agrícolas, que funcionaria cobrando preços de custeio, apenas; fora criado também um posto zootécnico que mantinha um plantel de reprodutores a ser usado pelos colonos 
interessados em melhorar a qualidade de suas crias; um estoque de instrumentos e máquinas agrícolas mais usuais; animais de trabalho e veículos que serão alugados aos colonos durante seu primeiro ano agrícola. Terão também transporte ferroviário gratuito caso queiram trabalhar nas fazendas de café. O objetivo era evitar o abandono dos lotes tal qual ocorrera no Núcleo Tibiriçá. O Núcleo Campos Sales foi, naquele ano, ampliado. Os demais Núcleos não sofreram alterações.

Em 1906, segundo Botelho (1907), foram adquiridas terras para a instalação de mais três núcleos coloniais com cerca de dois mil alqueires cada: Gavião Peixoto, Nova Europa e Nova Paulicéia, sendo os dois primeiros hoje municípios na região de Araraquara. O prolongamento da Estrada de Ferro de Dourados deveria viabilizar o estabelecimento destas colônias. No município de Ubatuba também foram adquiridas terras para a instalação da colônia Mato Dentro, mais tarde chamada Conde do Pinhal, em homenagem ao pai do secretário. Os trabalhos de colonização continuam em 1907 com a retaliação das fazendas do Funil, São Bento e Boa Vista em parceria com a Usina Ester, do Coronel José Paulino Nogueira. Tem início também o processo de retaliação da Fazenda Quilombo ${ }^{26}$, em parceria com Luiz Antônio Queiroz, no então município de Campinas.

Em $1907^{27}$, foi criada a Diretoria de Terras, Colonização e Administração para tratar de todos os assuntos referentes ao desenvolvimento de uma política de povoamento e colonização. A necessidade da criação deste órgão dá uma noção da importância deste aspecto para o projeto modernizante, pois as colônias agrícolas já seriam concebidas e constituídas como modernas tornando-se demonstrativas das vantagens da agricultura científica.

Ainda no que se refere ao povoamento do Estado continuou, pela Commissão Geographica e Geológica, o trabalho de criação das “Cartas do Estado” tendo sido mapeados os municípios de Pirassununga, Casa Branca e Pindamonhangaba. Porém, as atividades mais importantes foram as expedições realizadas aos Rios Feio e do Peixe e outra ao Tietê-Paraná, ambas no oeste do Estado. O objetivo era conhecer os rios citados

\footnotetext{
${ }^{26}$ Hoje ocupando parte dos municípios de Hortolândia, Sumaré e Americana.

${ }^{27}$ Decreto N ${ }^{\circ} 1459$, de 10 de abril de 1907.
} 
e seus afluentes, o potencial hidrelétrico por eles apresentados e avaliar a qualidade das terras da região, bem como os obstáculos para o transporte de pessoas e mercadoria.

Em ambas as expedições foram encontrados índios, sendo que na expedição dos Rios Feio e Peixe tiveram problemas com os coroados, hoje chamados Kaingang, que atacaram canoas e acampamentos em diversas oportunidades, mas ninguém se feriu (Botelho, 1906, p.208-210). Estes índios apresentaram imensas dificuldades para o estabelecimento de fazendeiros na região, principalmente por ocasião da implantação da Estrada de Ferro Noroeste. Com tempo estas resistências foram vencidas ao custo de muito sangue derramado.

O trabalho da Commissão Geographica e Geológica de exploração das diversas regiões do Estado nos anos seguintes foi intenso: teve prosseguimento a exploração do extremo sertão, como era conhecido o oeste do Estado $^{28}$, e iniciou o reconhecimento das regiões do Litoral Norte do Estado e do Vale do Ribeira.

Estas realizações denotam um esforço no sentido da transformação de processo produtivo, transformar os métodos até então rotineiros de práticas agrícolas em agricultura científica capaz de produzir a preços competitivos no mercado internacional $^{29}$.

À guisa de conclusão podemos afirmar que existe uma absoluta coerência entre as propostas políticas da classe empresarial da época, conforme expressas no anteriormente e as realizações do Governo Jorge Tibiriçá, eleito como representante dos empresário na área agrícola. Fica-se até com a impressão de que tudo que se refere á modernização da agricultura foi feito no Governo Tibiriçá. Há uma grande coerência entre as propostas de governo e as realizações na área agrícola.

\footnotetext{
${ }^{28}$ Outro cognome daquela região era sertão desconhecido. A Região de Campinas era chamada de Oeste paulista e Aparecida era do norte porque ainda naquela época o referencial era o Porto de Santos. A estação de trem da Capital que recebia os passageiros chegados do Vale do Paraíba e do Rio de Janeiro era chamada de Estação do Norte, hoje Roosevelt.

${ }^{29}$ Não podemos esquecer de relacionar também as substituições de importações, melhoria dos rebanhos eqüino e bovino, na criação de alternativas para as áreas onde o café não era rentável e na questão do povoamento do território paulista.
} 
Porém, para que estas transformações saídas dos gabinetes dos políticos ganhassem efetividade seria preciso que os lavradores fossem informados sobre tais processos e instruídos em como praticá-los, quer dizer, seria preciso criar modernas escolas agrícolas para este fim. No próximo capítulo estudaremos o papel da educação, mais especificamente da Escola Prática Luiz de Queiroz, no processo de modernização no campo.

\subsection{A ESALQ na gênese da agricultura científica.}

A importância da Escola Prática de Agricultura Luiz de Queiroz reside no fato dela ser a entidade que viabilizará a implantação do projeto de modernização da lavoura no Estado de São Paulo. Somos categóricos neste ponto: sem a Escola Prática de Agricultura de Piracicaba o governo Tibiriçá não lançaria as sementes da agricultura racional neste Estado.

No capítulo anterior verificamos algumas premências da agricultura racional: necessidade de desenvolver processos científicos, de novas tecnologias, de difusão destes novos procedimentos através da mídia de então, de formação de pessoal qualificado para suprir a demanda existente em quase todos os setores ligados à agricultura $^{30}$. Murari (2002), fala da necessidade da criação de um fazendeiro novo, tipo perfeito do homem de ação, inteligente e enérgico, empreendedor e ativo, para o qual qualquer tipo de crise era acidental e não desastrosa, pois ele possuía o instrumento correto para combatê-la: a técnica.

Podemos apontar ainda a necessidade de criação de um novo tipo de trabalhador, um homem novo, capaz de lidar com as novas tecnologias e novos processos agrícolas muito diferente do escravo que fizera todo o trabalho agrícola anos antes da abolição, ou do Jeca Tatu, o caboclo doente e ignorante, que compunha os então chamados agregados às grandes fazendas. Caboclo é uma denominação baseada em critérios raciais. A agricultura científica não atingiria, portanto, apenas os fazendeiros e a produção, mas

\footnotetext{
${ }^{30}$ Somente no Serviço Meteorológico e no Horto Botânico, não se contratam diretores vindos do exterior e são os dois órgãos que menos sofrem mudanças na direção de seus trabalhos.
} 
também os camaradas que nela trabalham e os pequenos agricultores, que embora não se tornarem agrônomos, terão de ser educados na escola primária regular ou informalmente, isto é por meios não escolares, para os novos tempos em que precisarão manejar instrumentos, fazer cálculos e outras operações que exigirão mais do que a simples força física. Estamos diante de um processo de mudanças globais, as quais darse-ão lentamente.

Vamos agora empreender uma descrição das reformas introduzidas na Escola Prática de Agricultura Luiz de Queiroz pelo governo de Jorge Tibiriçá, que renovou o ensino e a pesquisa sobre agricultura em sua época, missão esta que a ela continua a cumprir até nossos dias com o mesmo brilho de outrora.

No ano letivo de 1904 haviam matriculado na Escola 5 alunos no primeiro ano, 7 no segundo e 5 no terceiro. Formaram-se os cinco alunos do último ano. As causas do insucesso escolar foram várias: atritos entre os diretores da Fazenda Modelo e da escola, que só cessaram com a rescisão do contrato do primeiro e com o fato da Fazenda Modelo voltar a ser subordinada ao Diretor da Escola, sendo esta, portanto a primeira reforma. No segundo semestre, depois de sanadas as causas dos problemas existentes, as aulas práticas na fazenda foram sofríveis e as aulas foram no seu conjunto regulares.

Queixavam-se, os professores, da falta de compêndios, mas que todas as cadeiras já tinham adotado, para as outras se adotou um mimeografo, para não se perder tempo fazendo cópias. Havia deficiências de materiais nos laboratórios para as aulas práticas de diversas disciplinas. Todas as dificuldades foram diagnosticadas e providenciadas soluções.

No ano seguinte trinta alunos serão matriculados no primeiro ano, mas somente 12 passarão ao segundo. O curso não é serial de três anos, mas de três graus, que juntos perduram três anos, sendo que o primeiro é um curso voltado aos lavradores que trabalham diretamente na terra, no segundo se formam pessoas capacitadas para administrar grandes fazendas e no terceiro formam-se os agrônomos propriamente ditos. Ainda existem as especializações para os formandos que se destacaram e por último, bolsas de estudos no exterior. Portanto, o fato de haver menos matrículas no grau 
seguinte, não pode ser considerado fracasso escolar, mas o fato de haver grande quantidades de reprovados e evadidos dentro de uma série, sim.

Todos estes investimentos e mais outros que virão tinham um objetivo claro, transformar a Escola Prática de Agricultura Luiz de Queiroz num centro de referência:

"Se não um modelo no gênero, pelo menos uma norma para outros que devam ser fundados para facilitar a difusão dos conhecimentos práticos da agricultura racional, em todo território do Estado" (Botelho, 1904, p.6).

A Escola tinha portanto como objetivo a difusão dos princípios da agricultura racional. A ciência forneceria ainda recursos para a restauração das condições de produção desgastadas pelo uso predatório, as chamadas terras cansadas, recuperação da umidade perturbada pelos desmatamentos, correção do solo, irrigação das áreas secas e drenagem das insalubres.

Iniciam-se as obras do internato, para facilitar a freqüência às aulas. Contrata-se nos Estados Unidos o professor J.W. Hart, da universidade de Illinois, que assumirá o cargo no ano seguinte. Inicia-se a escrita da Fazenda Modelo, na qual "cada planta tem sua conta individual, desde o preparo do solo até o celeiro e o consumo" (Botelho, 1904, p.6). Criou-se também um arquivo de cada planta com uma ficha que registra pequenos históricos de cada exemplar, respondendo a questões de interesses práticos. Iniciam-se as obras do posto zootécnico.

O diretor da Fazenda Modelo informa que a aparência geral era boa, mas havia um aspecto de abandono. Vale a pena fazer transcrição da descrição do estado da Escola porque para quem conhece a ESALQ hoje é difícil imaginar que ela já esteve assim

"As matas eram constantemente invadidas por matilhas de cães veadeiros, diariamente, devastadas, por grande quantidade de gente em busca de lenha e madeira; os cultivados servindo de vez em quando de pastos a animais fugitivos da cidade e circunvizinhanças; os pastos sujos e mal seguros, ocupados quase que exclusivamente por animais de camaradas, alguns dos quais aqui já não trabalhavam, as maquinas agrícolas desmontadas umas, quebradas outras e outras abandonadas, muitas delas sem nunca terem sido ocupadas; casas de empregados em abandono, utilizadas até mesmo por pessoas estranhas ao serviço e com todas as vidraças estilhaçadas à pedradas, etc. etc. (Botelho, 1904.p.8.). 
Em pouco tempo tudo fora regularizado e outras obras iniciadas. Segundo o Relatório do Secretário da Agricultura de 1905, a Fazenda Modelo já estava completamente instalada. Ficando faltando apenas a conclusão das obras da escola.

O total da área plantada era de 80 hectares, ocupados com 32 culturas diferentes. Plantou-se também o primeiro cafezal da Fazenda.

Conforme podemos notar havia clareza a respeito da função social desta escola, que era de servir de modelo de escola de agricultura racional e coerência, embora ainda insipiente, entre o que se propunha e aquilo que efetivamente se realizava no sentido de torná-la moderna e eficiente.

Em 1905, a novidade foi o início das obras do internato e dos anexos, que hoje conhecemos como "Edifício Central", embora bastante modificado pelas reformas subseqüentes. A novidade pedagógica foi a introdução de visitas às fazendas e fábricas próximas e a fazendas em locais distantes, tais como as fazendas de café de Ribeirão Preto, nas férias do meio do ano. Para minorar a freqüência às aulas práticas cogita-se, além da construção do internato, a expansão dos trilhos da Estrada de Ferro Sorocabana até a Fazenda Modelo. Inicia-se também a construção do grande parque junto ao edifício principal para facilitar a alimentação dos apiários ainda em instalação.

Para a cadeira de agricultura, fora contratado na Bélgica o Sr. Louis Misson, que também colaborará junto ao Posto Zootécnico Central na Capital.

Em 1906, o edifício da Escola, que além do internato, comportava salas de aula, laboratórios, gabinetes, museus, etc. ficou pronto, embora tenha sido inaugurado somente em maio de 1907. O parque estava quase terminado e contrataram-se os especialistas em apicultura. Foram ao longo dos quatros anos de governo construídos também:

"o posto zootécnico, as pocilgas, o depósito de maquinas agrícolas, residência para o administrador da fazenda modelo, as oficinas, a residência para o diretor da escola, a casa das máquinas, o apiário e a vacaria (Botelho, 1907, p.X).

Do ponto de vista pedagógico as excursões a locais tidos como referências na prática da agricultura científica prosseguem e o número de visitas é ampliado. Vale a 
pena transcrever o roteiro de uma delas para que se tenha uma idéia do dispêndio de energia, tempo e dinheiro nelas envolvidos.

“Em fins de julho (...) seguiu uma turma (...) visitando na Capital, o Horto Botânico, Posto Zootécnico Central, Jardim d'Aclimação e Escola de Pomologia.

Realizada pela mesma turma a visita da exposição de animais de Pindamonhangaba, seguiram os alunos para o Horto Tropical Agrário de Cubatão e voltando de lá também visitaram a destilaria de Várzea, as culturas de mandioca em Itatiba, o Instituto Agronômico, em Campinas, a usina "Esther", no núcleo "Campos Sales”, voltando, via Rio Claro, para a Piracicaba.(Botelho, 1907, p7).

Até hoje com a facilidade de transportes que temos, esta viagem de estudos seria muito difícil.

O ano letivo de 1907 inicia com 60 alunos matriculados no primeiro ano, o que significa sucesso e credibilidade. Fora contratado mais um professor na Bélgica, o Sr. Jean Michel. Carlos Botelho (1908), responde aos que os criticavam por contratar tantos profissionais no estrangeiro, que as práticas que pretendia implantar eram feitas tal qual no estrangeiro, daí a necessidade de se importar os intelectuais e que, muitos dos adidos a esse pessoal em futuro próximo estarão “formando o manancial de funcionários necessários aos novos empreendimentos da administração” (Botelho, 1908, p. XII).

Na Fazenda Modelo, todos os trabalhos agrícolas tiveram em mira “incutir nos alunos, especialmente, os critérios racionais a seguir no emprego das máquinas $e$ aparelhos, e bem assim no uso das diversas espécies de fertilizantes” (Botelho, 1908, p.12). E finalmente fora implantado um curso prático de horticultura, independente do diretor da Fazenda Modelo.

Em linhas gerais, pode-se dizer que estas foram as principais realizações do Governo Jorge Tibiriçá, em relação ao ensino agrícola. Um projeto vultuoso, certamente. Cumpre ressaltar que havia ainda mais duas escolas agrícolas, a de Iguape e a de São Sebastião, com parcos recursos, destinadas a facilitar o ensino elementar de práticas de agricultura aos filhos dos agricultores locais. Estes dois estabelecimentos de ensino 
também serão modelos para outras que venham a se criar na "proporção que a Escola de Piracicaba for formando pessoal idôneo para dirigi-los” (Botelho, 1908, p.XII).

\subsubsection{O projeto de modernização da agricultura expresso em arte.}

As reformas pretendidas na agricultura foram expressas de formas pictóricas nos quadros, vitrais e murais comemorativos dos formandos em seus respectivos anos. Imagens que estão expostas no prédio central da ESALQ. No Salão Nobre encontramos um quadro notável que retrata a maior riqueza do Estado naquela época, a exportação de café (Figura 1).

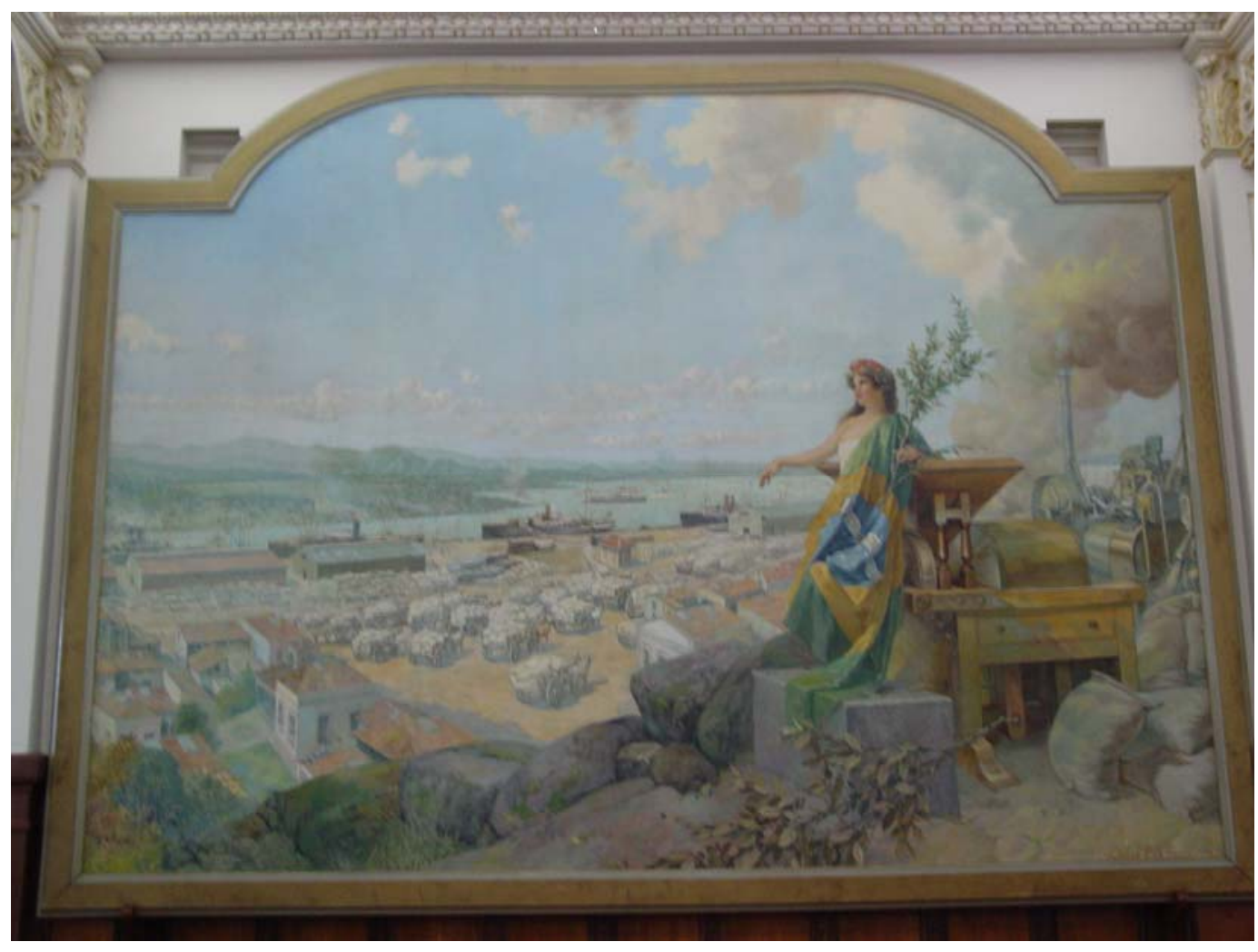

Figura 1 - A Exportação de Café no Porto de Santos 
Através da Figura 2, que é um detalhamento do quadro anterior, pode-se ver melhor a ferrovia conduzindo o café até a beira do cais, os galpões de armazenagem, os estivadores; Ceres, a deusa da agricultura na mitologia grega com a bandeira do Brasil e um ramo com café nas mãos; mais atrás o maquinário de beneficiamento com a chaminé soltando fumaça, até bem pouco tempo, um símbolo de progresso.

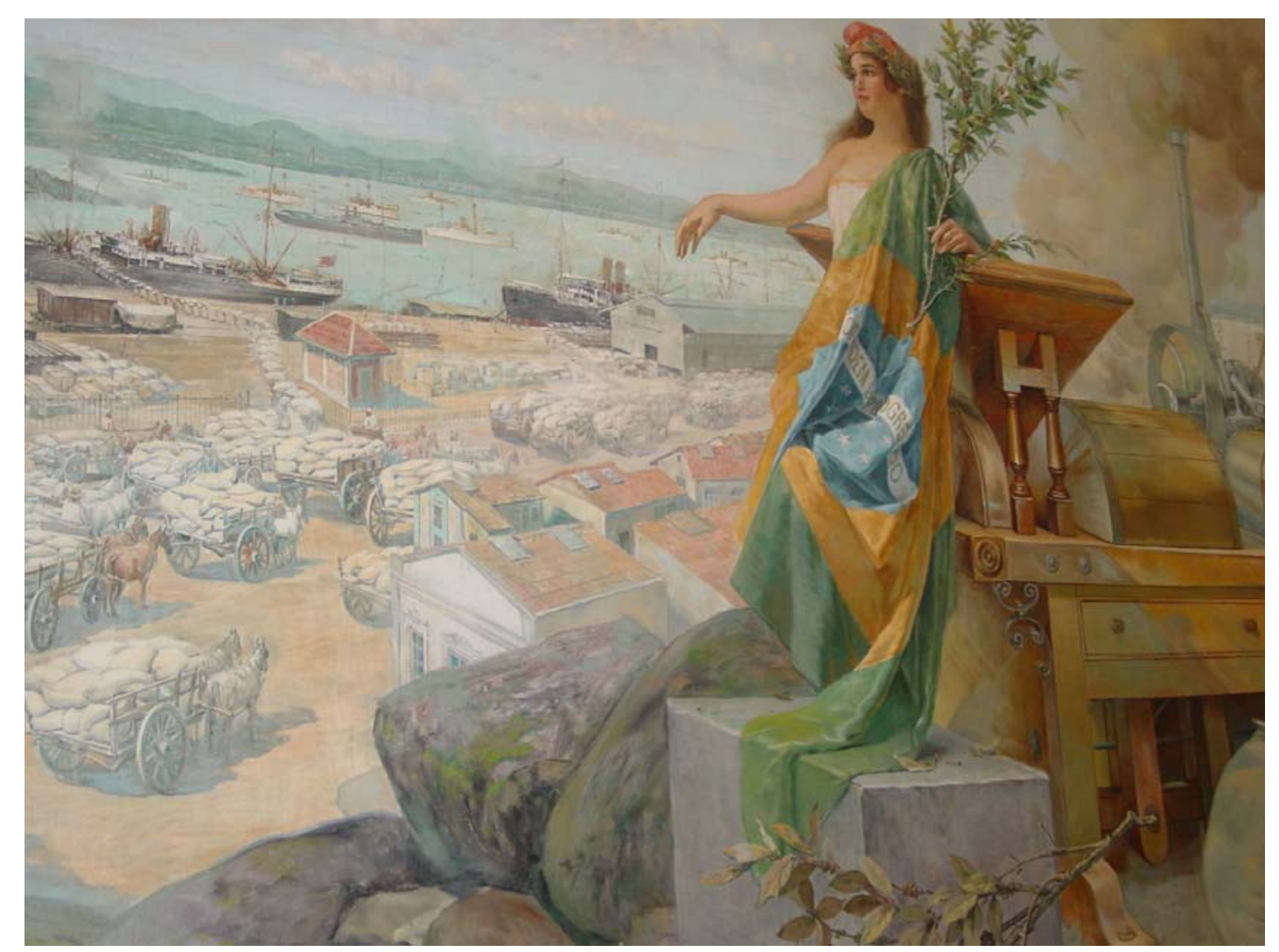

Figura 2 - O Porto de Santos e a intensa atividade de carregamento do café, por carroças e, principalmente, por ferrovia

No vitral da escada que conduz ao Salão Nobre da ESALQ está um quadro que remete a outro aspecto da modernização, a policultura: podemos observar a deusa Ceres segurando o que parece ser um feixe de trigo ou de arroz, o café, o coco, frutas, a abóbora, o gado. O prédio da ESALQ, a Fazenda Modelo, o Rio Piracicaba também fazem parte da paisagem. 


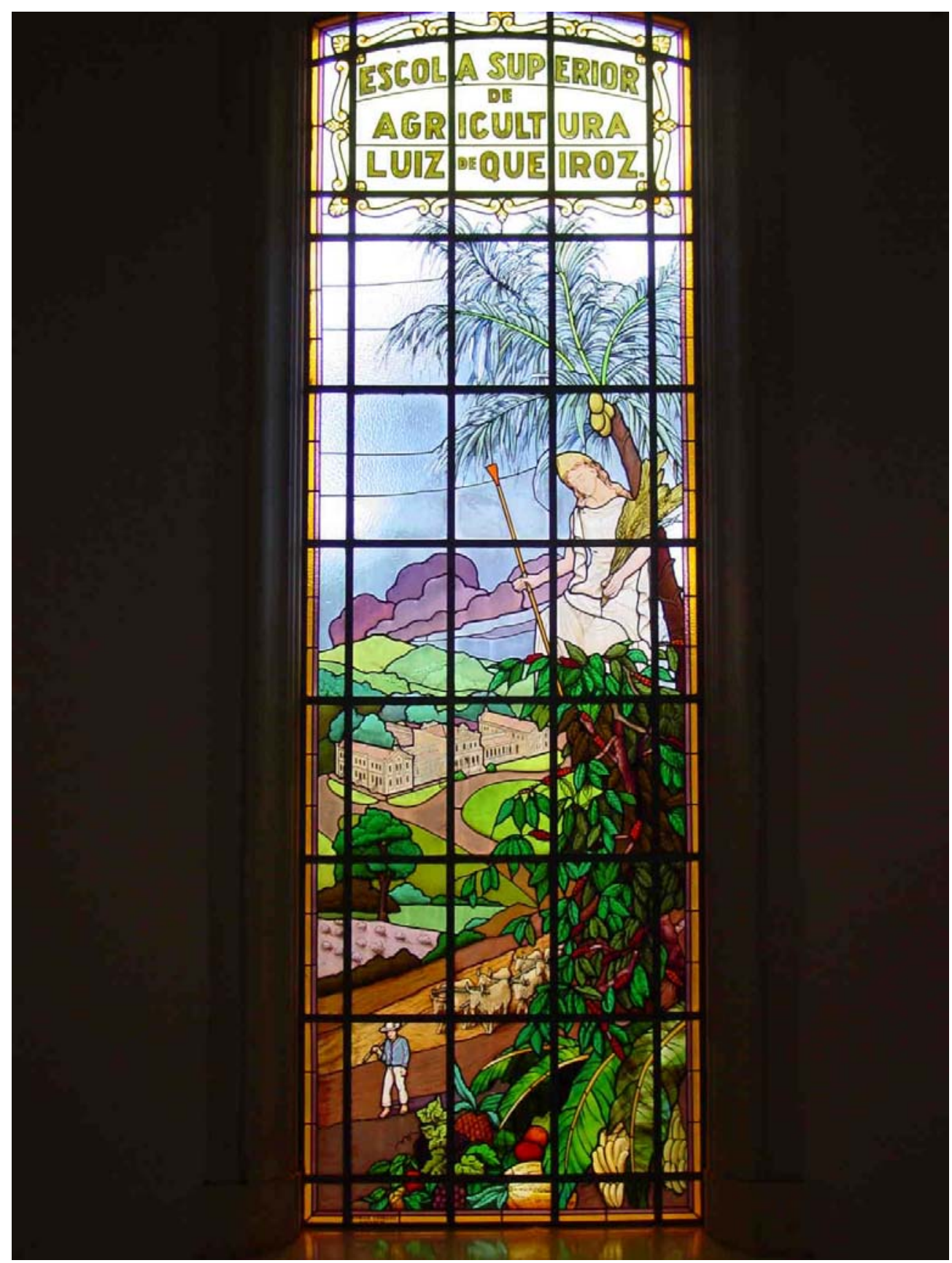

Figura 3 - Vitral localizado na escada que conduz ao Salão Nobre da ESALQ retratando os principais símbolos da agricultura da época 
As figuras subseqüentes referem-se ao aspecto mais visível da modernização que era o uso do maquinário. A Figura 4 é um detalhe do mural dos formandos de 1900. O arado retratado era na época o que hoje chamamos de tecnologia de ponta.

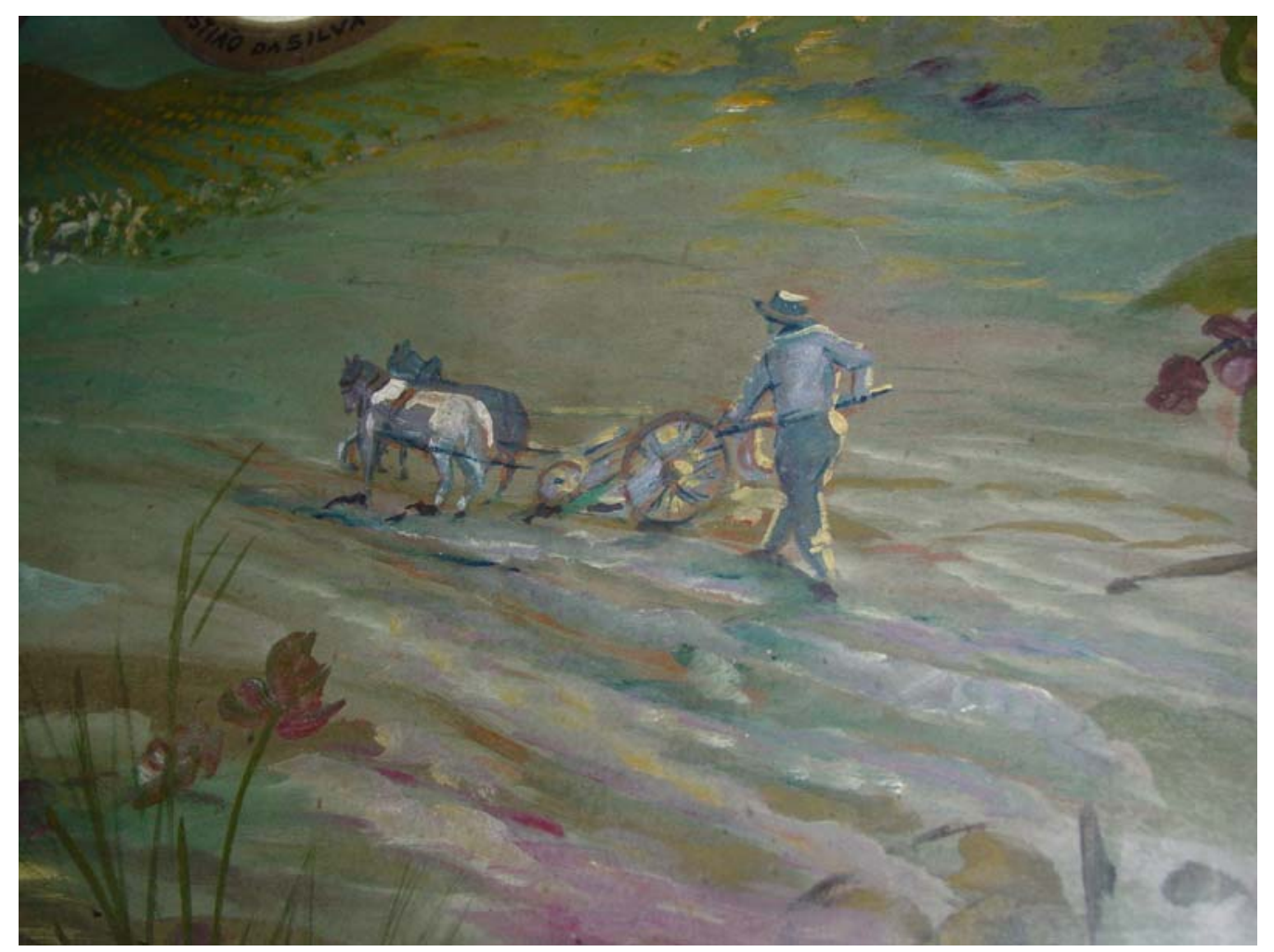

Figura 4 - Mural dos formandos de 1910 (Detalhe)

Na Figura 5 destaca-se o retrato de uma semeadeira. Pode-se ver, também, material de laboratório mostrando a importância da ciência e o prédio da ESALQ. 


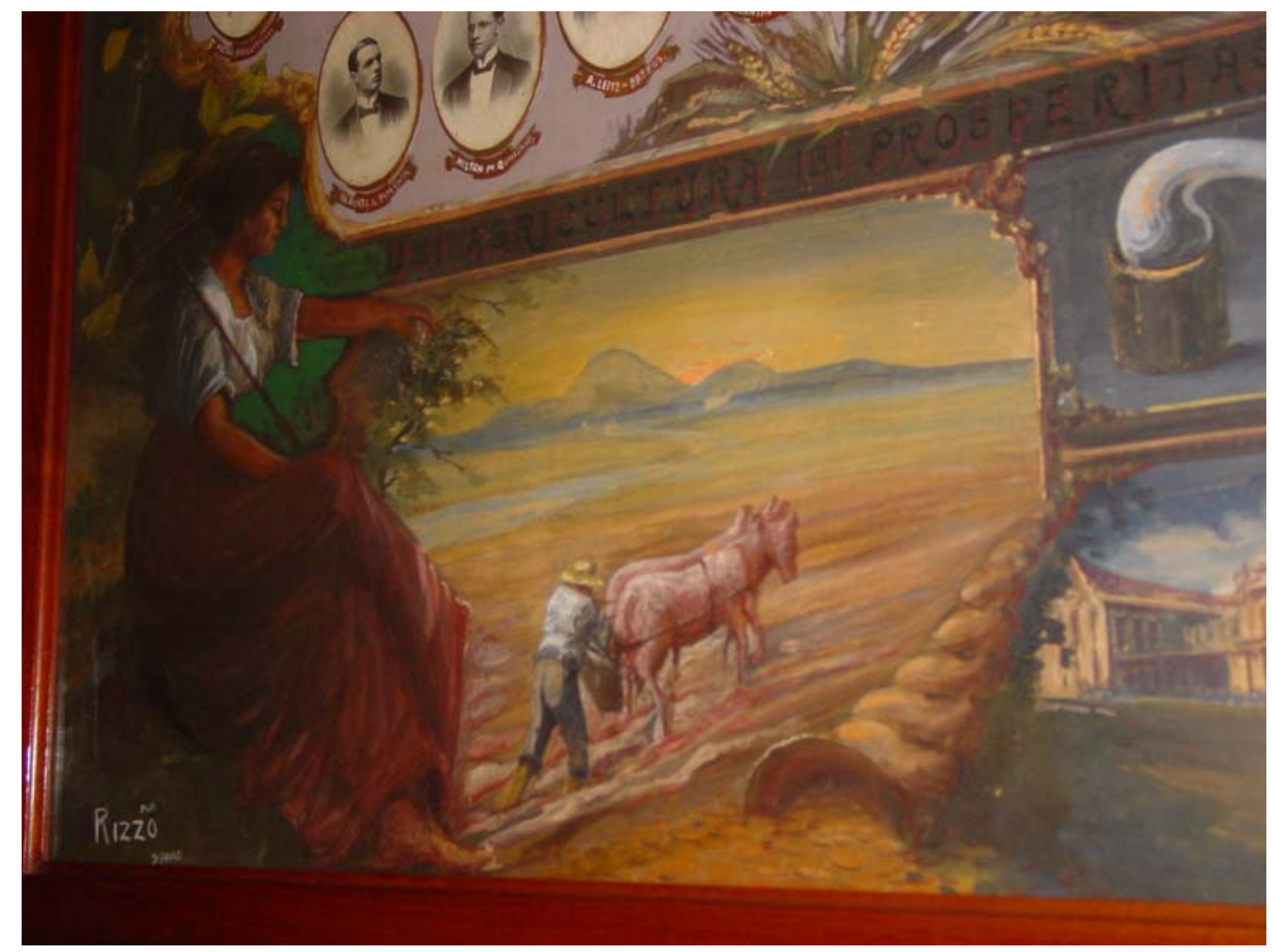

Figura 5 - Mural dos formandos de 1915

Na Figura 6 vemos o arado de disco, que desde o começo do século vinha sendo recomendado pela Revista Agrícola. 


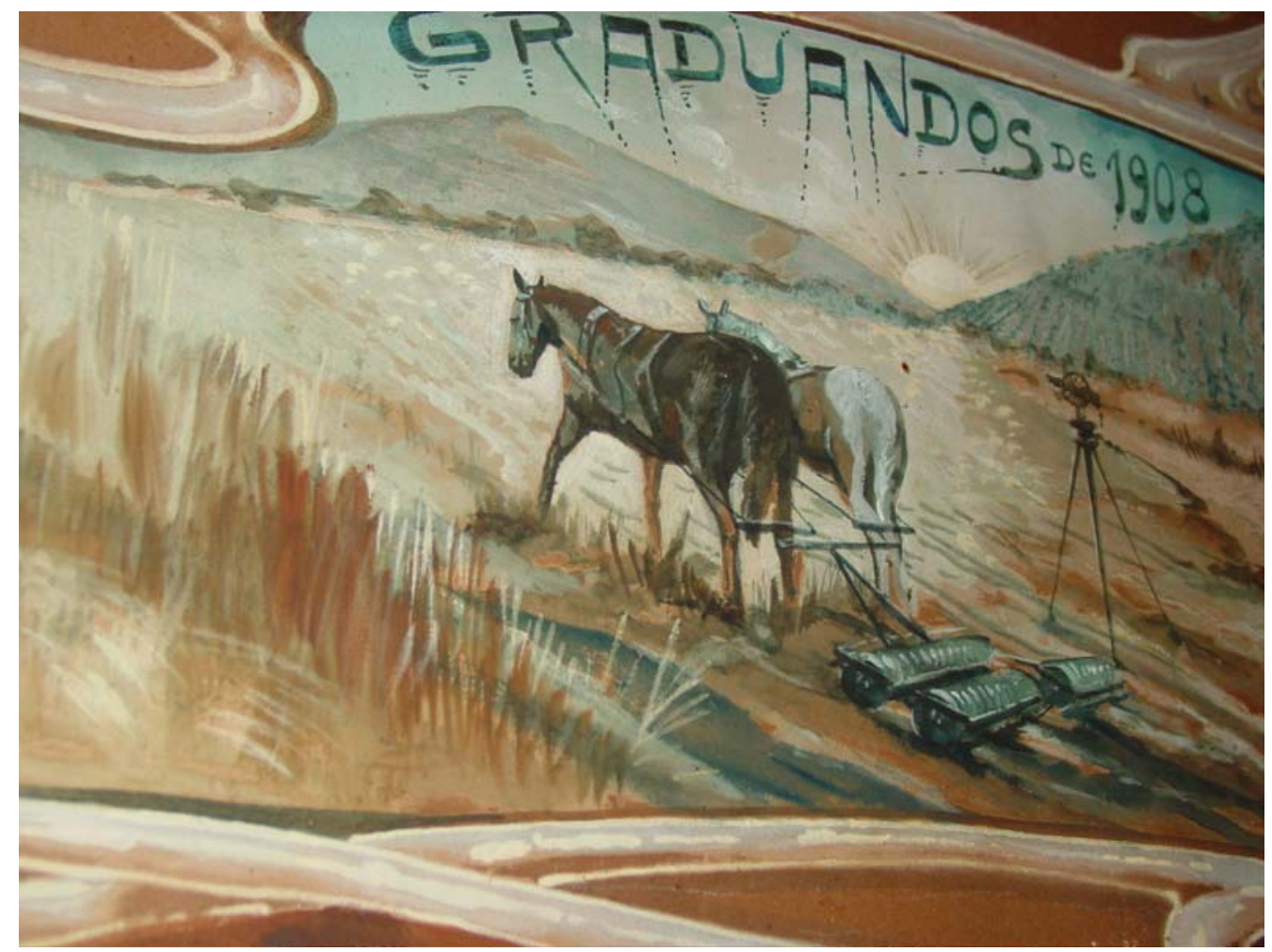

Figura 6 - Mural dos formandos de 1908

Nas duas figuras subseqüentes podemos observar a ESALQ vitoriosa, emitindo as luzes do saber e mostrando caminhos que estão iluminados. Ceres, os materiais de laboratório - simbolizando a ciência -, estão presentes, mas há um elemento novo, as moedas no solo junto aos frutos, o que dá um duplo sentido aos símbolos, tanto o solo pode ser riqueza, quanto os frutos, resultados do trabalho do homem. A presença da deusa grega Demeter, depois romanizada para Ceres, é pouco justificável, num mundo cristão, cujos símbolos centrais são o pão e o vinho, produtos derivados da agricultura, mas que também utiliza o óleo, a oliveira, o pombo, o peixe e o cordeiro. Então pode-se lançar duas perguntas: o que fazia com que homens imbuídos da ciência tivessem de recorrer a símbolos ligados à mitologia greco-romana? Por que não usar símbolos cristãos? 
A primeira pergunta fica sem resposta por que foge muito aos objetivos deste trabalho. Para respondê-la teríamos de fazer especulações filosóficas acerca da condição humana. Quanto à segunda indagação, podemos dizer duas coisas. Primeiro, que havia uma querela forte entre os republicanos e a igreja católica, pois os republicanos promoveram a separação entre igreja e estado. Segundo, porque grande parte dos intelectuais e políticos da Belle Époque eram positivistas e, portanto, ateus ou agnósticos.

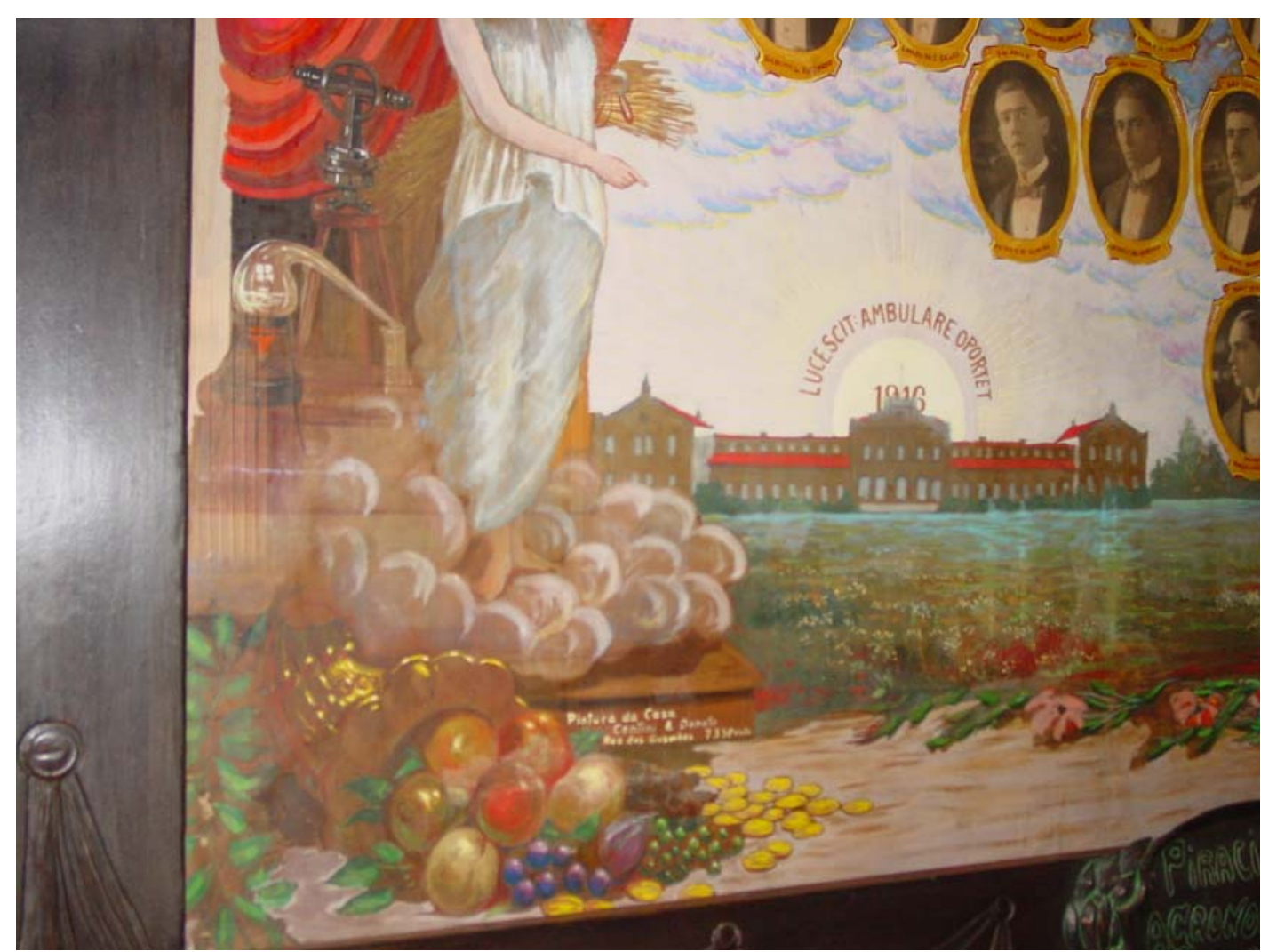

Figura 7 - Mural dos formandos da ESALQ de 1916 (Detalhe) 


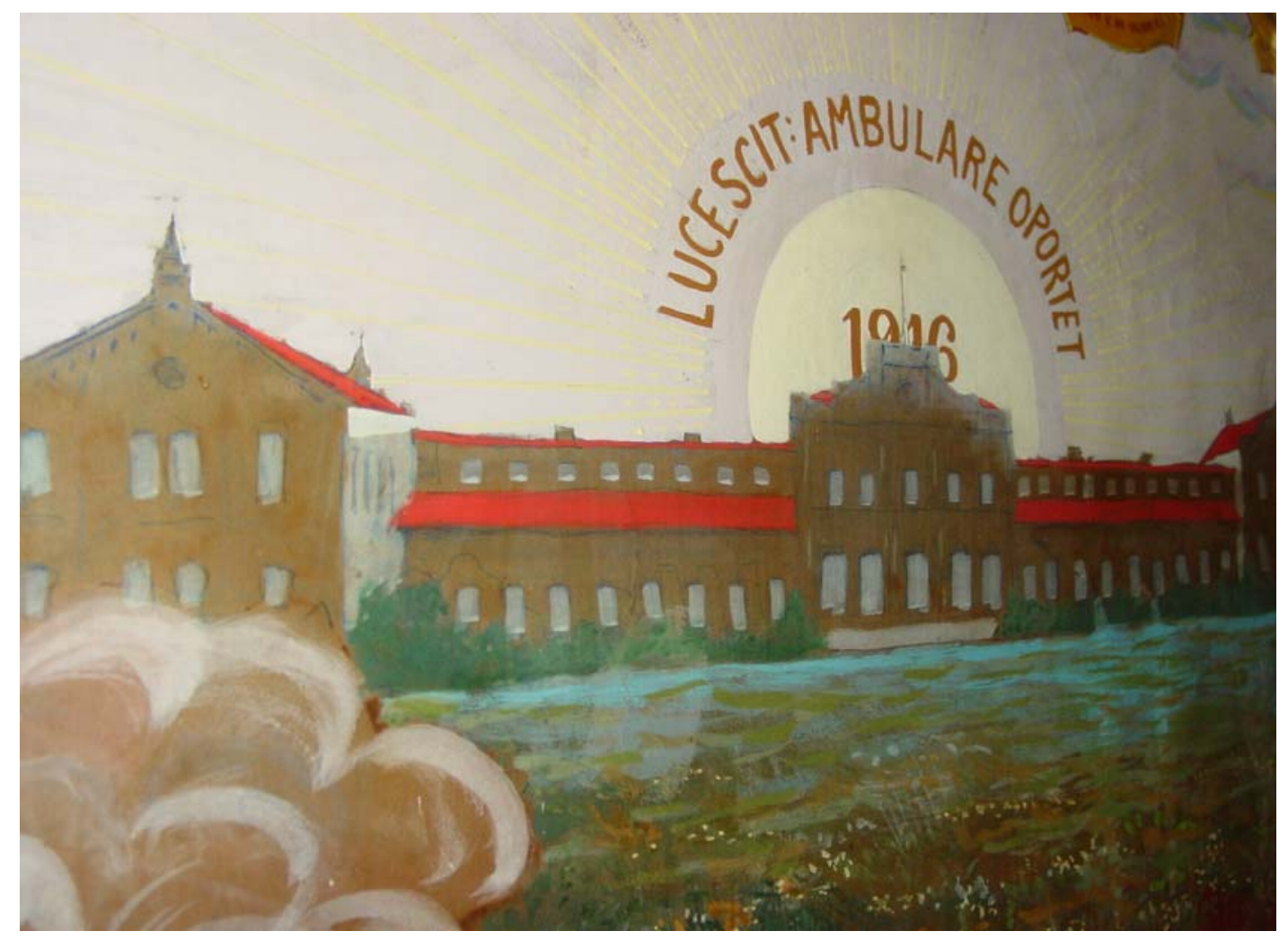

Figura 8 - Mural dos formandos da ESALQ de 1916 (Detalhe)

A confecção destes murais e sua preservação são indícios da importância que a ESALQ sempre atribuiu a sua missão de polo irradiador do ensino e da pesquisa na área da agronomia.

\subsection{A educação do cidadão para a nova agricultura.}

Uma vez estruturada a Escola Agrícola de Piracicaba e demais organismos de difusão de agricultura moderna, colocava-se um outro problema: como preparar o trabalhador para exercer as tarefas necessárias a este tipo de agricultura? C Botelho, no discurso aos formandos da Escola Agrícola de Piracicaba, em 1912, aconselhava aos moços morarem em suas fazendas, pois no seu entender o nosso trabalhador rural era incapaz de praticar a agricultura racional. "Tereis de criar, vós mesmos vossos 
operários.” (Botelho, 1912, p. 839). Mas como educar o homem trabalhador para as lidas da agricultura racional? É evidente que as três escolas existentes não seriam suficientes na realização de tal empreitada, sendo que outras medidas de maior alcance deveriam ser tomadas.

O trabalhador nacional vegetava na indolência e merecia reabilitação, mas não era um degenerado como as teorias racialistas faziam crer, mas sim um homem rude adequado às condições do meio hostil. Poderia ser recuperado, isto é, seu desenvolvimento físico e mental poderia ser promovido na medida em que o interesse e o amor ao trabalho fossem absorvidos via educação técnica.

Para Murari (2002), baseado em Sônia Regina Mendonça, as idéias mais recorrentes dentro dos programas de modernização do campo eram a necessidade de educar o homem do campo para o emprego de técnicas mais avançadas, para a superação da desordem e da indisciplina.

Vamos tentar delinear o projeto educacional mais amplo das elites do país no período, o que inclui a educação em seus aspectos formais e informais.

Na educação formal, livros didáticos contendo princípios da agricultura racional são editados e distribuídos. Em São Paulo, o Abc do Agricultor de Dias Martins, diretor e depois professor da Escola Prática de Agricultura Luiz de Queiroz, editado em 1908, chegou em 1930 à espantosa cifra de sessenta mil exemplares publicados. O fato de este livro ter atingido uma tiragem tão alta, mesmo para os padrões de hoje, indica que ele provavelmente era utilizado também pelas escolas do ensino regular.

Este manual pode ser considerado inovador para a época não somente em relação ao ensino agrícola, mas também em relação à educação em geral, pela sua preocupação com a eficiência do aprendizado. Era dividido em 12 capítulos, cada qual tratando de um assunto relativo à agricultura, ao solo, às doenças das plantas, aos animais, às noções de botânica, etc. Tinha também capítulos sobre higiene rural e saúde, ensinando como prevenir e combater doenças que atingiam os homens da zona rural. O objetivo explícito era ensinar o agricultor a adquirir confiança no seu ofício e ganhar dinheiro com mais facilidade e segurança que em qualquer lugar do país, auxiliando-o a tirar o máximo proveito de seu trabalho e de seu corpo. 
A primeira edição deste livro é de 1908, distribuídos não só em São Paulo, como em todo o país. Na primeira edição contava com 112 páginas e, na $5^{a}$, com mais de quatrocentas. O livro era composto de 12 lições sobre agricultura prática, higiene rural e até práticas socorristas na roça, onde percebemos claramente a influência do higienismo.

Seu método de ensino aprendizagem consistia em fazer com que:

“(...) por meio de pequenos resumos [o aluno fosse] aprendendo o mais essencial de cada capítulo, e de questionários, fazendo perguntas sobre assuntos dos mesmos capítulos e dando respostas respectivas nestas e naquela página de cada capítulo, habilita por esse modo o professor a saber como se deve perguntar $\boldsymbol{e}$ responder sobre este ou aquele assunto de cada uma das doze lições, e cada uma das lições não pode ser feitas sem ele mostrar aos alunos as cousas de cada lição e dizer-lhes em seu alcance para que elas servem, isto é, qual a sua utilidade, na natureza e principalmente na agricultura para melhorar a vida e o trabalho do agricultor.” (Martins, 1930, p.5).

O livro contava também com 48 figuras acompanhadas de todas as explicações de modo que o aluno pudesse “ver” o que está sendo ensinado: também induz o estudante a ver na agricultura, nos animais e na natureza as lições ensinadas e a ouvir do mestre para que elas servem. Portanto, aprende-se usando a razão e os sentidos: visão e audição.

Há também um capítulo destinado ao professor constituindo para ele um poderoso auxiliar, um verdadeiro.

"guia na coleta e no preparo das coisas dizendo respeito ao assunto de cada lição, ensinando-lhe o melhor modo de levar os alunos bem perto da natureza para vê-las aí entendê-las melhor quando o assunto assim exigir." (Martins, 1930, p.6)

Ou seja, o autor apresenta um capítulo com um guia de trabalho de campo, que deveria ser feito de maneira consistente, isto é, sempre ligado aos assuntos das lições tratadas.

O autor deixa claro que o livro não fora escrito somente para o ensino profissionalizante, mas para o professor primário poder utilizar duas vezes por semana em suas aulas para: 


\begin{abstract}
"por meio de visões de cousas da natureza e sugestões agradáveis aos olhos à curiosidade das crianças a escola primaria volta-lhe fortemente a inteligência para as coisas com as quais se pratica a agricultura, imprimindo-se assim com interesse na retina e inteligência com o fim especial de sugestioná-la agradavelmente para a vida de agricultor." (Martins, 1939, p.7-8)
\end{abstract}

Visualizar aquilo que está sendo ensinado, dar sugestões ao invés de imposições, aguçar a curiosidade, sugerir agradavelmente, fazer junto, aprender a fazer fazendo, estudar o meio, são os princípios decorrentes da Escola Nova, que ganhou força e adeptos com o Manifesto dos Pioneiros da Educação que é de 1930, mas já vinha sendo debatida no Brasil há muito tempo e foram incorporados pelo autor como forma de se facilitar a aprendizagem. Temos dúvidas, porém, se na primeira edição, a de 1908 já eram colocadas essas questões. Com certeza podemos afirmar que o aprender de forma prática era uma preocupação, na primeira edição, por que é uma decorrência lógica da noção de utilidade e praticidade, mas estava na edição de 1908 claramente ligada à noção de eficiência, e não é, certamente, uma pedagogia centrada no interesse do aluno, como seria se de fato fosse vinculada as teorias da Escola Nova. Podemos levantar a hipótese de que o autor estivesse procurando, com o prefácio da $5^{\mathrm{a}}$ edição mostrar que seu livro era compatível com as idéias pedagógicas em voga, ou seja, de que ele, e seu livro, estavam atualizados. Somente fazendo uma análise acurada do Abc do Agricultor, comparando-se as duas edições, para saber se realmente o autor incorporou elementos da Escola Nova.

O autor explicita que seu livro é destinado a todos:

"E nesse todo estão compreendidas também as crianças pobres, que em grande número são obrigadas a abandonarem a escola primária geralmente no fim de dois anos, porém, que assim, graças a este método de ensino terão também o caminho de suas vidas um pouquinho iluminados pela luz do sol da ciência, assim disseminada sob a forma de ensino popular, de utilidade imediata para se viver melhor, mesmo sabendo apenas o abc." (Martins, 1930, p.9-10).

Compete ainda observar uma diferença notável entre o ensino então praticado no Brasil e o ensino proposto pelos reformistas da educação. Segundo Libânio (1993), o 
ensino tradicional brasileiro sempre teve características bacharelescas ${ }^{31}$, com a finalidade de se formar profissionais liberais pouco afeitos ao trabalho braçal, sendo que a metodologia utilizada era a da memorização, o que exigia a imposição da disciplina, tendo inclusive o professor a licença para aplicar castigos. Esta é a primeira vez que encontramos referência a um modelo de ensino dirigido ao trabalhador, com capítulos redigidos numa linguagem acessível a todos, com ilustrações, com orientações práticas e demonstrações no próprio campo de trabalho e natureza, enfim fugindo totalmente dos penosos trabalhos de memorização, procurando tornar a aprendizagem mais fácil e agradável, para haver maior efetividade.

A esperança de Martins com a extensão deste projeto educacional era a de que o menino pobre que estudara até a segunda série fosse trabalhar ao lado do pai na fazenda, pudesse incorporar neste fazer o que aprendera estudando com o seu professor na escola primária, tornando-se assim um agricultor melhor que seus pais. Por ter consciência de que é muito difícil mudar hábitos arraigados, restava o apelo ao bolso, isto é, a ênfase na rentabilidade e lucros.

Martins apresenta os princípios que devem orientar a agricultura prática, que não sabemos também se estavam presentes na edição de 1908, mas que vamos transcrever porque neles é possível se perceber uma certa evolução na noção de agricultura prática. De qualquer forma são princípios subjacentes à modernização da agricultura ainda que não tenham sido fortemente explicitados na plataforma de Tibiriçá. Os precipícios são:

1- "Nada plantar para vender sem saber o mercado que compra e por quanto.

2- Nada cultivar ou criar para negócio sem saber quanto mais ou menos poderá gastar e ganhar.

3- Cuidar sempre e bem da lavoura e criação, porém cuidar muito mais e melhor do seu interesse.

4- Escrever e escriturar sempre diariamente o que se gasta para saber o que se tem.

\footnotetext{
${ }^{31}$ Para Monteiro Lobato, segundo Murari (2002), a atividade prática, técnica e científica era superior ao bacharelismo que combatia tão arduamente como um dos males que afligiam a nacionalidade.

Monteiro Lobato era um grande paladino da modernização do país e amigo de Navarro, sobre quem escreveu um capítulo do seu livro Onda Verde, no qual descreve com seu estilo peculiar os experimentos de Navarro para provar que o eucalipto era superior ao guarantã e encerrar de vez a polêmica J. Monlevade, seu colega engenheiro da Cia Paulista de Estradas de Ferro.
} 
5- Aprender agricultura no Brasil, para produzir barato $e$ vender bem com facilidade.

6- Em agricultura a melhor máquina é a mais útil e muito mais útil ainda é o bom senso do agricultor dirigindo o que é seu.

7- É muito útil ouvir os competentes, mas não se esquecer que em agricultura não há opinião mais valiosa do que a opinião da planta ou do animal explorados dentro do bolso do dono. (Martins, 1930, p.10-11).

Em 1915, Martins no prefácio do seu livro A Produção de Nossas Terras retoma a discussão a respeito da qualidade do ensino agrícola desenvolvida em seus então dezoito anos de agricultura no Oeste Paulista:

"Para se ter pessoal capaz de fazer o que se deseja que seja feito e como, é absolutamente indispensável prepará-lo também fazendo afim de que ele veja fazer, e repita fazendo o programa a executar, em vez de recebê-lo em regulamentos $e$ ofícios.” (Martins, 1914, p.10).

Em 1898 fora publicada a primeira edição do livro A Cultura dos Campos de Assis Brasil. Livro muito interessante no qual o autor defende que os campos devam ser também ocupados com lavouras de grãos, e não apenas terras com matas virgens, principalmente no Rio Grande do Sul, de onde ele era natural. Ensina técnicas modernas de plantio de cereais e leguminosas com a finalidade se substituir com vantagem as grandes importações que o Brasil então realizava, inclusive de milho. Faz um estudo acurado de todas as culturas possíveis de serem plantadas no centro-sul do Brasil.

É importante ressaltar que a terceira edição de A Cultura dos Campos fora distribuída nas escolas primárias mineiras durante o Governo de João Pinheiro, que foi um grande incentivador da agricultura em Minas Gerais. Ao que tudo indica é bastante provável que a obra tivesse tido algum tipo de influência sobre o manual de Dias Martins.

No campo da educação informal temos algumas iniciativas que merecessem ser apontadas: A primeira delas se refere aos Campos de Demonstração de Culturas, criados por Carlos Botelho e que deveriam "ser destinados a certas e determinadas culturas, 
nas zonas ou localidades do estado, que ofereçam maiores possibilidades de poderem adotar as mesmas culturas.” (Botelho, 1908, p. XIII)

Para facilitar a visita dos lavradores na época da colheita a estes campos, ofereciam-se passagens gratuitas pela ferrovia, porém antes do embarque, em São Paulo, eram feitas conferências sobre o assunto e somente depois que os lavradores iriam visitar as culturas de arroz.

O governo federal a partir de 1915, como Dias Martins ocupando cargo no Ministério da Agricultura, Indústria e Comércio também assume uma postura favorável à agricultura moderna. Primeiro procede a um diagnóstico da situação agrícola do país organizando um questionário que foi aplicado em dezessete estados, todos publicados, porém a sua proposta educacional modernizadora ainda era limitada em relação ao que ocorria no Estado de São Paulo. Pretendiam apenas implantar nas fazendas mais prósperas campos de demonstração de culturas, a serem organizados por funcionários capacitados no Rio de Janeiro. As fazendas escolhidas para instalação de campos de demonstração seriam aquelas de propriedade de homens considerados "exemplos vitoriosos, (...) homens de vontade” (Martins, 1915, p.8) onde seriam ensinados novos métodos aos agricultores, seus empregados e seus vizinhos. Os bons colonos, “aqueles disciplinados pela educação do trabalho das raças superiores” (Martins, 1915, p. 8) seriam considerados educadores por que ensinariam sem querer.

A Galeria de Demonstração das Máquinas em operação além do caráter propagandístico comercial tinha também uma função educativa, pois além de ressaltar as vantagens do maquinário, ensinava o agricultor a operá-los de maneira correta e eficiente. Foram realizados também cursos para condutores de máquinas agrícolas e sobre a extinção de formigas.

Havia também as exposições agrícolas e as pecuárias, como as de São C, Pindamonhangaba, Batatais e Itapetininga. Sem falar na grande exposição estadual de animais realizada em São Paulo, capital, em 1905, que teve grande sucesso e se repetiria nos anos seguinte. Tem se realizado ao logo de seu governo também exposições de Vacas leiteiras e um concurso de "Demonstração do fabrico de Manteiga, distribuindo pela maior quantidade de leite contido no mesmo e de gordura contida no mesmo" 
(Botelho, 1907, p.XVII). Estas práticas eram educativas porque tinham por objetivo colocar diante do fazendeiro novas possibilidades de aumentar a qualidade de seus rebanhos e de ensinar-lhes novas práticas de manejo.

Em São Paulo, segundo Botelho (1908), fazendo um balanço das realizações total de seu governo, foi criada a Biblioteca da Secretaria da Agricultura franqueada para consulta de profissionais, lavradores, funcionários e quaisquer outros interessados. Os serviços de distribuição de publicações da Secretaria da Agricultura sofrera uma remodelação e crescera muito em número de publicações. O Boletim da Agricultura mudou sua linha editorial, passando a valorizar a agricultura científica. Foram criados também o Boletim do Instituto Agronômico, o Boletim do Criador Paulista e concedidas subvenções a algumas publicações e revistas agrícolas e adquiridos o direito de autor de diversas publicações para formar a Biblioteca do Agricultor Paulista. O objetivo era a difusão do ensino agrícola.

Havia também uma difusão da agricultura moderna na mídia, em Revistas especializadas, tais como, a Revista Agrícola e, posteriormente, O Fazendeiro. Os jornais da época também faziam difusão destes princípios. Principalmente o Correio Paulistano e O Estado de São Paulo.

Por último não podemos deixar de citar a literatura. Os novos tempos estimulam novas sensibilidades e as tendências modernizantes se incorporam às obras literárias. Os romances mais significativos são o Canaã, de Graça Aranha e a obra de Monteiro Lobato, no qual ele relata a decadência do Vale do Paraíba.

Como conclusão do capítulo podemos apontar nossa dificuldade, a partir das fontes estudadas, de detectar a existência de um modelo educacional para formar um homem apto a trabalhar nas fazendas com a agricultura científica. Podemos sentir a necessidade dele de um modo indireto, através das queixas e de falas como a de Botelho, citadas na abertura deste tópico, aconselhando os lavradores a criarem seus operários. O manual escolar de Dias Martins é a única e notável exceção, embora os cursos para condutores de máquinas agrícolas e sobre a extinção de formigas também estivessem nesta linha, não dispomos de elementos para avaliar sua dimensão e alcance. 


\section{CONCLUSÕES}

Quais são as origens da moderna silvicultura tal qual a conhecemos hoje no Brasil? Ela surge para atender quais anseios? É consenso que ela nasce com Edmundo Navarro de Andrade e suas experiências com eucaliptos nos hortos da Companhia Paulista de Estradas de Ferro. Porém, é preciso um certo cuidado ao se pensar o processo histórico, e não atribuir somente a Navarro uma tarefa que não é individual dele, mas coletiva, mesmo mundial, conforme demonstrado anteriormente. Trata-se de um projeto de uma classe social, a burguesia cafeeira, que vai se gestando aos poucos. Recuperar este processo como um todo se fez necessário para entender um pouco da silvicultura praticada no país.

Procuramos demonstrar, ao longo desta pesquisa, que a questão mais relevante do período da Belle Époque, mais especificamente no início do século XX, refere-se ao processo de modernização da agricultura entendida como um projeto coletivo do grande capital cafeeiro que, com a crise de superprodução da lavoura de café, buscava alternativas de sobrevivência.

Após a viagem de Luiz Pereira Barreto aos Estados Unidos em 1901 e de Carlos Botelho em 1903, engajam-se num projeto de modernização da agricultura tendo aquele país como modelo, que vai sendo aos poucos desenvolvido na Sociedade Paulista de Agricultura (SPA) e na Revista Agrícola, que cumpre o papel de divulgação e de proporcionar a aglutinação de pessoas em torno dele.

As principais características do projeto de modernização da agricultura são: o uso de princípios científicos e tecnologia na organização do trabalho agrícola; a diversificação da agricultura, desenvolvendo novos cultivos adequados a áreas onde o 
café não se adaptava; a implantação de colônias de um novo tipo que fixaria o colono à terra, tornando-os pequenos proprietários, possibilitando um novo tipo de relações trabalhistas no campo, na qual o fazendeiro se eximiria da sua responsabilidade sobre o trabalhador em épocas em que não haveria trabalho no campo; a pesquisa agrícola também assumia um papel relevante porque novos conhecimentos deveriam ser estimulados e, na mesma medida, conhecimentos produzidos no estrangeiro precisavam ser adaptados a nossa realidade; o ensino agrícola era outro aspecto crucial do projeto, pois as novas tecnologias precisavam ser absorvidas pelo conjunto da sociedade. $\mathrm{O}$ modelo a ser seguido seria o norte-americano.

Em 1904, a SPA chega ao poder com a eleição de seu associado Jorge Tibiriçá, que nomeia Carlos Botelho para a Secretaria da Agricultura, que se encarrega de transformar a modernização da agricultura em política do Estado. É a primeira vez que a ciência se torna política pública no país em se tratando de agricultura, o que significa que se começa a dar um tratamento mais sistemático e eficiente a questões referentes à nacionalidade.

Há que se notar a imensa coerência do governo Tibiriçá perante seu programa, seus compromissos políticos e suas realizações. Implantou escolas agrícolas em todos os níveis, centros experimentais, buscou professores e técnicos no exterior. Procurou diversificar a agricultura, facilitar a importação de maquinário agrícola. Criou colônias de povoamento, substituiu importações de produtos agrícolas. Em suma todas as suas ações se fizeram no sentido de concretizar aquele programa.

Sabe-se que no Brasil se faz pouca história da ciência e recuperar um dos seus aspectos - a gênese de sua implantação na agricultura - nos pareceu de suma importância. Cremos abrir perspectivas para o estudo de outras instituições que participaram deste processo, tais como, o IAC, o Horto Botânico, depois Florestal, Horto Agrário de Cubatão, a Escola Superior de Agricultura Jorge Tibiriçá, em São Sebastião, o Aprendizado Agrícola Bernardino de Campos, em Iguape. A agricultura científica poderá ser analisada sob outros enfoques, tendo por exemplo, como de partida o 
fordismo e o taylorismo, novos paradigmas que em breve iriam começar a marcar sua influência no processo produtivo.

Nesta pesquisa procuramos demonstrar que aquilo que o senso comum chama de agricultura moderna - aquela que usa altas quantidades de adubos e defensivos agrícolas e maquinário ultra-sofisticado produzindo uma única cultura em larga escala, geralmente destinada à exportação, que tem seu início em meados dos anos sessenta do século XX -, na realidade não está em oposição àquela que usa como adubo apenas a estrumação ou a adubação verde e como instrumentos agrícolas apenas máquinas simples movidas à tração animal (arados, gradeadores, semeadores e colheitadeiras) que começa a ser praticada no início do mesmo século. São partes integrantes de um mesmo processo, porém em graus diferentes. Neste caso há uma confusão entre moderno e primitivo e entre moderno e obsoleto.

A modernização do início do século XX é considerada primitiva em função dos avanços da ciência e da tecnologia, que tornaram possíveis muitos progressos perante os quais os maquinários e as técnicas do período anterior tonaram-se obsoletas. Porém, o fato de serem obsoletos não quer dizer que sejam tradicionais, significa apenas que existem versões mais evoluídas, mas que não diferem em sua essência.

Historicamente, o moderno se apresenta como sendo oposição ou como aperfeiçoamento do tradicional. E em nossas pesquisas ficou claro que tradicional era a agricultura praticada no Brasil desde o descobrimento com forte influência dos brasileiros nativos e afro-descentes. Era toda baseada no trabalho escravo, no corte da mata, queima, coivaras, semeadura, capina, colheita, enfim todas as operações do processo produtivo eram realizadas usando apenas o trabalho braçal, os instrumentos como sendo o machado, a enxada e a foice, tendo o fogo como principal aliado. Sua principal característica estava no fato de ser itinerantes: usava-se o solo até o seu completo desgaste que depois era abandonado completamente até que ele se recuperasse naturalmente pela recomposição da vegetação.

É importante citar ainda a grande confusão entre as concepções de agricultura tradicional com as idéias de agricultura de subsistência ou agricultura familiar. A grande 
agricultura de exportação, até o início do século XX, organizava-se também nos moldes da agricultura tradicional enquanto que, mesmo naquela época, pequenos proprietários que produziam para o mercado, notadamente imigrantes, também possuíam instrumentos agrícolas e usavam práticas modernas, apesar de muitas vezes usarem apenas o trabalho familiar.

Achamos relevante desenvolver estes conceitos de agricultura tradicional e de agricultura moderna para mostrar aos interessados no assunto que ela é uma construção social, historicamente definida de acordo com as necessidades impostas pelo tempo. Se a agricultura tradicional nos serviu durante cerca de trezentos anos, chegou um momento que em que ela não era mais suficiente e houve a necessidade de se articular uma mudança social que tornasse possível um novo tipo de agricultura totalmente diferente do até então praticado.

A agricultura tradicional, no entanto, parece ter caído no esquecimento, como se o tipo mais remoto de agricultura praticado no Brasil fosse aquele do arado puxado a burro. É importante perceber que a história muda de acordo com a vontade coletiva dos homens, que a mudança é possível e que a medida que a agricultura que é praticada hoje não se fizer mais satisfatória, será possível a criação de um novo tipo.

Outra questão que consideramos de suma relevância diz respeito ao fato de que propor mudanças radicais na agricultura no Brasil de então, uma nação essencialmente agrícola, significava mudar a própria face do país. Decerto que as mudanças vinham ocorrendo desde o fim da escravidão e da proclamação da República, porém, no momento em que atingiram os processos de produção agrícola envolveriam um número muito maior de pessoas sendo, portanto, muito mais significativa.

Mudar a agricultura implicava na construção de um novo saber agrícola e na assimilação desse saber pela população, tanto pelos grandes fazendeiros, quanto pelo modesto trabalhador. O primeiro para definir os rumos de suas propriedades, o segundo para poder lidar com novos saberes e novas tecnologias. Urgia então a criação de centros de pesquisas e de escolas agrícolas e assim foi feito. A ESALQ fora criada como a escola de referência e revoluciona o ensino agrícola ao trazer o ensino prático, de 
características tão diferentes daquele ensino bacharelesco que outrora se praticava e ainda se pratica no país. Torna-se uma referência não só no Estado de São Paulo, mas no país.

Dentro do quadro de modernização surge a necessidade de uma nova silvicultura que suprisse as ferrovias no abastecimento de lenha para as locomotivas e que ajudasse a preservar as matas nas regiões por elas atravessadas. A Cia Paulista de Estradas de Ferro assume a vanguarda deste processo e cria imensos bosques de eucaliptos dentro dos mais avançados processos da silvicultura racional. Projeto este que já nasce moderno na acepção que temos utilizado até aqui.

Navarro de Andrade é o grande realizador deste processo, tornando-se quase um ícone. Consegue fazer com que a silvicultura por ele implantada, inspirada em modelos europeus e, sobretudo norte-americanos, se espalhe pelo país e se torne praticamente o único modelo de silvicultura existente, ao ponto de merecer um busto de bronze em frente ao Departamento de Ciências Florestais da ESALQ, coisa que nem Carlos Botelho, seu grande reformador e ideólogo tem.

O encantamento geral despertado pela figura de Navarro reside no fato dele ter levado a noção de eficiência até as últimas conseqüências atingindo índices de produtividade que decorridos trinta anos depois de suas primeiras pesquisas ainda não haviam sido superados.

Entretanto, como conservacionista, podemos quando muito argumentar que nem mesmo na Companhia Paulista de Estradas de Ferro a sua empreitada fora satisfatória, pois ela nunca conseguira produzir mais de quarenta por cento da lenha que consumia, ou seja, mesmo com um "mar de eucaliptos", ainda continuava consumindo árvores e florestas naturais inteiras. Entendemos que o seu liberalismo e utilitarismo radicais, bem como os compromissos diretos com a classe empresarial para o qual trabalhava o impediam de ir mais longe e tomar atitudes mais radicais no sentido da conservação da natureza. 
Enfim, esperamos ter mostrado que a modernização da agricultura é um processo mundial, que o Brasil nela se insere elegendo a Europa como modelo intelectual e os Estados Unidos como exemplo concreto a ser imitado em suas realizações, sendo a SPA sua principal mentora intelectual no Estado de São Paulo e o Governo de Jorge Tibiriçá (1905-1908) seu primeiro implementador. Navarro se insere neste processo desde a sua chegada ao Brasil, em 1903, produzindo conhecimento de natureza teórico-prático em diversos ramos da agricultura moderna, mas se sobressai ao implantar nos Hortos da Cia Paulista de Estradas de Ferro uma silvicultura fortemente calcada nos princípios da agricultura moderna. 


\section{REFERÊNCIAS BIBLIOGRÁFICAS}

ANDRADE, E. N. de. Escola Nacional de Agricultura de Coimbra. Revista Agrícola, v.IX, n.101, p.492-496, dez. 1903a.

ANDRADE, E. N. de. Instrumentos de poda. Revista Agrícola, v. IX, n.96, p.286-289, jun. 1903b.

ANDRADE, E. N. de. Podas. Revista Agrícola, v.n.100, p.448-452, nov. 1903b.

ANDRADE, E. N. de. Terrenos de viveiro. Revista Agrícola,v.IX, n.100, p.140-141, mar.1904.

ANDRADE, E. N. de. A cultura do eucalyptus nos Estados Unidos. São Paulo: Typ. Brazil de Rothschild, 1910. 130p.

ANDRADE, E. N. de. A importância das matas. O Fazendeiro, v.4, n.10, p. 471-475, out. 1911a.

ANDRADE, E. N. de. Prados. O Fazendeiro, v.4, n.3, p.88-89, mar. 1911 b.

ANDRADE, E. N. de. Utilidade das florestas. São Paulo: Typ. Alongi, 1912a. 104p.

ANDRADE, E. N. de. Influência das florestas sobre as nascentes, os cursos d'água e os terrenos de montanha. Boletim Agrícola, n.3, p.258-268, 1912b. 
ANDRADE, E. N. de. Madeiras nacionais. O Fazendeiro, v.5,. n.3, p.80-83, mar. 1912c.

ANDRADE, E. N. de. Resumo dos trabalhos executados no primeiro semestre de de1912. Boletim Agrícola, n.6, p.512-514, 1912d.

ANDRADE, E. N. de. Extinção de formigas. O Fazendeiro, v.8, n.3, p. 147-149, mar. 1915a.

ANDRADE, E. N. de. Questões florestais. São Paulo: Typ. Messina Palottini, 1915b. $55 p$.

ANDRADE, Edmundo N. de. Les bois indigènes de São Paulo: contribuition a l'étud de la flore forestiere de L'etat de S. Paulo. São Paulo:[s.n.] 1916. 376p.

ANDRADE, E. N. de. O problema florestal no Brasil. São Paulo: Edições O Estado de São Paulo, 1923. 104p.

ANDRADE, E. N. de. Por, ahí além - impressões de viagem. São Paulo: Typ. Brazil de Rothschild, 1927. 156p.

ANDRADE, E. N. de. Contribuição para o Estudo da Entomologia Paulista. São Paulo: Secretaria da Agricultura, Indústria e Comércio do Estado de São Paulo, 1928. 10p.

ANDRADE, E. N. de. Formicidas. São Paulo: Secretaria da Agricultura Indústria e Comércio do Estado de São Paulo, 1929. 29p. 
ANDRADE, E. N. de. Pesquisas sobre a biologia da mosca da madeira Panto phitalmis pictus (Wied.1821). In: Instituto Biológico de Defesa Agrícola e Animal, Subsídios para a Entomologia Agrícola Brasileira (VIII). São Paulo: Editora Arquivos do Instituto Biológico de Defesa Agrícola e Animal, 1930. p.249-245

ANDRADE, E. N. de. O Problema do reflorestamento é vital para São Paulo. Chácaras e Quintaes, p.67-68, jan.1936.

ASSIS BRASIL, F. de. A cultura dos campos Paris: Mornier, Jeanbin, 1905. 351p.

BARRETO. L. P. O Brasil está em caminho de progresso com os Estados Unidos por modelo Industrial. Revista Agrícola, 70, p.176-178, mai. 1901.

BARRETO, L. P. Qual cultura pode substituir a do café? Revista Agrícola, n.79, p.7375, fev. 1902.

BARRETO, L. P. Congresso Agrícola. Revista Agrícola, n.79, p.47-51, fev. 1903a.

BARRETO, L. P. Higiene agrícola e economia rural. Revista Agrícola, .101, p.497-502, dez. 1903b.

BOTELHO, C. A colossal riqueza agrícola dos Estados Unidos da América do Norte. Revista Agrícola, n.70, p.264-267, jul. 1901.

BOTELHO, C. Relatório apresentado ao Dr. Jorge Tibiriçá presidente do estado pelo Dr. C Botelho, secretário da agricultura, ano 1904. São Paulo: Typographia Brazil de C Gerke, 1905.282p. 
BOTELHO, C. Relatório apresentado ao Dr. Jorge Tibiriçá presidente do estado pelo Dr. C Botelho, secretário da agricultura, ano 1905. São Paulo: Typographia Brazil de C Gerke, 1906. 273p.

BOTELHO, C. Relatório apresentado ao Dr. Jorge Tibiriçá presidente do estado pelo Dr. C Botelho, secretário da agricultura, ano 1906. São Paulo: Typographia Brazil de C Gerke, 1907. 351.p.

BOTELHO, C. Relatório apresentado ao Dr. Jorge Tibiriçá presidente do estado pelo Dr. C Botelho, secretário da agricultura, ano 1907. São Paulo: Typographia Brazil de C Gerke, 1907. 334p.

BOTELHO, C. Conferência do Dr. Carlos Botelho aos agromandos de 1912. Boletim da Agricultura, v. n.p.834-846, 1912.

CARDOSO, J. P. O progresso dos Estados Unidos e o novo arado de disco. Revista Agrícola, v.VII, n.82, p.252-257, jul. 1902.

CARMO, A. G. do. Considerações históricas sobre a agricultura no Brasil. Rio de Janeiro: Ministério da Agricultura: Serviço de Publicidade Agrícola, 1939. 39 p.

CASTRO, M. I. M. O preço do progresso: a construção da Estrada de Ferro Noroeste do Brasil. Campinas, 1993. 292p. Dissertação (M.S.) - Universidade Estadual de Campinas.

O FAZENDEIRO. Manual do plantador de eucaliptus, São Paulo, v.4, n.8/9, p.456, ago/set 1911 .

O FAZENDEIRO. A derrubada das florestas. São Paulo, v.6,n.7, p.256-257, jul. 1913. 
O FAZENDEIRO. Transportes nas fazendas: uma útil invenção. v.7, n.3 p.157, mai. 1914.

O FAZENDEIRO. Rendimento das plantações florestais. São Paulo, v.8, n.6, p.191192, jul. 1915.

O FAZENDEIRO. Les bois indigènes de São Paulo: contribuition a l'étud de la flore forestiere de L'etat de S. Paulo. São Paulo, v.9, n.12, p.270-273. dez.1916.

O FAZENDEIRO. A plantadora. São Paulo, v.10,.n.3,. p.63, mar. 1917.

O FAZENDEIRO. Serviço Florestal. São Paulo, v14,.n.7,. p.149, jul. 1921a.

O FAZENDEIRO. As madeiras do Estado de São Paulo. São Paulo, v.14, n.12, p.270273, dez. 1921b.

GRANATO, L. Breves instruções para a cultura do eucaliptus. Revista Agrícola, v.XII, n.140/141, p.125-133, mar./abr.1907.

KOSCINSKI, M. Algo sobre a bracatinga. São Paulo: Secretaria da Agricultura, Indústria e Comércio do Estado de São Paulo, 1934. 29p.

LEME, P. G. P. A propósito das derribadas. Revista Agrícola, v.VI, n.56, p.80-85, mar. 1900.

LESSA, S. N. Trem de ferro: do cosmopolitismo ao sertão. Campinas, 1993. 243p. Dissertação (M.S.) - Universidade Estadual de Campinas.

LIBÂNIO, J. C. Democratização da escola pública. 11.ed. São Paulo: Edições Loyola, 1993. 149 p. 
LÖEFGREN, A.. Instruções para a cultura de eucalyptus. Boletim Agrícola, v n.8, p.370-374, ago. 1904.

MARTINS, D. Abc do agricultor. Rio de Janeiro: Papelaria Americana, 1930. 412 p.

MARTINS, D. A produção de nossas terras. Rio de Janeiro: Ministério da Agricultura, Indústria e Comércio, 1915. 215 p.

MARTINS, D. A escolha do sítio. O Fazendeiro, v.1, n.1, p.38-40, abr.1908.

MELLO, J. da Silva. Instrumentos agrícolas usados na América do Norte. Revista Agrícola, v.VII, n.79, p.85-90, fev. 1902.

MONBEING, P. Pioneiros e fazendeiros em São Paulo. São Paulo: Hucitec; Editora Polis, 1984. 392p.

MURARI, L. As concepções de sertão na literatura brasileira. São Paulo, 2002. 487p. Tese (Doutorado) - Faculdade de Filosofia Ciências e Letras, Universidade de São Paulo.

PERISSINOTTO, R. M. Classes dominantes e hegemonia na República Velha. Campinas: Editora da Unicamp, 1994. 251p.

PESTANA, P. R. A crise cafeeira. O Fazendeiro, v.1, n.4, p.85-86, jul. 1908.

PESTANA, P. R.. A expansão econômica do Estado de São Paulo: 1822-1922. São Paulo: Secretaria da Agricultura, Comércio e Obras Públicas do Estado de São Paulo,1923. 54p. 
REVISTA AGRÍCOLA. O novo governo de São Paulo. São Paulo, v.X, n.106, mai.1904a. p. 179-184.

REVISTA AGRÍCOLA. A vida americana. Indústria pastoril, agricultura e fábricas dos Estados Unidos. São Paulo, v.X, n. 06, mai. 1904b. p. 204.

REVISTA AGRÍCOLA. Dr. Carlos Botelho. São Paulo, v.X, n.106, mai.1904c. p. 196199.

REVISTA AGRÍCOLA.Concurso Regional do Segundo Distrito Agrícola de São Paulo. São Paulo, v.VI, n. jun.1900. p. 238.

SAES, F. A. M. A Grande empresa de serviços públicos na economia cafeeira: 18501930. São Paulo: Hucitec,1986. 248p.

SAMPAIO, A. N. Edmundo Navarro de Andrade, um pouco de sua vida e de sua obra. In: ANDRADE, E. N. de O Eucalipto. 2.ed. Jundiaí - SP: Companhia Paulista de Estradas de Ferro, data.230p..

SEGNINI, L. R. P. Ferrovias e ferroviários: uma contribuição para análise do poder disciplinar na empresa. São Paulo: Autores Associados; Cortez Editores. 1982. 103p.

SEVCENKO, N. Literatura como missão: tensões sociais e criação cultural na Primeira República. 2.ed. São Paulo: Companhia das Letras. 2003. 420 p.

SIXT, E. Distribuição de plantas do Serviço Florestal do Estado de São Paulo. O Fazendeiro, v.5, n.1, p.40-42, jan. 1912.

SOARES JUNIOR., R. Jorge Tibiriçá e sua época. São Paulo: Cia. Editora Nacional, 1958. 2v. 623p. 
VERT, G. Regulamento do Concurso Regional e Exposição Agrícola Revista Agrícola, v.VI, n. p.267-269, jul. 1900.

VERT, G. Mattas. Revista Agrícola, n.IX, v. n.99, p.429-422, nov. 1903. 